\begin{abstract}
UNIVERSIDADE DE SÃO PAULO
FACULDADE DE FILOSOFIA, LETRAS E CIÊNCIAS HUMANAS

DEPARTAMENTO DE LETRAS MODERNAS

PROGRAMA DE PÓS-GRADUAÇÃO EM ESTUDOS LINGUÍSTICOS E

LITERÁRIOS EM INGLÊS
\end{abstract}

MAURÍCIO DEMICHELLI

\title{
A guerra na Síria e a construção da soberania americana: uma análise discursiva da cobertura do The New York Times.
}

SÃO PAULO 


\title{
A guerra na Síria e a construção da soberania americana: uma análise discursiva da cobertura do The New York Times
}

\author{
Versão Original
}

Tese apresentada ao Programa de PósGraduação em Estudos Linguísticos e Literários em Inglês, do Departamento de Letras Modernas da Faculdade de Filosofia, Letras e Ciências Humanas da Universidade de São Paulo, para obtenção do título de Doutor em Letras.

Orientadora: Profa. Dra. Anna Maria G. Carmagnani

\section{SÃO PAULO}

2018 
Autorizo a reprodução e divulgação total ou parcial deste trabalho, por qualquer meio convencional ou eletrônico, para fins de estudo e pesquisa, desde que citada a fonte.

Catalogação na Publicação

Serviço de Biblioteca e Documentação

Faculdade de Filosofia, Letras e Ciências Humanas da Universidade de São Paulo

D378g A guerra na Síria e a construção da soberania americana: uma análise discursiva da cobertura do The New York Times / Maurício Demichelli ; orientadora Anna Maria G. Carmagnani. - São Paulo, 2018 .

$177 \mathrm{f}$.

Tese (Doutorado)- Faculdade de Filosofia, Letras e Ciências Humanas da Universidade de São Paulo. Departamento de Letras Modernas. Área de concentração: Estudos Linguísticos e Literários em Inglês.

1. Discurso Político. 2. Análise do Discurso. 3. Soberania. 4. Jornalismo. I. Carmagnani, Anna Maria G., orient. II. Título. 
Nome: DEMICHELLI, Maurício

Título: A Guerra na Síria e a construção da soberania americana: uma análise discursiva da cobertura do The New York Times

Tese apresentada ao Programa de PósGraduação em Estudos Lingüísticos e Literários em Inglês do Departamento de Letras Modernas da Faculdade de Filosofia, Letras e Ciências Humanas da Universidade de São Paulo, para a obtenção do título de Doutor em Letras.

Aprovado em:

Banca Examinadora

Prof.

Instituição:

Julgamento:

Prof.

Instituição:

Julgamento:

Prof.

Instituição:

Julgamento:

Prof.

Instituição:

Julgamento:

Prof.

Instituição:

Julgamento: 
A Deus, em sua infinita bondade, que me deu o dom da vida e a oportunidade de viver grandes momentos.

A minha mãe, Alice, e a meu pai, Armando (in memorian), que são, sem dúvida, o caminho e razão de todas as conquistas.

Ao meu irmão, Marcos, pelo amor, carinho e incentivo.

Ao meu companheiro, Breno Matos, por todo estímulo para que eu seguisse com meus projetos. 


\section{AGRADECIMENTOS}

À Professora Dra. Anna Maria Carmagnani, minha orientadora desde os tempos da graduação, pelo excepcional trabalho de orientação e por sua amizade em todo o meu trajeto acadêmico.

À Professora Dra. Deusa Maria de Souza Pinheiro Passos, pelo acolhimento no início dessa minha etapa.

Aos professores Carlos Renato Lopes e Mayra Rodrigues, pelas preciosas contribuições no meu exame de qualificação.

Aos amigos, Glaucia Fernandes, Luciano Magnoni Tocaia, Mayra Moura e Ronaldo de Oliveira Batista.

Ao amigo Adalto Moraes de Souza, pela amizade e primorosa revisão do texto.

Aos amigos da Universidade Presbiteriana Mackenzie, pelo incentivo e interesse em minha pesquisa, tornando-se interlocutores de algumas inquietações.

Ao Tico, por todo o carinho e amor incondicional.

A todas as vozes que, intencionalmente ou não, contribuíram para a realização dessa pesquisa. 


\section{RESUMO}

DEMICHELLI, Maurício. A guerra na Síria e a construção da soberania americana: uma análise discursiva da cobertura do The New York Times. 2018. Tese (Doutorado em Letras) - Faculdade de Filosofia Letras e Ciências Humanas, Universidade de São Paulo, São Paulo, 2018.

Este trabalho tem como objetivo estudar o discurso político americano do período inicial da guerra na Síria, visto pela perspectiva do jornal The New York Times. A partir de uma abordagem discursiva baseada principalmente em Foucault (1971), procuramos compreender de que forma a narração da guerra no jornal é constituída por valores culturais americanos que se transformam em uma episteme de compreensão do mundo, dos homens e da realidade.

Propomos um olhar para o corpus de análise que permita observar, primeiramente, como o sujeito que tem o direito à fala vai se constituindo e construindo seus objetos: a guerra e o inimigo. Em um segundo momento, baseado nas teorias sobre Império desenvolvidas por Hardt e Negri (2001) e nos estudos de Said (1993, 1999) sobre Orientalismo, observamos como o discurso sobre a guerra da Síria se constitui com base em um projeto ideológico expansionista americano, que se desenvolveu desde a constituição e consolidação da nação e que se encontra para além das fronteiras geográficas. Por fim, concentramos nossa análise no papel da mídia como produtora de um material simbólico, que, ao dar inteligibilidade à guerra, entra em consonância com o espírito americano, fortalecendo-o. Ao transitar entre dois mundos culturais diferentes, o americano e o sírio, a mídia estabelece dois lugares: o do eu e o do outro. Conflitos emergem desse contraste, ora em uma relação de subjugação do outro, colocando-o em posição de inferioridade, ora em uma espécie de ameaça à imagem americana.

Concluímos que, ao observar a guerra por uma perspectiva americana, o jornal The New York Times, por refletir um projeto hegemônico em plena expansão, transforma-se, em certa medida, em um agente dessa ação. Acreditamos que reconhecer as estruturas discursivas constituintes desse discurso é posicionar-se criticamente com relação ao que é produzido pela mídia.

Palavras-chave: Guerra na Síria, Discurso, Mídia, The New York Times, Soberania. 


\begin{abstract}
DEMICHELLI, Maurício. The Syrian War and the construction of American sovereignty: a discursive analysis of The New York Times coverage. 2018. Tese (Doutorado em Letras) - Faculdade de Filosofia Letras e Ciências Humanas, Universidade de São Paulo, São Paulo, 2018.
\end{abstract}

This thesis aims at studying the American discourse in the beginning of the Syrian war as seen by the perspective of The New York Times coverage. In a discursive approach, based mainly on Foucault's theories (1971), we focus on analyzing how the newspaper's narrative of the war, which comprises American cultural values, builds itself as a kind of episteme that shapes the understanding of the world, men, and reality.

We first propose a way of looking into our analytical corpus that allows for an observation of how the subject that is given the right to speak constitutes himself and his objects, namely the war and the enemy. Secondly, in accordance with theories developed by Hardt and Negri (2001) as well as Said $(1993,1999)$, we intend to observe how the discourse about the Syrian war is constructed based on an ideological and expansionist American project, which has been shaped since the onset of colonization and it is far beyond the nation's geographical borders. Lastly, we concentrate the analysis on the media as a producer of symbolic material which, in an attempt to give intelligibility to the war, tunes in with ideals that strengthen the American spirit. As the newspaper goes back and forth into the two different cultural worlds of America and Syria, the media establishes two distinct locations: one of the $I$ and one of the other. Conflicts, as a consequence, emerge from this contrast, sometimes in a relation of subjugation of the other by depicting it as inferior, other times as a threat to the American image.

We conclude that, by observing the war through an American perspective, the New York Times not only reflects a hegemonic project in full expansion but also functions to a certain extent as an agent of this process. We believe that to recognize the discursive structures present in this discourse is to engage critically in the observation and interpretation of what is produced by the media.

Keyword: Syrian war, Discourse, Media, The New York Times, Sovereignty 


\section{SUMÁRIO}

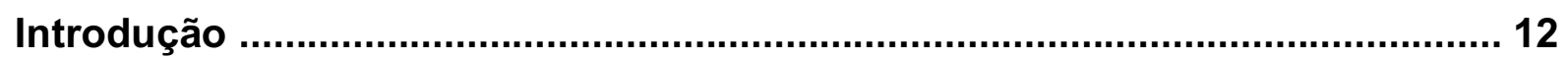

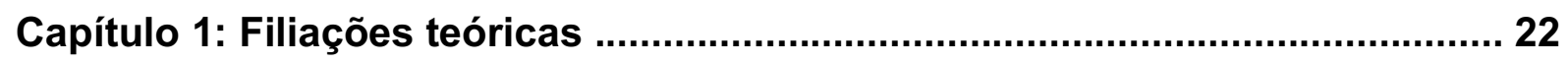

1.1. Uma concepção discursiva da linguagem ..................................... 22

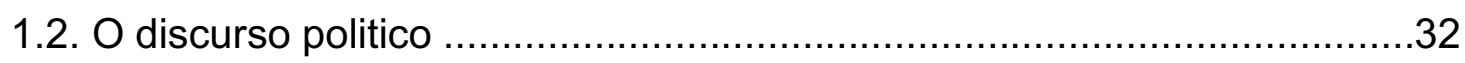

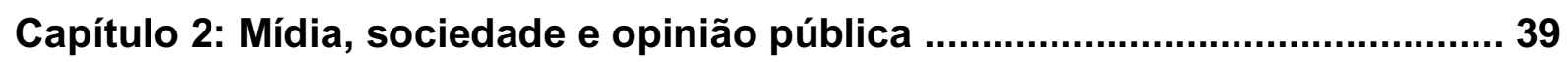

2.1. A estrutura jornalística: valor, produção e seleção ............................ 39

2.2. A recepção jornalística: público leitor, circulação e sociedade .............. 43

2.3. A tessitura jornalística: opinião pública e influências ......................... 47

Capítulo 3: A guerra na Síria: perspectivas críticas, sociais e históricas ........ 52

3.1. Relações Ocidente e Oriente: uma perspectiva externa ...................... 52

3.2. A Primavera Árabe: uma perspectiva interna .................................. 61

3.3. A Primavera Árabe: o caso da Síria, uma primavera de mais de quatro estações 68

Capítulo 4: Do funcionamento discursivo na cobertura da guerra na Síria pelo jornal The New York Times ....................................................................... 75

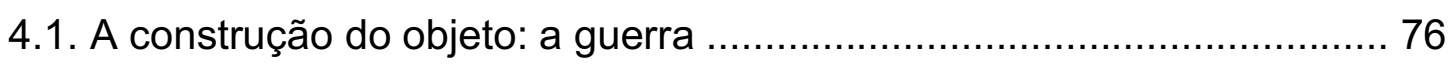

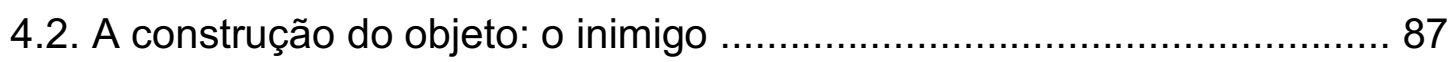

4.3. A construção do sujeito discursivo ............................................... 92

4.4. As polêmicas e contradições do discurso político ............................. 100

Capítulo 5: Das questões sobre o Oriente e o Ocidente ................................... 109

5.1. O papel da ONU e sua organização ideológica ................................ 110

5.2. A expansão americana e a conflituosa relação com o Oriente ............ 122

5.3. Oriente, o domínio do mal: os Rogue States e a fabricação

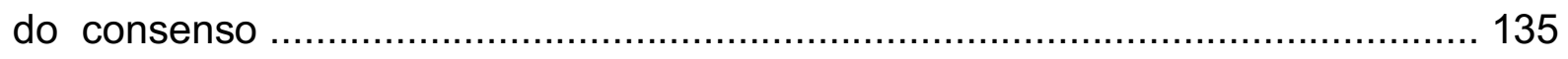

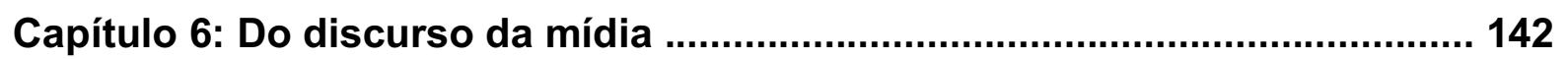

6.1. A inteligibilidade da guerra e os valores nacionais americanos ...........142

6.2. A construção discursiva da imagem: seu poder simbólico e cultural ... 148

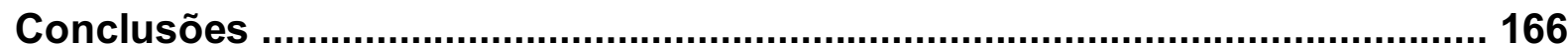

Referências Bibliográficas .................................................................... 172 
A privação fundamental dos direitos humanos manifesta-se, primeiro e acima de tudo, na privação de um lugar no mundo que torne a opinião significativa e a ação eficaz.

ARENDT, H. (2013, p. 424) 


\title{
Introdução
}

\begin{abstract}
our manifest destiny to overspread the continent allotted by Providence for the free development of our yearly multiplying millions ${ }^{1}$ (O'SULLIVAN, 1845, p.2)
\end{abstract}

A linguagem é, desde o princípio, o fenômeno que possibilitou ao homem a organização do mundo e a alteração das condições naturais. Foi por meio dela que o homem conseguiu abstrair a realidade e representar sua experiência e a si mesmo, tornando possível a classificação do mundo e a geração de sistemas e conjuntos que delimitam o que é visto, dito e ouvido em suas diferentes manifestações.

Aquilo que é produzido pelo homem é ancorado pela na sua produção linguística, podendo, consequentemente, ser estudado por meio dela. A escola, a religião, a arte e a cultura são exemplos de atividades organizadas e significadas a partir de um conjunto de textos que constroem, delimitam e materializam saberes e verdades.

Assim, a linguagem funciona como um laço social, podendo ser entendida como uma instituição social que não somente produz significações, mas também define os homens como produtores e, simultaneamente, produtos dessas significações.

Foi a partir do estabelecimento de laços sociais que os homens procuraram uma organização que objetivasse o bem comum, algo que pudesse, pelo menos em um nível teórico-idealista, acolher as diferenças e as pluralidades existentes no convívio entre pessoas. Trata-se de um conjunto de normas e regras chamadas de política que viabilizam a convivência e o desenvolvimento social e humano.

Alguns tomaram para si a criação e a gestão desse projeto, como sendo representativas do coletivo. Exatamente por tratar-se de um projeto que envolve todos os membros da coletividade, é necessária a criação de um espaço de discussão e elaboração desse projeto dentro da sociedade. Esse local é, caracteristicamente, constituído pela linguagem e pode ser variado.

\footnotetext{
${ }^{1}$ https://pdcrodas.webs.ull.es/anglo/OSullivanAnnexation.pdf
} 
Charaudeau (2005) afirma que a organização da vida em sociedade é uma atividade política de regulamentação social. Assim, desenvolvem-se três domínios de ação social: regular, legislar e distribuir. A partir desses domínios, surgem quatro estruturas ou lugares de organização: o jurídico, o econômico, o midiático e o político. Para o autor (2005), o centro organizador é o setor político; os outros sistemas estariam orbitando ao seu redor.

Como dissemos anteriormente, o laço social que une os indivíduos cria sociedades politicamente organizadas. De forma geral, essas comunidades buscam projetos que garantiriam, entre outras coisas, a convivência, o desenvolvimento e o progresso. Quando valores são apropriados por uma entidade, há coletivamente a criação de uma instituição abstrata, como o Estado, a Nação, a República, desapropriando os indivíduos e tornando-se um terceiro elemento.

Numa visão platônica, a instância política é, como dissemos, a representação dos indivíduos na elaboração e na gestão desse projeto comum, desempenhando, por essa razão, um papel legitimado de autoridade numa sociedade democrática. Os interesses em comum de uma nação devem se sobrepor aos individuais, e o papel da instância política é, então, garantir e proteger o interesse coletivo constituído por um projeto nacional. Sendo assim, a instância política transforma-se em Estado e ganha a qualidade de soberana.

A soberania se exerce em dois âmbitos: o interno e o externo. No interno, ela atua na elaboração de leis, planos e ações que pautarão a vida dos cidadãos. No âmbito externo, ela garante a participação da nação num teórico cenário de igualdade de Estados e colabora para o desenvolvimento de um plano norteador dos princípios fundamentais do comportamento humano. Arendt (1993) a concebe a política nos tempos modernos como um mal necessário para a liberdade social.

A obrigação de um governo é, dessa forma, proteger a nação interna e externamente, mesmo que à força, para cujo uso é necessário, ainda segundo Arendt (1993), controle e aprovação da instância cidadã, que protege e fiscaliza a ação do Estado. Nos tempos modernos, o espaço público se tornou um lugar de força, daí que um governo, hoje chamado de constitucional, deveria ser controlado pelos governados, fazendo com que a força se exerça de maneira bilateral.

Retornando ao conceito de soberania no âmbito externo, ao falar de um cenário internacional, de negociações ou de acordos externos, uma das principais práticas envolvidas em todo esse processo é a da política externa e da diplomacia. 
Essa prática pode ser compreendida, conforme a Convenção de Viena de 1961, como uma atividade cujo objetivo é a manutenção da paz e da segurança internacional por meio de promover o desenvolvimento e a amizade entre as nações. Assim a política externa pode entendida como um projeto local para uma participação global, e uma ameaça a essa prática significaria o rompimento de um projeto de princípios fundamentais do comportamento humano. Quando uma Nação vê sua soberania ou seu projeto comum ameaçado, há a justificativa para a defesa, mesmo que pelo uso da força. A guerra torna-se, portanto, o campo da política e da força.

Para Charaudeau (2005), não há política sem discurso. Ou seja, a linguagem é o que permite a existência de espaços de discussão, persuasão e sedução, por isso se diz que o discurso é constitutivo da política.

Foi pensando na política como esse centro organizador que julgamos pertinente uma pesquisa que pudesse analisar a articulação política em um espaço constituído basicamente de linguagem: a mídia. Ao utilizar a rede política como fonte de informação, a mídia passa a ser um elemento chave na compreensão do discurso político e de seus caminhos.

Escolhemos abordar o discurso político nesse cenário internacional, especificamente o da guerra, por entendermos que ações e transformações ocorridas nesse espaço refratam e refletem significados de abrangência global.

Em todos os grandes conflitos internacionais modernos, desde a primeira guerra mundial, passando pelas recentes guerras no Afeganistão e no Iraque, até os atuais conflitos na Síria e na Criméia, os Estados Unidos aparecem sempre no centro de todas as questões, principalmente quando veiculadas pelas mídias.

Dentro desse contexto, o País assume o papel de líder nas estratégias, nas negociações e no poder bélico. Esse papel pode ser compreendido tanto como o resultado de um projeto nacional já dos tempos da colonização com o enraizamento de valores nacionais baseados em um destino manifesto e uma predestinação, quanto como o poderio econômico de uma das nações mais ricas do mundo. Não há questão internacional que não clame um posicionamento americano, seja por vontade própria seja por exigência internacional.

Dessa maneira, o País se mostra ideal para um estudo sobre o discurso político nesse contexto internacional. O discurso político americano é, de certa forma, catalizador e emblemático de uma estrutura organizacional do mundo capitalista e globalizado que constrói valores mundiais de democracia e liberdade. 
A política externa de uma Nação pode ser vista como um diálogo constante entre seus líderes e a opinião pública, influenciado pelo debate midiático. Os textos produzidos pela mídia que abordam questões internacionais tornam-se práticas políticas que, por meio de práticas discursivas, produzem sentidos sobre a política, a economia, a cultura e as sociedades nacional e internacional.

Como nosso objetivo é o estudo do espaço da linguagem no domínio do discurso político articulado pela mídia, viabilizamos a pesquisa selecionando a mídia escrita estadunidense, mais especificamente o jornal e seus desdobramentos no mundo virtual, para objeto de nossas reflexões.

O debate político sempre se intensifica quando há um conflito. A guerra e todo discurso sobre ela parecem ser o cenário perfeito para o exercício da ação política e da luta pela soberania. Optamos, então, pela recente e atual guerra na Síria, que tem movimentado um grande cenário de debates, gerando uma grande quantidade de textos, discursos e sentidos.

Para analisar o discurso político na mídia, escolhemos o jornal The New York Times por se tratar não só de um jornal de grande circulação dentro e fora dos Estados Unidos, mas também por ser considerado, no meio jornalístico, uma referência do jornalismo mundial.

Segundo Davis (1921), um dos editores do jornal a partir de 1914, o The New York Times foi o resultado de uma série de acidentes que uniram seus dois sócios, Henry J. Raymond e George Jones. Os dois passaram por vários jornais antes de estabelecer o The Times. Conforme explica ainda esse mesmo autor, Nova York, que ainda não era uma grande metrópole, estava atraindo cada vez mais jovens em busca de um futuro, por isso carecia de um jornal sensível e sensato. Os jornais existentes eram, proposital e ironicamente, chamados de "blanket sheets", pois eram longos, grandes, caros e estúpidos, o que possibilitava a muitos "dormirem" sobre eles como em um cobertor.

Uma nova era no jornalismo começa, segundo o jornalista (1921), em 1833 no Reino Unido, com o estabelecimento do jornal The Sun, voltado para uma classe trabalhadora e não para uma elite que esbanjava tempo para ler outros jornais. 0 jornal, ainda que repleto de frivolidades, marca um novo campo de atuação. Dois anos mais tarde, aproveitando o mesmo espaço, surge o jornal Herald, de James Gordon Bennett, que, de acordo com Davis (1921) criou o que há de melhor, e pior, no jornalismo moderno. O fundador do Herald foi o primeiro a coletar notícias e a 
fundar o jornalismo amarelo, centrado em crimes e erros humanos. Considerado obsceno por muitos, o Herald colocava em risco valores morais da família americana.

Ambos, The Sun e The Herald, mostravam simpatia pelo partido democrático enquanto que o The Tribune inclinava-se aos Whigs. Considerado por Davis (1921) um combatente desse último jornal, Henry J. Raymond afirmava que esse jornal destruía o direito à propriedade, afetava a família e contrapunha-se contrário aos ensinamentos religiosos. Apesar de todos os esforços contrários, o The Tribune prosperou devido a muitas pessoas quererem as notícias sem o sensacionalismo do The Herald.

Ainda de acordo com o editor (1921), foi para esse público que Raymond e Jones decidiram apelar nos Estados Unidos. Não somente porque existia um público para esse "gosto", mas também porque a crença no partido democrático americano e em valores como propriedade, família e religiosidade eram crenças pessoais de Raymond.

A associação que publicaria o jornal The New York foi fundada sob o nome de Raymond, Jones \& Company em 5 de agosto de 1851; treze dias depois, publicouse a primeira edição. Em agosto de 1860, a associação mudou-se para $H$. J. Raymond \& Company e, em julho de 1871, para The New York Times. O jornal declarava como objetivo tornar-se o melhor e mais barato jornal diário familiar dos Estados Unidos.

Logo no primeiro editorial, escrito por Raymond, alguns objetivos e algumas propostas do jornal são claramente expressos, destacando-se a promessa de não escrever de forma passional, exceto apenas se esse fosse realmente o caso. Raymond complementou que havia poucas coisas no mundo dignas de raiva e que elas não melhorariam, se tratadas de maneira passional. Segundo Davis (1921), havia na mídia jornalística mais raiva do que o necessário, especialmente em controvérsias editoriais.

Conforme as informações publicadas em seu site $^{2}$, o objetivo do The New York Times é promover o desenvolvimento da sociedade por meio de criar, coletar e distribuir notícias e informações de alta qualidade. Três palavras definem os princípios do jornal: justiça, integridade e verdade.

No princípio de justiça, o jornal declara ser o mais imparcial possível, sem medo ou favorecimento. No da integridade, o jornal afirma ser uma das primeiras

\footnotetext{
${ }^{2}$ https://www.nytco.com/who-we-are/culture/our-history/
} 
obrigações de seus colaboradores zelar pela reputação do veículo. Apesar dessa afirmação, o jornal se coloca em caminho oposto ao assumir que, frente às recentes suspeitas de imparcialidade, acuidade e integridade, seus jornalistas estão garantindo os mais altos padrões com o fito de não abalar a confiança de seus leitores. No terceiro princípio, a verdade, o jornal se coloca em posição de reportar as experiências da maneira mais fiel possível, isto é, de acordo com o que é perceptível e possível, corrigindo as informações sempre que necessário e tratando o plágio e a informação falsa deliberadamente emitida com muito rigor, por não tolerar tais comportamentos.

Dentro de sua web site, entre outros documentos, o jornal mantém disponível a seu público dois guias: um sobre integridade e outro sobre ética. Além de uma versão nacional, o jornal conta com uma edição internacional em Língua inglesa que circula em diferentes países e possui matérias traduzidas que incorporam seções de portais e jornais nacionais de todo o mundo com a marca The New York Times. No Brasil, por exemplo, o jornal Folha de S.Paulo possui uma seção na qual traduz artigos produzidos pelo jornal americano.

Utilizando o The New York Times como fonte de nosso corpus, buscamos montar um panorama da guerra da Síria, retratada pelas edições publicadas de março de 2011 até o início de 2013. Cobrimos com essa delimitação, o momento inicial dos conflitos na Síria, anteriores ao envolvimento do grupo Estado Islâmico. Optamos por esse período, pois ele delimita o princípio da construção discursiva relativa à guerra da Síria, quando os valores e os saberes sobre a guerra ainda estão em formação. Com isso, analisamos o modo como o jornal The New York principiou a narrativa da guerra e a maneira como o discurso foi articulado.

O levantamento de artigos e reportagens aqui analisados foi feito no banco de dados do jornal disponível na internet. ${ }^{3} \mathrm{O}$ jornal mantém um acervo online completo de suas edições desde 1885 e apresenta os resultados de pesquisa em formato de links para reportagens, artigos de opinião e material digital de domínio da instituição. Usamos como critério de busca expressões simples, como: Syria, syrian war e syrian civil war filtradas por data, dentro do período de recorte determinado para a constituição do corpus da pesquisa. Feito isso, obtivemos um número bastante razoável de artigos e reportagens que foram analisados de acordo com os objetivos da pesquisa.

\footnotetext{
${ }^{3}$ http://www.nytimes.com/search/sitesearch/
} 
Justifica-se a escolha do tema, da perspectiva teórica e do objeto de estudo pela forte influência da mídia americana no mundo contemporâneo, como fonte primária ou secundária de informações. Acreditamos que a mídia estadunidense carrega valores que refletem um projeto ideológico americano de caráter expansionista, o qual molda a forma com que percebemos a experiência mundial, mesmo que não façamos parte de sua cultura local. Muitas vezes, esse molde se torna a única fonte na percepção do mundo, da realidade e do outro.

Cremos que nossa percepção de mundo, e em especial nossa maneira ver outra cultura, deve ser tratada de forma crítica se desejamos realmente compreender o outro em toda a sua diversidade de pensamento, crenças e ações. Talvez, dessa forma, consigamos ser mais respeitosos com o diferente para, então, compreendê-lo na sua forma de pensar, crer e expressar-se.

A perspectiva discursiva utilizada nas análises permite que essa crítica se construa, tornando-nos mais críticos em nossa relação com a linguagem. Analisar a linguagem em sua materialidade discursiva, em seu diálogo com outros discursos historicamente constituídos e em sua capacidade de transformar uma estrutura em um acontecimento é de grande valia na formação de um leitor crítico. A nosso ver, o jornal, como instituição cultural, é uma fonte discursiva por meio da qual podemos observar a existência de uma série de outros discursos consonantes ou antagônicos que buscam o seu lugar. Nesse sentido, Foucault afirma que:

"em toda a sociedade a produção do discurso é ao mesmo tempo, controlada, selecionada, organizada e redistribuída por certo número de procedimentos que têm por função conjurar seus poderes e perigos, dominar seu acontecimento aleatório, esquivar sua pesada e temível materialidade" (FOUCAULT, 1971, p.8)

Ao retratar a guerra em uma cultura completamente diferente da sua, o jornal passa a definir o outro conforme sua própria constituição cultural, tornando o que é diferente de si em uma projeção de sua própria verdade por meio de obedecer aos valores culturais do eu-enunciador.

Partimos, então, da tese de que a cobertura jornalística americana dos grandes jornais, como o The New York Times, reflete o discurso de um projeto hegemônico dos Estados Unidos que busca sua expansão. Esse projeto está na base de formação do País desde seu início, sendo, portanto, parte de uma episteme de compreensão do mundo, dos homens e da realidade. 
Para a discussão de nossa tese, propomos as seguintes questões:

1. Como o discurso da mídia constrói, além do saber sobre a guerra da Síria, os participantes nela envolvidos?;

2. Como o projeto nacional americano constrói sua expansão por meio da mídia?;

3. Qual o papel das organizações internacionais, como a ONU, na constituição de uma ideologia que perpassa as fronteiras dos países em conflito e reflete um projeto hegemônico ocidental?;

4. Como, na narrativa da guerra da Síria, a mídia e mais especificamente o jornal The New York Times atribui, constrói e reforça valores que refletem a forma como o País vê o mundo a partir de sua própria cultura e de seus próprios valores?

Para responder a essas perguntas, propomo-nos os seguintes objetivos:

1. Analisar o discurso da mídia relativo aos sujeitos envolvidos na guerra da Síria; 2. Refletir sobre tanto os conflitos inerentes ao discurso político, quanto suas posições antagônicas e, ainda, suas contradições internas;

3. Entender a forma como se constrói o discurso baseado em uma ideologia nacional e em outros discursos em que ele se ancora;

4. Compreender o papel da mídia na construção discursiva de um discurso hegemônico americano.

Buscando responder às essas perguntas de pesquisa, dividimos este trabalho em seis capítulos, três de natureza teórica e três de cunho analítico.

Para a constituição do percurso teórico, desenhamos no capítulo 1 uma concepção discursiva da linguagem, apoiada no conceito de discurso, tal como entendido por Foucault (1971). Ainda do mesmo autor, exploramos a noção de construção de saberes e verdades que legitimam formas de poder. De Foucault (1966) e dos trabalhos de Dreyfus e Rabinov (1995), resgatamos o entendimento da episteme como forma de compreensão da experiência e do mundo. O trabalho de Orlandi (2000) colabora também para a visão discursiva elaborada no capítulo, em também abordamos a questão da ideologia, conforme a discussão de Bakhtin (1929) e 
Althusser (1971). Finalizando o capítulo, observamos o funcionamento do discurso político, tendo como base os trabalhos de Courtine (2006) e Charaudeau (2005).

No capítulo 2, apresentamos o funcionamento da mídia, colocando em perspectiva teórica as questões de produção e recepção das notícias e o relacionamento da mídia com a sociedade. Para isso, observamos os trabalhos de Golding e Eliot (2009) no que diz respeito à estrutura e funcionamento da mídia, particularmente a relação de conceitos, como valor, seleção, objetividade e ideologia. De Hall (2009), estudamos a questão das fontes que a mídia usa em seus trabalhos com a finalidade de estabelecer uma grande agenda de interesses. Tarde (1992) auxiliou na compreensão da relação entre a mídia e o publico leitor; e Thompson (2009), da relação entre a mídia e a sociedade. Por último, de Wittkopf (1996) e Baum e Potter (2008), buscamos a relação entre as ações políticas e a opinião pública, sendo a mídia a mediadora dos atores envolvidos.

O capítulo 3 é dedicado ao estudo das perspectivas históricas e sociais do Oriente Médio, com especial ênfase ao caso da Síria e à relação entre o Ocidente e o Oriente. Utilizamos as perspectivas teóricas sobre Orientalismo, de Said (1978, 1999), e os conceitos de Império de Hardt e Negri (2001), além das ideias de Chomsky (1999 e 2005) sobre os Rogue States e o Império do mal.

Apresentamos, também, um panorama histórico da chamada Primavera Árabe, desde seu primeiro conflito na Líbia, passando pelos países que entraram em recentes conflitos com seus governos, até chegar no caso da Síria, objeto desta pesquisa.

No âmbito analítico, respondemos no capítulo 4 a nossa primeira pergunta de pesquisa, analisando a estrutura discursiva e a construção da guerra, do sujeito e do objeto. Também observamos as regularidades discursivas do jornal The New York Times que constituem a guerra e seus atores a fim de compreender o funcionamento do discurso político americano.

O capítulo 5 é dedicado à análise das relações entre o ocidente e o oriente. Partindo das teorias propostas no capítulo 2, analisamos a construção discursiva da noção de Império, principalmente no que tange ao papel da ONU e a sua base ideológica. Também consideramos como o discurso da mídia engendra a noção de soberania da própria ONU e dos países que a compõem, em especial dos Estados Unidos. Finalmente, no mesmo capítulo, verificamos como os textos produzidos pelo 
jornal constroem a imagem do Império do mal, ou Rogue States, conforme proposto por Chomsky (1999).

No último capitulo, destacamos o papel da mídia na construção de valores e imagens de um poder simbólico intimamente ligados a uma ideologia americana. Ainda nesse capítulo, abordamos de que maneira essas imagens funcionam como uma episteme de compreensão do mundo a qual permite a guerra ser vista de uma forma particular.

Por fim, apresentamos nossas considerações finais e as referências bibliográficas. 


\title{
CAPÍTULO 1 - FILIAÇÕES TEÓRICAS
}

\author{
Mas, o que há, enfim, de tão perigoso no fato de as pessoas falarem \\ e de seus discursos proliferarem indefinidamente? Onde, afinal, está o \\ perigo? \\ (FOUCAULT, 1971/2004, p.8)
}

O presente trabalho situa-se epistemologicamente nos territórios do discurso o que justifica, necessariamente, uma aproximação com concepções e teorias fundamentais do discurso. Inicialmente esboçamos a concepção discursiva baseada, em especial, nos pensamentos de Michel Foucault (1971) e nos apropriamos de dois outros conceitos por ele desenhados, ambos relevantes para nossa pesquisa: o de enunciado e o de episteme. A seguir, elencamos os principais preceitos da Análise do Discurso de linha francesa, a partir de cuja perspectiva nos alinhamos, especificamente, ao discurso político.

\subsection{Uma concepção discursiva da linguagem}

Tomando como ponto de partida a ideia de que o objeto é delimitado, percebido e representado a partir de um conjunto de discursos que o constitui como objeto, Foucault, em As Palavras e as Coisas (1966), afirma que práticas discursivas dão origem a uma episteme, entendida como um conjunto de relações que se estabelecem em um dado momento histórico para constituir uma verdade, um saber que circula na sociedade.

Assim, o autor (1971) afirma que não há como tomar a palavra sem estar envolvido por um discurso, por um passado de ditos e re-ditos, compreendendo o discurso na ordem das coisas, ou seja, na ordem das leis. Por ser uma produção discursiva selecionada, organizada e controlada, estamos constantemente redistribuindo discursos para que poderes, de acordo com a concepção foucaultiana, possam permanecer ou transformar-se em outros. 
O discurso vincula-se não apenas com aquilo que dizemos e reproduzimos, mas também com aquilo que não dizemos. Com frequência somos discursivamente interditados a não falarmos tudo e em todos os lugares. Essa interdição, além de impedir a realização do discurso, separa-o, classifica-o e exclui-o. Assim como o louco, que é definido pelo seu discurso e, consequentemente, excluído por ele, os falares são objetos de segregação institucional. O louco é interpretado por um saber construído no âmbito teórico institucional da ciência médica e, consequentemente, julgado por ela.

Dessa forma, podemos dizer que todos os discursos se submetem a saberes institucionais que julgam, excluem, separam e interditam. As instituições constituídas e legitimadas nos âmbitos social, político e econômico, segundo o autor (1971), proferem o chamado discurso da verdade, que leva em conta o pronunciamento da palavra por aquele que tem o direito a ela, conforme a circunstância e o ritual. Logo, podemos entender o discurso como uma espécie de sujeição ou rejeição ao discurso institucionalizado. Mas, segundo Foucault (1971), o discurso não é apenas o cenário das lutas e dominações, mas o objeto de poder que desejamos. Esse processo está no âmbito externo ao discurso e age como forma de controle e delimitação de verdades. Internamente, entretanto, os discursos exercem seu próprio controle por meio de mecanismos de classificação, ordenação e distribuição. São princípios internos que instauram uma dimensão discursiva baseada no acontecimento e no acaso.

Ainda para o autor (1971), em todas as sociedades, existem narrativas que se contam e recontam discursos ritualizados os quais, ditos uma vez, se conservam por residir neles um segredo, ou uma espécie de riqueza. São discursos que fundamentam novos atos discursivos e que, estando para além da própria forma, da própria formulação, como os textos religiosos, os jurídicos, os literários e os científicos, emergem como um comentário que faz reaparecer a o discurso comentado. Dessa forma, esse comentário constrói um novo discurso e paradoxalmente articula, em segundo plano, o que estava no texto primeiro. Isso significa "dizer pela primeira vez aquilo que, entretanto, já havia sido dito e repetir incansavelmente aquilo que, no entanto, não havia jamais sido dito". (FOUCAULT, 1971/2004, p.25).

Visto nessa perspectiva, o autor é apenas o principio organizador do discurso, isto é, a origem de sua significação, enquanto que o discurso parte da organização de outros discursos circulantes. Mesmo discursos novos devem, nas palavras de 
Foucault (1971/2004, p.35), obedecer às "regras de uma "polícia" discursiva que devemos reativar em cada um de nossos discursos.".

Outro mecanismo de controle do discurso diz respeito às condições de funcionamento. Certas regras, como que num ritual a ser satisfeito, não permitem que todos digam as mesmas coisas. O que está presente no discurso é aquilo que satisfaz certas exigências e se mostra qualificado para tanto. Por isso, a posição do sujeito discursivo, o individuo que fala, determina todo um comportamento que acompanha o discurso.

Grupos sociais, chamados alusivamente por Foucault de "sociedades de discurso", são responsáveis por produzir e manter discursos. São esses mesmos grupos que fazem com que a produção discursiva assuma um papel doutrinário já que ela é distribuída em um lugar fechado. Havendo a partilha de um só discurso, ou mesmo de um conjunto de discursos, todos do gruo social reconhecem a mesma verdade e a mesma doutrina, aceitando, então, suas regras de produção e circulação.

O reconhecimento dessa produção discursiva estabelece um tipo de enunciação que funciona como um mecanismo que liga indivíduos e, ao mesmo tempo, os separa de outros. Sem separar esses dois processos, Foucault (1971) chama esse conceito de sujeição do discurso: um ritual da palavra que fixa papeis e constitui grupos doutrinários.

Dessa forma, o ritual da palavra segue o princípio da alteridade. Segundo Charaudeau (2005), trata-se de um fenômeno de troca entre dois participantes, presentes ou não, os quais se reconhecem por compartilhar saberes e papéis e, simultaneamente, se legitimam tanto no reconhecimento quanto na diferenciação.

Assim, Foucault (1971) procura analisar o sujeito fundante, a experiência original, ou seja, aquele que parte da simples experiência, de um conhecimento ou de uma observação nova para constitui um saber. Foucault afirma que, mesmo se analisada a fundação do discurso ou a percepção da experiência, há, de certa forma, significações anteriormente já ditas. A relação com o mundo, chamada por Foucault de "cumplicidade", é o que permite ao indivíduo falar de si e do mundo. O objeto "murmura" uma compreensão, não intrínseca a ele, mas originária de discursos que norteiam sua percepção, estabelecendo um jogo dinâmico de leitura, escritura e troca. Analisar esse jogo em suas condições e significações seria, segundo o autor, "questionar nossa vontade de verdade, restituir ao discurso seu caráter de 
acontecimento; suspender, enfim, a soberania do significante." (FOUCAULT, 1970/2004, p.51).

Para analisar o discurso deve-se, conforme o autor (1971), considerar que os discursos são acontecimentos, isto é, acontecem em série, obedecendo a regularidades e aparecendo quando há condições.

Foucault (1971) compreende o acontecimento no âmbito da materialidade, como um efeito do ato e da propriedade do objeto em uma dispersão material. Tratase do materialismo do incorporal. Nesse sentido, o discurso passa a ser visto não mais como representações existentes por trás dos discursos, mas sim como séries regulares de acontecimentos que constituem o objeto.

O autor, do mesmo modo, buscando compreender o discurso, propõe uma análise baseada, em primeiro lugar, no principio crítico que busca as formas de exclusão, apropriação e limitação do discurso e, em seguida, na observação de um conjunto "genealógico" que explicite como esses discursos se formaram com base em sistemas de coerção.

Dreyfus e Rabinow (1995) afirmam que, para Foucault, o enunciado assume posição central nos estudos discursivos. O enunciado, para o autor, não é, em primeiro lugar, uma enunciação ou uma proposição, uma entidade psicológica ou lógica, nem é, em segundo lugar, é um acontecimento ou uma forma ideal. A identidade de um enunciado é, portanto, relativa, e se modifica de acordo com o uso que se faz dele e de acordo com a maneira pela qual ele é manipulado. O enunciado é um "ato discursivo" e deve ser colocado no contexto real de outros enunciados para obter significação.

Deleuze (1986) afirma que, para Foucault o enunciado é raro. Cada frase se amplia com tudo o que não diz, com conteúdo virtual ou latente que multiplica o seu sentido para então poder ser interpretado. Um enunciado possui um discurso oculto, por isso é inseparável de um espaço da realidade.

De acordo com Dreyfus e Rabinov (1995), Foucault interessa-se pelos atos discursivos que retomam dizeres de outros tempos e de outros lugares. Esses atos parecem ganhar autonomia após passarem por uma espécie de teste institucional e são chamados de verdades desde que obedeçam às regras de uma "polícia" discursiva. Afirma-se algo com base em um método anteriormente aceito. Os autores (1995) chamam aos atos das formulações de Foucault de "atos discursivos sérios", 
pois são verdades da realidade inseridas num contexto: elas não existem isoladamente.

O enunciado não precisa, necessariamente, de um sujeito enunciador, mas, segundo Deleuze (1986), precisa de um espaço de enunciação. Nessa perspectiva, o enunciado é em si uma origem, uma memória, que vive enquanto durar seu espaço, enquanto puder ser reconstruído.

Nessa perspectiva, qualquer ato pode ser sério, desde que preencha certos procedimentos de validação, como, pertencer a uma comunidade de especialistas. Foucault (1971) aponta que há em nossa sociedade uma vontade da verdade razão por que tentamos converter quaisquer atos discursivos do nosso cotidiano em atos discursivos sérios. Esses atos são constantemente justificados e refutados com a pretensão de transformá-los em um saber e, assim sendo, são usados, repetidos e transmitidos. São atos discursivos com aspirações de verdades.

Dreyfus e Rabinow (1995) afirmam que Foucault se interessa por esse tipo de "ato discursivo sério" na Arqueologia do Saber. As regularidades desses atos e suas relações com atos discursivos semelhantes ou opostos geram a formação discursiva, noção estabelecida por Foucault, para cujo estudo é necessário questionar as reivindicações de verdade dos atos discursivos sérios e seus significados.

Analisar um enunciado é passar por uma análise histórica, como já mencionamos anteriormente, que deve se colocar contra as interpretações, perguntando-se de que maneira elas existem e por que são elas que apareceram, e não outras.

Segundo Deleuze (1986), Foucault estabelece três espaços ao lado de um enunciado. O primeiro é o espaço colateral, formado por uma associação de outros enunciados integrantes de um mesmo grupo, de uma mesma formação discursiva. $O$ segundo é o espaço correlativo, estabelecido não pela relação com outros enunciados, mas pela relação com seu sujeito, objeto ou conceito. O primeiro espaço é o da língua, o da estrutura; o segundo, o da exterioridade. O terceiro é o espaço complementar, um local de formações não discursivas em que habitam as instituições, os acontecimentos econômicos e os políticos. Trata-se de um horizonte, no qual um enunciado pode aparecer, uma materialidade que o faz repetível.

Os atos discursivos sérios são os envolvidos em um sistema que obedece a regras. De acordo com Dreyfus e Rabinow (1995), Foucault observa que, no seu conjunto, há elementos relacionais nas regras; assim, a decomposição do conjunto 
em partes e o estabelecimento de suas relações sistemáticas tornariam a análise dos enunciados possível. Analisar enunciados não é analisar a estrutura e a relação entre seus elementos, segue Foucault, mas sim analisar o conjunto de regras que permitem sua existência e formulação.

Para estudar os enunciados sérios, afirmam Dreyfus e Rabinow (1995), temos de considerá-los em rede de práticas discursivas, abordando-os como conjunto de elementos inter-relacionados. É exatamente por esses atos discursivos sérios formarem um sistema ligado a indivíduos de uma determinada época e lugar que eles podem ser estudados a partir de seu exterior. Se esses enunciados só fazem sentido dentro de uma formação discursiva que os torna verdadeiros, então a análise das formações discursivas pode mostrar as condições do seu aparecimento.

Ao analisar as formações discursivas, Foucault estabelece quatro categorias descritivas, segundo Dreyfus e Rabinow (1995): os sujeitos, os objetos, os conceitos e as estratégias.

Quanto aos objetos, Foucault percebe que agrupar os atos discursivos que fazem referência a objetos poderia levar a crer que esses se encontram fora do discurso, e isso seria inviável, pois são as formações discursivas que produzem o objeto. Dreyfus e Rabinow (1995) afirmam que o objeto é constituído pelos enunciados que o circundam, sendo as práticas discursivas que sistematizam os objetos e suas relações com outros discursos e com sistemas não-discursivos aos quais elas servem.

Com relação aos sujeitos, Foucault indaga quem pode ser considerado seriamente e quais relações discursivas permitem que locutores enunciem seriamente e transformem enunciados em verdades. Um exemplo usado por Foucault é a palavra médica, que deve vir de um "personagem" com direito a enunciá-la. Um campo de práticas discursivas, em constante transformação tanto no tempo como no espaço, dá ao enunciador o direito de enunciar.

A ideia de o objeto ser delimitado, percebido e representado a partir de um conjunto de discursos constitutivo dele nos leva à compreensão de que qualquer percepção do mundo evocaria um conjunto de discursos capaz de fazer-nos perceber o mundo de uma forma, e não de outra. As palavras, que então constituem um dado objeto, advêm de um conjunto de outros discursos situados nas mais diversas formações discursivas.

Segundo Deleuze (1986), Foucault, em As Palavras e as Coisas, alega que os enunciados são anteriores às frases; eles são os "formadores de palavras e 
objetos" (DELEUZE, 1986/1988, p.24). O sujeito é uma primeira pessoa que começa no discurso.

Dessa forma, podemos entender que práticas discursivas dão origem a uma episteme, a um conjunto de relações que se estabelecem em um dado momento histórico para constituir uma verdade, um saber que circula na sociedade.

Dreyfus e Rabinow (1995) afirmam que, na arqueologia das ciências humanas desenvolvida por Foucault, o autor busca um estudo no qual se possa verificar como teorias são formadas a partir de um saber. As experiências, as ideias e as ciências se constituem a partir de um saber determinado historicamente e construído a priori. Partindo desse princípio, Foucault desenvolve a noção de episteme, que, segundo os autores (1995), teve curta duração, por causa de uma mudança na trajetória dos estudos feitos pelo autor, e não por sua formulação.

Por episteme, Foucault, consoante Dreyfus e Rabinov (1995), compreende um conjunto de relações que unem práticas discursivas em uma determinada época. Sendo assim, se analisarmos as regularidades discursivas, poderíamos perceber, dentro de uma época, um conjunto de relações entre as ciências que produzem saberes e verdades. Essas relações não constituiriam uma grande teoria, mas se caracterizariam como um espaço de dispersão no qual um jogo de discursos busca sua significação. Portanto, se entendermos que os saberes são constituídos em uma arena de luta de significações, poderemos perceber que a episteme, sendo puramente discursiva, é heterogênea assim como o discurso o é.

Os autores (1995) complementam que, para desenvolver o conceito de episteme, Foucault analisa especificamente a episteme clássica. Essa episteme busca explicar a ordem, independentemente do objeto, que consiste numa ordenação progressista de objetos, visando a certas verdades. Pode-se pensar que se trata de uma espécie de, segundo Dreyfus e Rabinow (1995), imagem da verdadeira ordem do mundo. Diga-se que, nessa linha de pensamento, já há uma ordem pré-existente no mundo, cabendo ao homem apenas a sua descrição. O homem descreve, entende e esclarece, mas não cria.

No final da Época Clássica ocorreu, segundo Foucault, uma mudança de paradigmas. Para Dreyfus e Rabinow (1995), Foucault observou uma mutação arqueológica que possibilitou o aparecimento do homem nas relações com as coisas naturais. Nessa mudança, a ordem do mundo não era mais dada por Deus: o homem, apenas um ser ao lado de outros, se tornou então um sujeito entre objetos. Dessa 
forma, o homem passou a compreender não somente os objetos do mundo, mas também sua própria existência, tornando-se sujeito e objeto de seu conhecimento. $E$, dentro dessa nova concepção, a representação de mundo só poderia ser possível a partir do próprio homem. Segundo os autores (1995), essa mudança de paradigma é uma tentativa de mostrar como as representações são possíveis, sendo o homem não apenas o sujeito e o objeto do conhecimento, mas ainda o organizador de seu mundo. O início da modernidade traz a ideia de um ser finito que, por não tomar o lugar de Deus, não compreende e não pode apreender toda a realidade. O saber é criado exatamente pelos limites do conhecimento do próprio homem.

A verdade passa a ser determinada por um esquema conceitual de práticas discursivas. A noção de verdadeiro e de falso não faz mais sentido, pois está ligada a discursos que legitimam seus saberes. Foucault aceita a ideia de que a experiência do objeto está na relação que ele mantém com outros objetos, o chamado "horizonte exterior", que opera no âmbito discursivo, quando a linguagem perde seu caráter e o reconhecimento da origem. A linguagem, segundo os autores (1995), por ser em si um tipo de saber constituído, não pode ser conhecida objetivamente.

Desta forma, o discurso pode ser visto como uma episteme da percepção da experiência e da representação de mundo, dos acontecimentos e do próprio homem.

Definidas as noções de discurso, formação discursiva, episteme e enunciado, bem como os conceitos de sujeito e objeto, a serem usadas em nossa pesquisa, passamos a discorrer sobre as contribuições da Análise do Discurso ${ }^{4}$ de linha francesa, complementando, dessa forma, o quadro teórico presente nesse trabalho.

Com base em Foucault e Pêcheux, Orlandi (1999) vê o discurso como aquilo que possibilita ao homem significar e significar-se. O discurso constitui o homem e, ao mesmo tempo, é constituído por ele, por essa razão a $A D$ objetiva não só a relação da linguagem com sua exterioridade, ou seja, como o homem se relaciona com a realidade e com o social, mas também o modo como o texto significa.

Visto por esse ângulo, o discurso é o lugar a partir do qual se pode observar a relação entre língua e ideologia, já que qualquer discurso é ideológico. O modo como nos relacionamos com o real é sempre uma representação, conforme Foucault, e toda

\footnotetext{
${ }^{4}$ Daqui para frente AD.
} 
representação é atravessada pela ideologia. E a linguagem não escapa dessa premissa, já que é um fenômeno de representação e, portanto, ideológico.

A AD vê a língua em sua relação sócio-histórica, associando língua, discurso e ideologia e, para isso, articulando três áreas do conhecimento: a Linguística, a Filosofia marxista e a Psicanálise. Da primeira ela, retira as noções de língua, discurso e o da não transparência da linguagem. Da segunda, o conceito de que o homem faz a história e que a língua é historicamente constituída. Também do marxismo vem a noção ideológica de linguagem. Segundo Bahktin (1929), tudo que é ideológico remete a algo que está fora de si, remete a um signo; sendo assim, o universo da ideologia é o mesmo do signo. A língua, por sua vez, é um dos signos mais presentes nas relações sociais e, sendo signo, é ideologicamente constituído.

A palavra é o fenômeno ideológico por excelência (...) é o modo mais puro e sensível de relação social (...) É, precisamente, na palavra que se revelam as formas básicas, as formas ideológicas da comunicação semiótica" (BAKHTIN, 1929/1999, p.36).

A palavra, para Bakhtin, é o material sensível da ideologia e das transformações sociais, sendo, portanto, nela que se acumulam todos os aspectos ideológicos do corpo social, por isso é o objeto mais concreto para observar a ideologia, cuja noção é um dos pressupostos básicos da AD. Conforme Brandão (1998), o conceito de ideologia, em uma perspectiva marxista, está sempre associado às condições sociais em que as ideias se produzem; em outras palavras, as condições materiais em que o homem vive determinam a ideologia. Para Marx, ideologia, ou força espiritual, é a da classe dominante, isto é, o instrumento de dominação daqueles que detêm os meios de produção. Por meio desse instrumento, a classe dominante pode prescrever como a sociedade deve pensar, agir, fazer etc. É com a ideologia que se criam os valores e o modo de conduta de toda a sociedade. Assim, e no entender de Marx, a ideologia é simplesmente um instrumento de dominação, que tem como função iludir e dissimular a realidade.

Também Althusser (1971) afirma que a classe dominante cria mecanismos mantenedores e reprodutivos da ideologia, sendo papel do Estado criar aquilo que ele chama de Aparelhos Repressores e Aparelhos Ideológicos, (ARE e AIE, respectivamente). Do primeiro, podemos citar, como exemplo, as prisões e tribunais, ou seja, a lei; do segundo, as instituições como a escola e a Igreja, que seriam os 
verdadeiros controladores da ideologia. O autor vai um pouco mais adiante ao estabelecer algumas regularidades para o funcionamento da ideologia, por meio da qual, segundo ele, nos relacionamos com o mundo real.

Toda visão da realidade é impregnada pela ideologia, por isso a maneira como vemos o mundo é ideologicamente constituída. A ideologia, segundo ainda Althusser, tem existência material, já que se materializa pelas práticas dos aparelhos ideológicos. Para o autor, é a ideologia que interpela os indivíduos em sujeitos. Todo indivíduo concreto, quando inserido em determinado contexto social e histórico, é constituído ideologicamente razão por que passa a ser sujeito. Inserido em diversos aparelhos ideológicos, o indivíduo assujeita-se.

Sugerimos então que a ideologia 'age' ou 'funciona' de tal forma que ela 'recruta' sujeitos dentre os indivíduos (ela os recruta a todos), ou 'transforma' os indivíduos em sujeitos (ela os transforma a todos) através desta operação muito precisa que chamamos interpelação. (ALTHUSSER, 1971/2001, p.96)

A noção de assujeitamento é vista pela Psicanálise da qual a AD retira a noção de sujeito, constituído na história e em sua relação com o simbólico. O papel do sujeito complementa a relação discurso-ideologia, já que ele é concebido sob uma teoria materialista: é constituído historicamente, é interpelado pela ideologia e é atravessado pelo discurso e pelo inconsciente.

A noção de discurso, embora baseada em Foucault (1971), ganha posteriormente uma visão materialista em Pêcheux (1975 e 1983). O discurso é visto pela $\mathrm{AD}$ como a articulação entre o linguístico e o extralinguístico, como a intersecção entre aquilo que é dito pela língua e as condições de enunciação desse dizer.

Exatamente por estar na articulação do linguístico com o extralinguístico, Courtine (2006) afirma que a AD vê o texto como "um objeto político". E isso, porque a análise histórica das condições de produção do discurso é necessariamente política e econômica; busca-se um objeto que existe na tensão entre história e língua. Logo de início, nos anos 70, o discurso político se tornou o principal objeto de estudos da $A D$, quando se procurava identificar suas condições de aparecimento e produção, seus princípios, suas regularidades, suas imposições e suas apropriações.

Courtine (2006) aponta que todo discurso concreto é constituído por um conjunto de outros discursos, chamados de interdiscurso. Nesse caso, o sujeito fala 
no interior de uma formação discursiva, e sua fala, totalmente dependente do interdiscurso, é dada pelo pré-construído. Dessa maneira, o discurso sempre é anterior e independente do sujeito do enunciado.

Maingueneau (1997) aponta como característica essencial do discurso a ideia de que ele se situa para além da frase, sendo, então, orientado, contextualizado e assumido por um sujeito e regido por normas. Daí, todo discurso ter de ser considerado no interdiscurso.

A memória é a chave principal para o entendimento do interdiscurso, que se sustenta no já dito em outro (s) lugar (es). É o já-dito que se mostra no que está sendo produzido aqui e agora, a partir de nossa memória discursiva, articulando sentidos jáditos dentro da formação discursiva que nos é apresentada.

Vistas as contribuições da $A D$ de linha francesa para o quadro teórico que delimitamos e estabelecidas as ligações entre a língua e sua exterioridade e as condições de produção ideologicamente constituídas, estendemos o escopo teórico da pesquisa, discorrendo sobre o discurso político, que, em grande medida, é parte constituinte do objeto de estudos.

\section{2 - O discurso político}

A $A D$ reconhece que o trabalho com o discurso político apresenta contradições ideológicas típicas desse corpus. Segundo Courtine (2006), o discurso político é interativo, polêmico e conflituoso, devendo ser pensado sempre em termos de suas contradições ideológicas e de seus enfrentamentos. Contraditório, não se apresenta a partir de uma escolha do sujeito, mas sim a partir de um conjunto de posições de sujeito ou de modos diferentes de enunciação.

Circulando em um espaço público entre diferentes atores que buscam persuadir seus interlocutores por necessidade ou por desejo, o discurso de persuasão da opinião pública busca a legitimidade para as ações políticas, garantindo mudanças jurídicas que estabelecem a ideia de soberania.

Segundo Charaudeau (2005), o discurso político, resultado de uma estratégia do enunciador, é um jogo de máscaras no qual cada palavra diz e não diz. Esse sujeito 
enunciador político possui meios e estratégias discursivas para persuadir e seduzir seus interlocutores.

A palavra política precisa ser entendida antes de se entender o discurso político, afirma o autor. A palavra, na medida em que circula no espaço público, possui uma ampla conexão com relações de poder que trafegam por esse espaço. Segundo Courtine (2006), o discurso político é um lugar de memória, que, na política, é um poder que garante uma ideia de patrimônio verbal.

A questão central da política está na ação que um sujeito exerce no outro. Charaudeau (2005) cita três princípios que governam essa troca de ações entre sujeitos: o princípio da alteridade, segundo o qual um se define pelo outro; o princípio da influência, de acordo com o qual se espera que o outro aja em função dos interesses do um; e o princípio da regulação, conforme o qual o um também tem um projeto de influência sobre o outro, motivo por que os dois devem gerenciar a relação. Esse esquema demonstra uma prática de ação de um sobre o outro com o objetivo de um submeter o outro. O saber entra aqui como aquilo que faz o outro submeter-se.

Segundo o autor (2005), toda sociedade é organizada a partir da ideia do bem comum. Essa ação política possui um agente que não apenas elabora um projeto, como ainda se engaja em sua concretização. Se a decisão è coletiva, há a necessidade de um espaço para a discussão e a elaboração desse projeto comum: um representante, que presta conta de seus atos ao grupo, se compromete com a ação, e o coletivo determina os meios para alcançar esse projeto. Grupos organizados (partidos, sindicatos e mídia) são modos de acesso à representação do poder e/ou modalidades de controle. Todo esse espaço de discussão é um espaço da linguagem.

São duas as instâncias implicadas na ação política, segundo o autor (2005): a instância política e a cidadã. A primeira é aquela responsável pela realização da ação política, e a segunda, aquela que escolhe os representantes do poder. Trata-se da teoria da "dominação legítima" de Weber, que abrange inclusive a violência, de modo legal, como meio de submissão à autoridade. A instância política está entre dois polos: a produção comunicativa de um poder legítimo e a busca pela dominação legítima que garante o acesso à própria instância política. O espaço público resultante dessa discussão é o de persuasão em que a instância política procura fazer a instância cidadã aceitar suas ações.

As ideias defendidas nesse espaço público são chamadas por Charaudeau (2005) de valores. Quando os valores são coletivamente apropriados por uma 
entidade, há a criação de uma entidade abstrata - como as noções de Estado, Nação e República - a qual desapropria os indivíduos, tornando-se um terceiro, que é e, simultaneamente, não é o indivíduo.

Esse espaço de criação de valores, citado anteriormente, é o da palavra. Certamente a palavra não é tudo na política, mas fazer política sem a palavra é impossível. A palavra intervém no espaço da ação.

A luta discursiva se dá no âmbito do poder comunicativo, objetivando a legitimidade da ação política por meio da construção de opiniões. E é exatamente por esse motivo que a linguagem se funde à ação. A palavra política está entre a verdade do dizer e a verdade do fazer. A ação se manifesta a partir de uma palavra de decisão resultante de uma discussão em que persuasão e sedução travam batalhas.

Segundo o autor (2005), o que parece ser um terreno comum entre diferentes teóricos é que informação e comunicação estão ligadas nos espaços púbico e privado desde as sociedades antigas. Todos mudam devido à influência de um sobre o outro. Modernamente, a sociedade midiatizada confunde as fronteiras desses espaços por meio da publicização: a esfera privada torna-se exposta ao olhar público e traz ao debate problemas que surgem nesse espaço. O privado torna-se responsabilidade civil.

Charaudeau (2005) afirma que a organização da vida em sociedade é uma atividade política de regulamentação social. Assim se desenvolvem três domínios de ação social: regular, legislar e distribuir. A partir desses domínios surgem quatro estruturas, ou principais lugares, de organização: o jurídico, o econômico, o midiático e o político. O jurídico regulamenta os conflitos sociais e determina valores simbólicos; o econômico regulamenta o mercado determinando valores de troca; o midiático, a circulação da informação, permitindo uma opinião; e, por último, o político estabelece regras de governança, distribuindo tarefas e responsabilidades. Os quatro setores interagem entre si, mantendo relação de interdependência e criando muitas discussões a respeito de quais são suas relações de dependência e autonomia.

A mídia encontra-se em uma posição contraditória, segundo o autor (2005). Isso porque, no mundo político - uma fonte de informação - ela tem um papel importante em sua rede de informações, ao mesmo tempo em que procura se distanciar do poder político numa tentativa de afirmar sua independência.

Com relação ao setor político, ele se encontra bem no meio dos outros setores, fazendo intervenções. A complexidade do setor torna-se ainda maior com a 
influência de instâncias supranacionais, ou seja, instituições internacionais, ditas independentes, que influenciam instâncias nacionais.

O autor conclui que o setor político é "o centro de um sistema em torno do qual gravitariam os satélites que são os outros setores" (CHARAUDEAU, 2005/2013, p.30). Mas o autor complementa que essa estrutura é meramente operatória e que, por isso mesmo, qualquer setor poderia ocupar o centro, fazendo com que os espaços se tornem mais fluídos. Longe de ser homogêneo, o espaço público é fragmentado em vários espaços de confluências e dispersões, contexto em que encontramos o discurso político, constantemente transformado nas influências que recebe.

Analisar o discurso político aproxima noções advindas da Filosofia política e das Ciências políticas, mas não partilha com essas suas finalidades. A Filosofia política diz respeito, segundo o autor (2005), à fundamentação do pensamento político em questionamento dos modelos de organização social, de justiça e direito, de soberania e de legitimidade, tendo por objetivo pensar as formas possíveis de racionalidade política. Já as Ciência políticas questionam a ação política, seu funcionamento e seus efeitos, buscando tornar visíveis os princípios de governança. Os estudos dirigem-se aos atores políticos, a suas práticas, suas identidades e seus engajamentos. A história busca a reconstrução de acontecimentos políticos do passado, explicando suas causas e consequências. Possui conteúdos temáticos e lida diretamente com o tratamento de arquivos.

As análises do discurso político, segundo o autor, buscam questionar os discursos que tornam possíveis a racionalidade política e a regulamentação de seu funcionamento. Sendo universos de valores que emergem num tempo histórico, concentram-se no discurso, nos atos de linguagem que circulam nas esferas sociais e objetivam, como proposto por Foucault, as "formações discursivas" que possam revelar pressupostos na linguagem.

Se um enunciado está ligado ao local de enunciação, então ele pode ser político se a situação autorizar. Dito de outra forma, o discurso só se torna político se a situação de comunicação assim o tornar, posto que é a situação que politiza o discurso.

O autor propõe três lugares de fabricação do pensamento político. O primeiro é o da elaboração do pensamento, atividade discursiva que busca fundar um ideal político a partir do qual opiniões e posicionamentos possam se orientar. São as filiações ideológicas. O segundo é o lugar em que o sentido é realizado pelo ato de 
comunicação, portanto diz respeito aos atores participantes da cena comunicativa e tem como objetivo influenciar opiniões, trazendo adesões e construindo imaginários de filiação comunitária. O último é o lugar em que é produzido o comentário, ou seja, o discurso a respeito do político, não engajando, portanto, o sujeito em uma ação. É, por exemplo, o jornalismo político, que comenta, por exigência, fora do espaço da política e dentro do espaço de cidadania.

Charaudeau (2005) sustenta que esses três lugares não estão separados. O discurso se movimenta livremente entre eles, circulando e atravessando todos os espaços e não permitindo, muitas vezes, que identifiquemos sua origem. O discurso é, simultaneamente, o "lugar de engajamento do sujeito, de justificação de seu posicionamento e de influência do outro" (CHARAUDEAU, 2005/2013, p.43). O discurso político se inscreve em um local em que opinião e verdade se encontram dialeticamente. A palavra que funda e a palavra que organiza a política resultam em um discurso político.

Análises do discurso político se pautam naturalmente mais pelos conteúdos das proposições do que pela maneira como as mesmas proposições são transmitidas. Há um maior foco no logos, do que no pathos ou ethos. Entretanto, Charaudeau (2005) afirma que o discurso tem se deslocado dos argumentos para caminhar à encenação, fazendo com que ethos e pathos assumam o lugar da verdade. Os indivíduos são moldados nas suas relações com o outro; somos, ao mesmo tempo, individuais e coletivos, dialogamos e nos determinamos mutuamente. Nesse jogo de trocas, cada objeto é uma encenação, e a cena política é uma dessas encenações.

O discurso político, segundo o autor (2005), se fabrica em três lugares diferentes. O primeiro é o da governança, no qual a instância política e a instância adversária podem ser encontradas. O segundo é o da opinião, em que encontramos a instância cidadã. $O$ último é a instância midiática.

No lugar da instância política, encontramos primeiramente aqueles que têm poder de fazer, decidir e agir; é o lugar da governança. É comum, nessa instância, a busca da legitimidade para que se alcance esse lugar e aí possa se manter. Estratégias de sedução e persuasão são usadas para obter o apoio dos cidadãos por meio de um consenso social. Esta instância é, segundo o autor (2005), formada por um centro e vários satélites: no centro, estão os representantes do Estado e outros círculos a ele ligados, compostos pelos partidos políticos, pelas instâncias jurídicas, as financeiras, as científicas e as técnicas. Outro círculo, maior ainda, seria o 
composto por organismos supranacionais. Paralelamente à instância da governança e ocupando o mesmo espaço, há a instância adversária, que é, em suas configurações, igual à instância da governança, mas desprovida de poder.

Em seguida, encontramos a instância cidadã, pertencente, segundo Charaudeau (2005), a um lugar em que a opinião está fora do governo. Ela se coloca num lugar que questiona e julga a instância política, produzindo, portanto, o discurso da interpelação do poder governante.

Por último, encontramos a instância midiática, que garante a união da instância política à cidadã. É uma instância que, já legitimada pelo seu papel de informante, busca a credibilidade da instância cidadã. Está, pois, fora da instância política, mas a usa como fonte de informação.

A comunicação política é "uma máquina de forjar discursos de legitimação" (CHARAUDEAU, 2005/2013, p.63) criando imagens de lealdade, protesto e denúncia, associadas respectivamente às instâncias política, cidadã e midiática.

O linguista (2005) afirma que a legitimidade do discurso é um estado ou uma qualidade daquele que o possui, baseada em uma ação bem fundamentada, isto é, reconhecida por outros sujeitos em nome de um estatuto, de um saber ou de um saber-fazer. Quando essa legitimidade se encontra no domínio político, ela é atribuída por um sujeito coletivo, baseada em um sistema de representação: o soberano ocupa um lugar de soberania atribuído por outro poder, acima dele mesmo.

O autor (2005) reconhece três concepções de legitimidade: a legitimidade por filiação, dita herança natural; a legitimidade por formação, que passa por instituições conceituadas, de prestigio, como, as universidades; e por último, a legitimidade por mandato, que vem do povo para representar a vontade comum dos homens, mesmo que em um sistema representativo.

Charaudeau (2005) afirma que o comportamento das massas depende, basicamente, de discursos que contenham ecos de um imaginário coletivo, de crenças. Dentro desse lugar, o político é a voz de todos a qual, ao mesmo tempo, fala para todos, criando, no plano da enunciação, um terceiro; o ideal social, que estaria muito próximo do sagrado, aproximando o discurso político ao religioso.

É possível, então, encontrar dentro do discurso político diversas estratégias. A fala do político, segundo o autor (2005), pode ser orientada por diversos fatores.

O objetivo do discurso político é a persuasão, a adesão dos cidadãos a um projeto ou à ação política. Para isso, ele realiza uma encenação que visa dissuadir, 
do projeto ou da ação de grupos contrários, a instância cidadã. Essa encenação se apoia em um triângulo composto pela afirmação da desordem social, pelo apontamento da origem do mal e pela apresentação da solução salvadora.

Nesse capítulo inicial, traçamos um quadro epistemológico dentro do qual nossa pesquisa circulará. Delineamos a abordagem discursiva como campo teórico de nossa pesquisa, tal como proposto por Foucault. Complementamos o quadro epistemológico ao aproximarmo-nos dos conceitos de episteme e de enunciado em uma perspectiva foucaultiana, além de fazermos uma aproximação com a AD de linha francesa. Por último, buscamos explicitar características e fundamentos do discurso político, objeto de estudo dessa pesquisa. 


\section{CAPÍTULO 2: MÍDIA, SOCIEDADE E OPINIÃO PÚBLICA}

Nosso objeto de estudos é o jornal The New York Times, por isso abordamos, neste capítulo, o funcionamento da mídia e suas relações com a sociedade.

Destacamos, primeiramente, questões que colocam em perspectiva a produção e a recepção das notícias e seu papel dentro do meio que as produz.

A seguir, discutimos a relação da mídia com a sociedade, traçando um paralelo teórico sobre a construção da opinião pública e o papel da mídia. Para isso, resenhamos a tendência do pensamento americano com relação tanto à política externa e ao papel dos Estados Unidos nos assuntos internacionais quanto à maneira como a mídia interfere e forma essa opinião.

\subsection{A ESTRUTURA JORNALÍSTICA: valor, produção e seleção.}

Estudar a mídia é estar em um amplo espectro de relacionamentos com outros discursos. Como mencionado no capítulo anterior, Charaudeau (2005) afirma ser a mídia inerentemente contraditória por situar-se entre a sua independência e a necessidade de fontes de informação advindas de vários lugares. A mídia é, segundo o autor (2005), aquilo que regulamenta a circulação da informação e o meio pelo qual se permite a criação de opiniões. Há efetivamente um relacionamento entre a mídia e seu público leitor, como também há uma relação da própria mídia com seus meios técnicos e ideológicos. A esse conjunto de relações dá-se o nome de valor.

Golding e Eliot (2009) analisam, em um primeiro momento, o que é chamado de valor das notícias. Segundo os autores, o conceito de valor pode ser usado de duas formas distintas: uma, referindo-se à seleção do material, dentro de um conjunto disponível, que se transformará em produto final; a outra, que se relaciona às ênfases, às omissões e às prioridades na preparação das notícias.

Os autores (2009) afirmam que há pressupostos implícitos na atribuição de valor à notícia. Em primeiro lugar, há o pressuposto do público, cujo fundamento é a notícia ser interessante, relevante e entendida. Em segundo, o da acessibilidade, pois 
a notícia deve ter proeminência e facilidade de cobertura. Por último, o pressuposto da adaptação da notícia às rotinas pragmáticas de produção. Em resumo, os autores atribuem o valor da mídia em consonância com o público e com os meios jornalísticos.

Golding e Elliott (2009) atribuem ao jornalismo os mesmos valores das histórias. Histórias jornalísticas são ao mesmo tempo histórias e notícias. As boas histórias possuem raízes nas estruturas narrativas do drama humano: têm começo, meio e fim e provocam, nas palavras de Reuven Frank, ex-presidente da NBC, alegria, tristeza, choque e medo.

Pensando em jornalismo como uma narrativa, a estrutura dramática, segundo Golding e Elliott (2009) é alcançada por meio da apresentação de um conflito, normalmente opondo pontos de vista e cobertura pelos jornalistas dos dois lados da questão. Sendo assim, o público, a quem é apresentado um interessante confronto de pontos de vista, tem a impressão de estar em contato com toda a história.

Além da estrutura dramática, não podemos esquecer que a história possui o caráter de entretenimento. Como entretenimento, a notícia serve, segundo os autores, ao prazer do público, que não procura apenas aquilo que é feliz. O interesse humano se manifesta também no bizarro, nas tragédias, na guerra e no frívolo. Esse ponto é crucial para o entendimento de que o jornalismo se estabelece entre seu papel de informar e o desejo público de diversão. Os autores enxergam o entretenimento, amplamente compreendido, como a prioridade do jornalismo, sendo ele mesmo um objetivo ou um meio de alcançar outras ideias.

$\mathrm{Na}$ produção da noticia, três fatores são essenciais. Primeiramente, a importância do que é publicado, uma vez que, de acordo com os autores (2009), ela se baseia no interesse do maior número de pessoas, levando ao público aquilo que as pessoas querem e precisam saber. Nesse sentido, Golding e Elliot (2009) ressaltam que o papel social do jornalismo é ser uma espécie de tribuna do povo, valoração que também pode ser estendida à notícia já que o tamanho e a frequência dela seguem o mesmo critério de importância e relevância.

Em segundo lugar, Golding e Elliott (2009) explicam que a importância do que é publicado deriva também do publico e do critério de acessibilidade, conforme anteriormente citado. Sendo assim, o evento, não necessariamente uma história doméstica, é partilhado entre a experiência do jornalista e a do leitor, constituindo, portanto, um universo cultural compartilhado, e não apenas geográfico.

Em terceiro lugar, os autores (2009) destacam a brevidade da notícia. 
Notícias carregadas de fatos tendem a ser mais breves e, assim, mais relacionadas ao papel mais informativo e menos explicativo do jornalismo.

Quanto à seleção, Golding e Elliott (2009) afirmam que as notícias estão relacionadas a rupturas no curso normal dos eventos, por isso o caráter negativo delas. Dessa forma, a mídia torna-se uma espécie de vigilância social que aponta rupturas no sistema seja político, seja econômico, seja ainda social.

A questão do valor está também relacionada a outro aspecto: a personalização, uma vez que as notícias tendem a ser sobre indivíduos. Visando a mais compreensão, os processos complexos usados nas notícias são substituídos por processos mais simples, como a substituição de instituições ou países por indivíduos. Ao colocar o foco no indivíduo, a ação torna-se mais concreta, e não abstrata como seria no caso de uma instituição.

Os autores ainda analisam questões, como tendência, objetividade e ideologia. Eles apontam que a tendência está muito mais próxima do grupo do que do indivíduo. Já a imparcialidade e a objetividade também são vistas de formas diferentes: a imparcialidade está associada a uma seleção de material sem privilegiar um ponto de vista ou opinião; a objetividade está em um patamar acima por relacionarse a limitações inerentes ao processo. Essa visão leva à possível conclusão de que a imparcialidade existe, mas a objetividade é intangível. Outra visão, como a defendida por Carmagnani (1996), coloca os dois conceitos como impossíveis no jornalismo.

Com relação à questão ideológica, Golding e Elliot (2009) afirmam que o noticiário é ideológico em três perspectivas diferentes. Numa perspectiva, a notícia foca em instituições que são palcos políticos onde conflitos sociais são administrados e resolvidos. Outra perspectiva ideológica se revela na demanda da notícia por imparcialidade e neutralidade, qualidades que se aproximem da noção do senso comum, e isso é ideológico. A terceira, e última, perspectiva ideológica está no fato de a mídia mostrar um mundo fixo e estático nas notícias. Isso se dá, porque histórica e institucionalmente a mídia falha ao fornecer ou mostrar processos de mudanças sociais devido, principalmente, à sua preocupação com o presente.

Uma questão presente nos estudos da mídia é aquela que faz um fato virar notícia. Há infinitos acontecimentos no mundo que nos cerca, alguns dos quais viram notícias e outros, não. Uns se tornam tópicos de discussão nos jornais, nas televisões e nas mídias sociais; outros são completamente ignorados e não se tornam públicos. O fato em si não determina o estatuto de notícia, pois a característica de uma notícia 
não está no acontecimento, mas sim fora dele. Golding e Elliot (2009) afirmam que notícias não são notícias por elas mesmas, isto é, não há uma propriedade intrínseca no fato que o faz notícia. Toda seleção é um movimento complexo que obedece a um conjunto de categorias socialmente construídas. Em todo momento, bilhões de eventos acontecem no mundo, e todos eles são notícias em potencial, mas poucos se tornam notícias. Tudo é uma questão de seleção.

Uma das primeiras evidências de que há seleção nas notícias é que os jornais estão vinculados a um tipo de público e de região. O valor informativo começa a estruturar o processo a partir da definição do que é notícia para um grupo de profissionais.

Outro aspecto relevante, segundo os autores (2009), é a construção da estória midiática. Ela envolve como um fato é apresentado para seu suposto público, pois todo evento só faz sentido se localizado dentro de um campo de identificações conhecidas e construídas socialmente.

As notícias são selecionadas, porque representam, como afirmamos anteriormente, uma imprevisibilidade e um conflito em certa natureza do mundo. Trazer um evento para uma realidade significa encaixá-lo em um mapa de sentidos conceituais de uma determinada cultura, processo esse que torna o evento inteligível.

O processo de significação social que a mídia produz e reproduz, segundo os autores (2009), é um construto social, como um "consenso". Ao falar sobre cultura, observamos a crença, cada vez mais difundida e altamente ideológica, de que ela permeia uma ideia de sociedade, ou seja, ao pertencer à mesma cultura os indivíduos são parte da mesma sociedade. Nesse mundo, só existiria uma perspectiva dos eventos, aquela que condiz com os valores centrais da cultura e do interesse comum. Assim como a lei, que a todos protege igualmente, a mídia parece assumir a posição de mediadora cultural. Fatos e notícias são interpretados em uma estrutura que deriva dessa noção consensual.

Segundo Hall (2009), a mídia representa a fonte primária, e muitas vezes a única, de muitos eventos importantes. Por tratar daquilo que é novo e inesperado, ela lida com uma realidade problemática que abala a ordem e a rotina. Exatamente por estar fora da estrutura, esse abalo pode ser considerado de difícil compreensão, quando assume, então, a função de transformar o fato em algo inteligível. Isso dá ao leitor um poderoso instrumento, claramente orientado, de como o fato deve ser interpretado. 
Mas, ainda conforme Hall (2009), existem fontes primárias e secundárias que definem as notícias. Em primeiro lugar, a mídia não está sozinha na atribuição de valores interpretativos, pois, não criando autonomamente as notícias, ela é estimulada por fontes (instituições) regulares e confiáveis. Em seguida, porque objetiva imparcialidade, objetividade e balanço nas informações, jornalistas buscam fontes delimitadas ideologicamente por suas instituições.

Na pressão e urgência de produzir notícias, a mídia tende a reproduzir fiel e "imparcialmente" as estruturas institucionais de poder. O resultado dessa tendência é a criação das fontes primárias, nos termos de Hall "definidores primários", responsáveis pela interpretação primária dos fatos e dos eventos, chamados de estrutura inferencial. Outro ponto ressaltado pelo autor é que o debate de um tópico por várias instâncias é uma forma de dramatizar um evento para garantir seu valor de notícia.

Para Hall (2009), a mídia não é a única fonte em todo esse processo. A mídia não cria, em si mesma, as notícias por não ser o definidor primário das notícias. Ela se liga a fontes diversas, normalmente dominantes, e consequentemente transmite suas ideologias. Podemos dizer que por causa de sua relação estrutural com o poder, ocupa um lugar de reprodutor, desempenhando então um papel secundário.

\subsection{A RECEPÇÃO JORNALÍSTICA: público leitor, circulação e sociedade}

Quando concebemos a ideia de mídia, levamos em consideração a existência de um público. Consequentemente, indagamos qual é essa ideia de público, uma vez que ele é parte da existência da própria mídia. Para analisarmos quem é esse público, seguimos as ideias propostas por Gabriel Tarde (1992) em sua Psicologia do público.

Tarde (1992) afirma que precisamos fazer distinção entre público e multidão, dois termos diferentes para a "evolução social". Para o autor, a noção de público só aparece com a invenção da imprensa no século XVI, pois é nesse momento que se estabelece uma nova relação com a leitura, que passa a ser cotidiana e coletiva. $\mathrm{Na}$ leitura, o autor afirma que novas opiniões ou atitudes preexistem aos seus criadores e que elas são meramente "reveladas", pois já estavam em circulação na sociedade. 
Para o autor (1992), a grande conversão das massas passa da oralidade, da praça pública para o escrito. Assim sendo, os jornalistas são, hoje, os responsáveis por essa conversão, que não se dá, ainda de acordo com o autor, de modo singular, pois os diversos jornais servem de antídotos de uns para os outros.

Tarde (1992, p.59) também declara que "a opinião está para o público, nos tempos modernos, assim como a alma está para o corpo". Segundo o autor, a tradição vem antes da opinião: os indivíduos de uma sociedade possuem primeiramente uma tradição em comum e, a seguir, desenvolvem uma opinião a partir de certo momento posterior à tradição. $\mathrm{O}$ autor define a opinião como um:

"grupo momentâneo e mais ou menos lógico de juízos, os quais, respondendo a problemas atualmente colocados, acham-se reproduzidos em numerosos exemplares de pessoas do mesmo país, da mesma época, da mesma sociedade" (TARDE, 1992, p.63).

Dessa maneira, percebemos que a opinião individual torna-se coletiva, na antiguidade, pela palavra pública e, nos dias de hoje, pela imprensa.

O sociólogo (1992) conclui que o jornalismo teve um papel transformador: nacionalizou e, até, internacionalizou aquilo que chama de espírito público. $O$ jornalismo é, continua o autor (1992, p.89), uma "bomba aspirante-premente de informações" espalhadas ao longo do globo, "impulsos gradativamente irresistíveis" que, aos poucos, modelam discursos e impõem a eles a maior parte de seus assuntos. A impressa pode mudar uma forma de governo e um monarca, os quais não mais constituem a unidade e a consciência de uma nação: a unidade passa a existir fora do governo, em conformidade com uma consciente opinião nacional. Sendo assim, o político curva-se a ela.

A imprensa é hoje a unificadora das conversações, uniformizando o espaço e diversificando o tempo. É ela que nos dá, todos os dias, os tópicos de nossas conversações, mudando toda semana, salvo quando há um caso de obsessão nacional ou internacional. Ao analisar a evolução da "conversação", o autor afirma que a conversa (vida de salão), nas sociedades mais "cultivadas", segue um guia proposto pela imprensa.

Segundo Thompson (2009), o homem se ocupa da produção e da troca de informações em todas as sociedades e em todos os tempos. Elas são centrais na vida social, pois a produção, o armazenamento e a circulação de informações e de 
conteúdos simbólicos são significativos para os indivíduos. Essa produção mediada é, para Thompson (2009), um fenômeno social contextualizado, sendo complexos os mecanismos de condições sociais que perpassam a produção e a circulação de mensagens.

A vida social, segundo o autor, é formada de indivíduos que buscam fins e objetivos variados. Sendo assim, eles agem em um dado conjunto de circunstâncias ou "campos de interação" (ou de uma instituição), dentro dos quais podem ocupar diferentes posições, sempre ligadas ao poder que eles possuem. No exercício do poder, os indivíduos empregam os recursos que lhes estão disponíveis a fim de alcançar seus objetivos. Esses recursos são, na perspectiva do autor, controlados institucionalmente. Visto por esse ângulo, o poder é um aparato social que subjaz a diferentes tipos de ações.

O autor (2009) distingue quatro tipos de poder: o econômico, o político, o coercivo e o simbólico. Para fins do presente capítulo, focalizamos o quarto tipo, o simbólico, por estar presente em instituições culturais como a mídia.

A atividade simbólica é fundamental na vida social. Por meio dela, o individuo se expressa e interpreta a expressão do outro, em um constante movimento de trocas simbólicas. Nessa produção simbólica de prestígio acumulado, chamada por Bourdieu (1986 apud Thompson 2009) ${ }^{5}$ de "capital cultural", o individuo, para realizar suas ações, se serve de fontes, que são recursos de produção, transmissão e recepção de informações e de conteúdos simbólicos. Esses recursos são normalmente creditados a produtores e a instituições de capital cultural. O autor (2009) se utiliza do termo "poder simbólico", tomada de Bourdieu $(1991)^{6}$, para referir essa capacidade de intervir e influenciar nas ações dos outros e nos acontecimentos.

Essa normalização, gerada pelo discurso, transforma-se num "corpo político", que, na perspectiva foucaultiana, pode ser assim entendido:

(...) conjunto de elementos materiais e das técnicas que servem de armas, de reforço, de vias de comunicação e de pontos de apoio para as relações de poder e de saber que investem os corpos humanos e os submetem fazendo deles objetos de saber. (FOUCAULT, 1975/2000, p.27)

\footnotetext{
${ }^{5}$ BOURDIEU, P. "The form of Capital", in J.G. Richardson (ed) Handbookof Theory and Research for the Sociology of Education. Westport: Greenwood Press, 1986.

${ }^{6}$ BOURDIEU, P. Language and Symbolic Power. Cambridge: polity Press, 1991.
} 
A partir da estruturação dessas normas políticas, o sujeito, ao mesmo tempo em que ganha "saber", insere-se numa ampla rede de poder. Foucault (1975) assere que "na região mais sombria do campo político, o condenado desenha a figura simétrica e invertida do rei" (FOUCAULT, 1975/2000, p.28).

Conforme Thompson (2009), a caracterização do mundo moderno começou na Europa no final da Idade Média. Novas instituições e novas ações sociais surgiram, delimitando novas convenções e novas formas de associação. Todas essas transformações foram decorrentes de um conjunto de mudanças: no âmbito econômico, o feudalismo se transformou em um novo sistema, o capitalismo, enquanto que, no âmbito político, observou-se a formação dos estados-nações.

A formação dos Estados modernos relaciona-se com a criação de símbolos e sentimentos de identidade nacional. O surgimento de um Estado forte é precedido pela formação de um forte sentimento de identidade nacional, com a força de um poder simbólico.

Para o autor (2009), as organizações tipográficas surgem, no início da Europa Moderna, como instituições culturais e econômicas, abarcando, em suas estruturas, intelectuais, eruditos e clérigos. A indústria editorial cria, então, novos centros e novas redes de poder simbólico, independentes dos poderes político e simbólico então controlados por Estados e Igrejas. De fato, Estado e Igreja procuravam usar a indústria editorial para seus próprios benefícios, mas de maneira muito limitada. Um grande exemplo dessa limitação é a Reforma, quando as novas técnicas de impressão tiveram papel importante na divulgação das ideias de Lutero.

Trazer a questão da mídia para a contemporaneidade faz perceber, como afirma Bucci (2009), que as verdades são construídas pela imagem e que, quando há um ataque à imagem, também ferimos a verdade. Nossa sociedade se define e se reconhece na imagem: a verdade é socialmente construída pelos olhos, e são neles que ela adquire dimensão social. Um grande exemplo da fabricação da verdade pelo olhar é o 11 de setembro, que marca, de acordo com o autor (2009), a "lógica do terror dentro da lógica do espetáculo" (2009, p.67). É inicialmente na dimensão do olhar que, após o 11 de setembro, uma nova ordem se estabelece. Bucci (2009) ainda afirma que a produção de imagens, assim como a circulação e a produção de mercadorias, passa por um momento capitalista em que o culto à imagem transforma-se em uma nova forma de mercadoria. A materialização do olhar é composta por uma relação complexa de desejo, capital e poder. As guerras, após o 11 de setembro, 
reconfeccionam verdades para o olhar, pois colocam no plano do olhar novos processos de significação, dando sustentação para o herói ferido recompor sua imagem.

Bucci (2009) considera que a guerra em nosso tempo é, por si só, um ato de comunicação em que as verdades se compõem ao mesmo tempo, nem a priori, nem a posteriori. O estrangulamento do jornalismo hoje é uma premissa da guerra: "A guerra só pode ter início quando a verdade (jornalística) já foi vitimada." (2009, p.81)

A verdade na sociedade contemporânea não é simplesmente uma construção, mas é também o desejo na instância do olhar, o qual, inconsciente, ordena o visível. Nesse sentido, a verdade jornalística é uma modalidade discursiva específica, apoiada em um instrumental metodológico e prático, que: em primeiro lugar, precisa ser comprovada por qualquer um do público; em segundo, não pode se pretender eterna; e, por último, deve obedece a um nível elementar de racionalidade. Bucci (2009) concebe que, na contemporaneidade, a verdade jornalística um componente do espetáculo.

\subsection{A TESSITURA JORNALÍSTICA: opinião pública e influências.}

Como dissemos anteriormente, um dos grandes norteadores das ações políticas é a opinião pública. Há, nos Estados Unidos, uma grande tradição de pesquisas que buscam medir e embasar a viabilidade de uma ação. Grandes institutos de pesquisa e universidades empenham-se em compreender as tendências comportamentais ou de pensamento que acompanham os americanos.

Wittkopf (1996) declara que, nos últimos anos, muito se tem discutido sobre qual seria o papel apropriado dos Estados Unidos nos assuntos mundiais. Duas tendências distintas são apontadas no âmbito da ação do país em questões internacionais: a internacionalista e a isolacionista. Para esse autor, algumas pesquisas recentes têm demonstrado que os americanos estão se voltando para dentro, rejeitando a liderança imposta na última metade do século.

Ainda esse mesmo (1996) aponta que, no final da guerra fria, os americanos repensavam o papel dos Estados Unidos no mundo, pois a guerra exigiu um gasto extraordinário; e repensar, para Wittkopf, não significa rejeitar. Segundo o autor, os 
americanos são questionados desde 1940 sobre se eles acham que o melhor futuro para o país é um papel ativo nas questões internacionais, ou se o país deve se manter fora das questões.

Essa contradição entre internacionalismo e aprendizado advindo da experiência de participação em outras guerras pode ser explicada por uma estrutura de crenças que resiste a dramáticas mudanças globais.

O internacionalismo tem duas faces, uma cooperativa e outra militante. Após a guerra do Vietnã, as duas faces se revelaram: uma, em mudanças particulares: e outra, baseada em um ethos nacional e na percepção de segurança. E como o internacionalismo, conforme ainda o autor, tem duas faces, as coalisões dependem do assunto em questão e refletem a ideologia política e as crenças em políticas externas.

O autor (1996) também afirma que os líderes têm a habilidade de moldar as percepções do público e assim estimular o apoio e as coalisões. A liderança é a estrutura e o propósito que guiam a política externa americana, e o patriotismo predispõe os americanos a seguirem as iniciativas dos lideres. As atuais vozes internacionalistas e isolacionistas atestam uma constante busca por estrutura e propósito na nova (dis)ordem mundial. Entretanto, os americanos não estão à deriva; ao contrário, estão fortemente ancorados em uma tradição internacionalista que se prova extremamente forte.

Matthew Baum e Philip Potter, no artigo The relationship between mass media, public opinion and foreign policy: towards a theoretical synthesis (2008), discutem de que modo o público desenvolve o pensamento e a opinião sobre a política externa e analisam suas possíveis influências. A partir de uma revisão de trabalhos recentes na área, esses autores estabelecem um modelo baseado no conceito de equilíbrio de mercado, considerando três atores: lideres, público e mídia.

Revisando outros trabalhos, Baum e Potter (2008) consideram que as lideranças seguem dois pressupostos. Primeiro, o de que a mídia falha ao transmitir as informações que deve e, segundo, o de que a mídia molda a opinião pública sobre assuntos externos, transmitindo passivamente a visão da elite.

Os autores, estabelecido o objetivo de entender as relações multifacetadas entre todos esses atores e de ligá-las aos resultados obtidos na política externa, perguntam se mídia é uma variável na formação da opinião pública, ou se é uma 
agregadora das mensagens da elite, como a literatura das ciências políticas muitas vezes indica.

Baum e Potter (2008) destacam que a mídia influencia quase todos os aspectos na relação da política externa com a opinião pública, mas que qualquer modelo teórico necessita incorporar uma abordagem interdisciplinar que enxergue a opinião pública, a mídia e as preferências das elites como formas independentes.

Também afirmam que as relações estabelecidas entre lideranças, mídia e opinião pública são, em muitos aspectos, análogas à clássica noção econômica tanto de mercado de oferta e demanda, quanto de produtores e, ainda, de consumidores. Para os autores, a informação é uma commodity de mercado estabelecida por esses três atores. Tipicamente, as informações favorecem as lideranças, entretanto, em algumas dinâmicas, podem fazer com que o público supere sua desvantagem na informação, produzindo, em consequência, um equilíbrio a curto e longo prazos. Assim, os autores defendem o conceito de equilíbrio como uma forma de conceituar o processo de formulação da política externa.

Analisando os atores do processo a partir de dados mais recentes, os autores (2008) entendem que, em uma democracia, o público tem a capacidade de reunir, reter e usar informações para formular opiniões coerentes, o que o torna mais estável e consistente. Afirma-se consensualmente que o público é capaz de desenvolver opiniões coerentes sobre política externa e aplicá-las a decisões eleitorais, levando os políticos a considerarem suas decisões acerca da política externa para fins eleitorais.

Baum e Potter (2008) consideram que a busca de informações, tanto a curto quanto a longo prazos, pode ser explicada pelas mesmas leis de mercado anteriormente citadas. Sob desvantagem de informações, o público utiliza a visão das elites como um atalho cognitivo que protege o interesse comum (rally-round the flag), mas isso ocorre somente se não houver evidências da falta de credibilidade. A influência pública parece ser a mais fraca quando a informação é fraca, principalmente em situações de início de conflitos.

A seguir, os mesmos autores (2008) analisam a dinâmica dos decisores ${ }^{7}$ políticos e como esses reagem às demandas do mercado. Quando a opinião pública é fraca devido à ausência de informação, há uma tendência, afirmam os autores, a

\footnotetext{
${ }^{7}$ No original encontramos a expressão "decision makers". Optamos pela tradução "decisores", presentes em alguns textos em português, mas ainda não dicionarizada.
} 
usar o conflito para manipular a opinião pública. Conflitos, especialmente o uso da força, podem ser avaliados para alavancar campanhas eleitorais, ou desviar a atenção de problemas domésticos. Em alguns casos, quando a liderança não está certa de sua reeleição, o envolvimento em conflitos externos é evitado. Baum e Potter (2008) afirmam que, na visão da política de mercado, a ideia de desvio é um espelho do conceito de interesses comuns: se um conflito não perdurar, poderá afetar negativamente a opinião pública. Todo conflito tende a diminuir a distância entre lideranças e público, tanto aumentando a busca por informações, quanto direcionando, muitas vezes, o público contra o conflito.

Com relação ao papel da mídia nessa dinâmica, vista como um importante commodity de mercado, os autores (2008) afirmam que ela possui o papel fundamental de coletar, enquadrar e distribuir informações. Os autores consideram que as lideranças valorizam muito a posse desse commodity, ao buscar o controle e o domínio da mídia. Duas visões podem ser aplicadas: uma, que enxerga a mídia como um index da retórica da elite, e outra, que a vê mais independente.

O equilíbrio das informações tende a favorecer os líderes, exceto se isso falha ao observar certas dinâmicas de mercado em que o equilíbrio pode alternar lideranças e público. No âmbito da politica externa, a mídia possui papel essencial na mudança de dinâmicas, pois a principal ligação entre lideranças e público é a mídia, central nesse mercado político posto que ela funciona como mediadora no fluxo de informações quando há conflito de interesses. A mídia situa-se entre duas posições distintas: por um lado, o fornecedor de informações da mídia são as lideranças, que organizam aquilo que deve ser veiculado; por outro, ela também está atenta às demandas do público, que é seu real consumidor. Baum e Potter afirmam que entender como a mídia responde à pressão desse competitivo mercado é a chave para o entendimento do processo dinâmico das políticas externas.

Por fim, Baum e Potter sintetizam e definem o que chamam de Mercado de Política Externa (termo apropriado das Ciências econômicas). Eles afirmam que é necessária uma incorporação mais efetiva do papel da mídia nos modelos teóricos. Dois lados, lideranças e público, estão interessados na criação de políticas que atendam a seus interesses. A habilidade de influenciar essa decisão varia de acordo com a quantidade de informação que cada ator possui, embora as lideranças pareçam estar em vantagem nesse quesito, permitindo, consequentemente, que ditem a politica externa. Um terceiro ator, a mídia, funciona como negociador de informações, 
atendendo à demanda de seus consumidores e moldando as informações de acordo com o interesse das elites, por isso a mídia fica em uma linha tênue entre os moldes das elites e o interesse de seu público. Segundo os autores, os resultados da política externa emergem do delicado equilíbrio dessas duas forças competitivas.

Os autores (2008) concluem ser necessário um refinamento para explicar as relações entre público e políticas externas. Os modelos conceptuais devem elevar a mídia de um papel de aglutinador dos interesses das elites a um ator estratégico independente, uma arena de luta de interesses. Com a abordagem do equilíbrio do mercado, Baum e Potter afirmam que podem retirar as análises políticas de um modelo linear, que predomina nas literaturas, e transformá-las em conceitos mais verdadeiros e frutíferos.

Nesse capítulo, apresentamos um estudo sobre a mídia o qual permite compreender a estrutura jornalística vista em uma perspectiva do valor, da produção e da seleção daquilo que se torna notícia. Vimos que a mídia está inserida em um universo cultural que determina a seleção. Sendo assim, a notícia obedece a categorias socialmente construídas, tornando-se ideológica.

Percebemos que não há nada em um fato do mundo que o transforme em notícia. A seleção acontece no exterior do fato, nas fontes externas ideologicamente construídas.

Discorremos também sobre a questão da recepção, ou seja, sobre a intima relação entre a imprensa e o público: os indivíduos, em sua prática política, buscam recursos disponíveis para o exercício do poder. Um desses recurso está presente em símbolos construídos por instituições culturais como a mídia. Esses símbolos estão em consonância com o sentimento de identidade nacional e constroem verdades, cujas imagens são criadas, mantidas ou alteradas.

Por fim, observamos a relação entre opinião e mídia. Vimos que a mídia funciona como uma espécie de commodity que faz com que as lideranças busquem o seu controle, tonando-se, assim, uma arena de lutas. 


\section{CAPÍTULO 3: A GUERRA NA SÍRIA: PERSPECTIVAS CRÍTICAS, SOCIAIS E HISTÓRICAS}

Este capítulo apresenta as perspectivas críticas, sociais e históricas sobre a guerra na Síria e sobre as relações entre Estados Unidos e Oriente. Na primeira parte, concentramos nossos estudos na relação estabelecida entre Ocidente e Oriente, focando principalmente as relações estadunidenses com o Oriente Médio. Procuramos compreender tanto as tendências gerais da política externa americana voltada principalmente para o Oriente Médio quanto a forma pela qual o Ocidente retrata o Oriente.

Na segunda parte, nossa atenção recai sobre o contexto inicial da Primavera Árabe. Iniciamos por um panorama geral dos eventos ocorridos em um dos países envolvidos no que se convencionou chamar de Primavera Árabe. A seguir, desenhamos um panorama mais específico sobre a história da Síria, país alvo de nossos estudos, e sobre as características de sua primavera árabe.

\subsection{RELAÇÕES OCIDENTE E ORIENTE: uma perspectiva externa}

Visando estabelecer as diferenças entre, de um lado, os conceitos de imperialismo e de colonialismo e, de outro lado, a noção de império, iniciamos esse capítulo abordando teorias que, de forma complementar, buscam compreender suas diferenças e semelhanças.

De acordo com Said (1994), imperialismo é a prática, a teoria e a atitude de um centro metropolitano que influencia territórios distantes, enquanto que colonialismo, sempre uma consequência do imperialismo, é a implantação de colônias econômicas, culturais e sociais em territórios distantes. Império é uma relação formal ou informal em que um controla a soberania política do outro, decorrendo dessa relação a noção de subjugado. Há em império uma ideia metafísica de protetorado, que regra pessoas inferiores ou menos avançadas. 
Michael Hardt e Antonio Negri chamam de Império a forma atual da economia mundial, em que a soberania do Estado-nação é colocada em xeque por sua incapacidade de regular as trocas econômicas e culturais. A palavra Império é assim usada metaforicamente, não estabelecendo fronteiras nem nações, para se referir a um "aparelho de descentralização e desterritorialização do geral que incorpora gradualmente o mundo inteiro dentro de suas fronteiras abertas e em expansão." (HARDT M.; NEGRI, A., 2001, p 12)

Segundo os autores, o poder do Império tem alcance em toda a ordem social:

O Império não só administra um território com sua população, mas também cria o próprio mundo que ele habita. (...) O objeto de seu governo é a vida social como um todo, e, assim, o Império se apresenta como forma paradigmática de biopoder. (HARDT M.; NEGRI, A., 2001, p.15)

A origem desse Império, na percepção dos autores, constituiu-se juridicamente, havendo, para isso, um papel essencial da ONU, que, criada a princípio para manter a segurança mundial, acaba por promover um "constitucionalismo global".

A Declaração Universal dos Direitos Humanos é um exemplo desse constitucionalismo "imperial". Clark (1997) entende que a declaração, dominada por preocupações, interesses e valores de um segmento bastante pequeno das Nações Unidas, formata ideias acordadas por nações ricas, como Estados Unidos, Inglaterra e França. Trata-se de uma declaração que, para o autor, enfatiza direitos políticos enraizados na longa história desses países, razão por que pouca atenção é dada aos direitos econômicos, sociais e culturais.

Dentro desse contexto, uma das questões bastante discutidas é o papel da ONU no processo de governabilidade mundial. É importante ressaltar que a ONU, não sendo uma instituição independente por viver de subsídios de seus países membros, em especial dos americanos, ela só age positivamente se as grandes potencias assim permitem. E o papel da ONU não se restringe ao campo da ação; estende-se também ao ideológico. Por essa razão, o conceito de "democracia", por exemplo, advém de um modelo americano que, por força econômica e política, é tomado como modelo pela ONU. Assim, qualquer outra forma de organização social que não seja compatível com esse conceito é chamada de tirania. Note-se que impor à força a democracia americana não seria tirania. 
Hardt e Negri (2001) rejeitam a ideia de que a globalização é uma continuidade ou um aperfeiçoamento do imperialismo. Para eles, os conflitos e as competições entre as nações foram substituídos pela ideia de um poder único, que, estando acima de qualquer nação, organiza uma estrutura unitária. Os autores ainda dão especial atenção e, consequentemente, importância à comunicação como organizadora desse processo de globalização em que a mídia e a linguagem ocupam evidentemente espaços de destaque.

Um lugar onde deveríamos localizar a produção biopolítica de ordem é nos nexos imateriais da produção de linguagem, da comunicação e do simbólico que são desenvolvidos pelas indústrias da comunicação. (...) A comunicação não apenas expressa, mas também organiza o movimento de globalização. (...). Expressa o movimento e controla o sentido de direção do imaginário que percorre essas conexões comunicativas; em outras palavras, o imaginário é guiado e canalizado dentro da máquina de comunicação." (HARDT, M.; NEGRI, A. 2001, p.51)

Investigando a natureza da soberania americana, Hardt e Negri (2001) afirmam que ela precisa ser compreendida a partir de sua formação, ou seja, da revolução americana. A soberania americana se forma união de uma rede de poderes constitucionais na qual equilíbrio e controle mútuos são mantidos pelas mãos da multidão e constituem um poder central. Há vários mecanismos institucionais que, embora diversos, não se distanciam da unidade, criando uma forma de poder estável.

São três as características da noção americana de soberania. A primeira traz uma ideia de "imanência do poder", colocando-o dentro do corpo social. Além dessa, há a ideia protestante do poder produtivo da multidão, a qual demonstra a existência de Deus e Sua presença na terra. Nesse sentido, o poder não nos coloca em posição subserviente, mas é construído por nós mesmos. A segunda característica é a finitude, que, resultando do caráter conflituoso da multidão, funciona como uma sempre antítese dialética, um ponto de crise. Finalmente, a terceira, resultante das demais, refere-se ao projeto, aberto e expansivo, que opera em lugar ilimitado. Diga-se que a expansão, no projeto americano, é inclusiva, pois, ao expandir, não destrói o outro, mas o inclui em sua rede. Os autores (2001) afirmam que o Império é uma "república universal", uma espécie de espaço infinito onde operam poderes e contrapoderes numa só estrutura, ilimitada e inclusiva. 
Dessa forma, é possível perceber na história americana, ainda de acordo com os autores (2001), o desenvolvimento da noção de soberania e de suas características.

O primeiro período, que vai da independência americana até a Guerra Civil, pode ser visto como um processo aberto de construção coletiva, livre de formas de centralização e hierarquias. O novo país, estando livre do peso histórico e aristocrático Europeu, tem como único obstáculo a natureza. Nesse primeiro momento, os Estados Unidos vivem a utopia de ser um espaço aberto, onde a liberdade torna-se soberana. Nesse momento, a Guerra Civil americana torna-se a primeira contradição interna, pois a escravidão era uma barreira à soberana liberdade e à formação de um povo livre. Assim, os constitucionalistas do Sul foram a primeira crise da estrutura soberana da nação. Nesse cenário, Abraham Lincoln acaba com o peso da escravidão e refunda a nação, recriando uma nação de homens livres.

O segundo período, que vai da era progressista até a virada do século marca, segundo os autores (2001), o final do período anterior que chega ao seu limite. Principalmente a luta e a divisão de classes constituíram um limite ao expansionismo americano. As respostas ao limite que a luta de classes estabelecia vieram como uma espécie de progressismo nos governos Roosevelt e Wilson. Era necessário conter a luta de classes e a corrupção dentro das redes de poder. Ambos os governantes reconheciam que o antagonismo na luta de classes era impossível de ser apagado, por isso, motivado pela ânsia expansionista, Roosevelt se envereda para um imperialismo colonial, como, a colonização das Filipinas, enquanto que Wilson trilha um caminho mais internacionalista e se coloca a serviço de uma extensão do projeto constitucional americano para o resto do mundo. Assim fazendo, emerge uma espécie de governo mundial da paz, o que, segundo os autores (2001), constitui um eficiente promotor da passagem para o Império.

O terceiro período abrange desde o New Deal até o auge da guerra fria, quando a ambiguidade americana aparece de maneira muito intensa. Essa ambiguidade se expressa, no dizer dos autores (2001), na expressão "proteger ou dominar". Torna-se impossível distinguir a proteção que os americanos queriam oferecer ao mundo contra o comunismo da dominação e exploração desse mesmo mundo por meio de técnicas imperialistas. O Vietnã é o maior exemplo desse período, encerrado pela guerra e sucedido por um novo regime constitucional. 
Segundo Hardt e Negri (2001), o quarto período começa com os movimentos sociais dos anos 60 e se estende até a queda do bloco soviético. Sendo a União Soviética vítima de suas próprias contradições internas, abre-se um espaço de visibilidade do projeto imperial americano.

Com o final da guerra fria, aparece a responsabilidade americana de exercer um poder de polícia internacional, e a Guerra no Golfo é a primeira materialização desse exercício. Nasce, conforme os autores (2001), uma nova ordem mundial, um interesse que age não de forma imperialista, mas sim imperial. Os Estados Unidos são chamados para garantir a eficácia jurídica da formação de um novo direito supranacional com base em normas jurídicas internacionais que aumentariam uma forma de poder hegemônico. Assim é que os Estados Unidos passam a intervir militarmente em todos os conflitos, sempre sob a justificativa de garantir a ordem e a paz mundial.

Hardt e Negri (2001) consideram que a constituição americana é imperial, e não imperialista. Nela não há o projeto de sempre estender os domínios, dominar, subjugar e destruir; há, sim, o projeto de rearticular e reinventar relações em um campo aberto e ilimitado no qual o direito internacional é negociado e contratual.

É provável que, estejamos vivendo, após o 11 de setembro, um novo período de reconfiguração de espaços e contradições internas do sistema do Império. A queda das torres gêmeas deflagrou uma guerra contra o terrorismo e, consequentemente, contra o mundo árabe. Mas só saberemos, com mais clareza e objetividade, acerca desse novo período, quando, num futuro próximo, as relações entre os interesses das nações do conflituoso mundo contemporâneo chegarem ao limite e uma nova ordem possa surgir.

Segundo Said (1994), os Estados Unidos sempre se opuseram a qualquer forma de nacionalismo ou de independência no mundo árabe, seja por razões relacionadas ao seu próprio imperialismo, seja por seu apoio a Israel, que, por mais de trinta anos, ocupa ilegalmente território palestino, violando as convenções de Genebra e conduzindo invasões e ataques terroristas aos Árabes. Um exemplo do apoio americano pode ser claramente observado por seu sempre veto a sanções a Israel em todas as votações nas Nações Unidas.

Said (1994) afirma que os únicos árabes com os quais os Estados Unidos estabelecem relações são aqueles que possuem lideres complacentes, homens de negócios ou militares, que ajudam a economia americana com a compra de armas. 
Entretanto, segundo o autor, Síria, Sudão, Líbia e Iraque são considerados Estados desonestos e trapaceiros. Além disso, há uma separação cultural entre esses oponentes, pois as tradições culturais e religiosas e as identidades árabes são consideradas inadmissíveis aos Estados Unidos, que veem os árabes como violentos e terroristas irracionais, sempre à espera de uma próxima oportunidade para bombardear algo e matar pessoas.

O conceito de Rogue State (Estado Desonesto), segundo Chomsky (1999), tem um papel fundamental na análise e no planejamento políticos. Esse tipo de Estado, visto como nação sem lei, dirigida por uma espécie de "reencarnação de Hitler", simboliza uma ameaça aos vizinhos, por isso deve ser contido pelos guardiões da ordem mundial: segundo Chomsky, Estados Unidos e Reino Unido.

Porque no mundo pós-Guerra Fria, não há mais sentido focar os interesses na União Soviética, os Estados Unidos, então, voltam sua atenção aos mais novos inimigos, os Rogue States, como, Iraque, Líbia, Cuba e Coréia do Norte. Na análise de Chomsky (1999), imediatamente após a simbólica queda do muro de Berlin, a administração Bush fez ao Congresso Nacional um grande pedido para orçamento do Pentágono, temendo que, com o fim da ameaça soviética, o terceiro mundo, e em especial o Oriente Médio, se transformasse na nova ameaça mundial.

Na avaliação de Said (1994), a moderna história americana é marcada pelo tema da contenção, segundo o qual os Estados Unidos exercem o papel de elite política mundial afim de evitar que rebanhos desgovernados no mundo sejam pisoteados. Por exemplo, um aumento expressivo do orçamento militar no governo Regan foi justificado sob a ideia de Império do Mal. Nesse momento a Líbia de Kadafi virou alvo de ataque americano afim de justificar esse aumento.

Chomsky (2005) assim descreve uma forma de derrubar um governo: armamse gradativamente os militares, dando-lhes poder e força para uma ação futura e, em seguida, provoca-se um caos econômico no país. E essa é uma estratégia que os Estados Unidos sabem articular muito bem, como se vê no embargo econômico a Cuba. Instalado o caos, o povo desgovernado pede por uma solução, e os militares, já armados e preparados, assumem o poder.

O comitê de segurança da ONU, baseado na Carta das Nações Unidas, afirma que o Conselho de Segurança deve determinar a existência de qualquer ameaça à paz ou de quaisquer atos de agressão e, quando constatado, deve recomendar ou decidir medidas a serem aplicadas. Qualquer país que se sinta ameaçado pode 
procurar o Conselho de Segurança e pedir autorização para responder à ameaça. Essas recomendações têm, segundo Chomsky (1999), pouca importância, se diante dos chamados Rogue States, que rejeitam essas leis.

Como mencionado anteriormente, valores Americanos não são valores universais. Segundo o autor (1999), para os Estados Unidos, agressão inclui subversão ou guerra política, a chamada "agressão interna". Um exemplo foi o bombardeamento de cidades líbias em 1986, cuja justificativa foi "autodefesa contra um futuro ataque". O mesmo aconteceu no Panamá, invadido em nome da prevenção do uso do território como base para a distribuição de drogas nos Estados Unidos.

Ainda sobre o conceito de "Rogue State" e a responsabilidade de proteger o mundo, Chomsky (1999) se questiona contra quem os Estados Unidos estão nos protegendo. O fato é há uma constante necessidade de inimigos que possam justificar as intervenções no mundo, algo similar à perpetua guerra na obra 1984, de George Orwell, que objetiva a unificação do povo contra um inimigo comum. No âmbito interno americano, afirma o autor (1999), o inimigo é o crime, especialmente as drogas, frequentemente associado a tensões raciais que colocam o país sob o risco de catástrofe social. No campo externo, o inimigo é o terrorismo internacional, como o narcotráfico hispânico e as ameaças advindas dos Rogue States.

Conforme Chomsky (2005), as intervenções dos Estados Unidos em outros países não estão relacionadas ao combate de uma ideologia de esquerda, mas sim à forma de impedir a independência. Se um país não quiser cumprir as funções designadas pelo sistema global norte americano, ele será combatido.

Segundo Said (1997), o Islã tem sido uma questão central na mídia e nas decisões políticas. Esse autor aponta que a maioria das discussões trazem à tona regimes amplamente apoiados pelos Estados Unidos. Esses regimes se mantiveram alienados de sua população, seguindo uma agenda americana, e não muçulmana. Os muçulmanos têm sido constantemente retratados como terroristas e fundamentalistas, porque uma repetida caracterização negativa, levantada principalmente por Israel, faz com que esse país seja visto como uma vítima da violência islâmica, visão essa que molda a forma como europeus e americanos veem Israel e os estados islâmicos. Conforme analisa Said (1978), um dos sentidos que o discurso engendra ao estabelecer uma comparação é o fortalecimento de uma das identidades envolvidas: "(...) a cultura europeia ganhou força e identidade comparando-se com o Oriente" (SAID, 1978/2001, p.15). 
Esse mesmo autor (1997) considera que, desde o final do século XVIII, tem havido uma simplificação radical do chamado Orientalismo. Há, de acordo com o autor, o "diferente" e o "nós", dividindo o mundo em duas partes, Oriente e Ocidente. Tomado como inferior, o Oriente sempre a parte desse mundo a qual tem um enorme poder destrutivo. E o Islã, pertencente a essa parte do mundo, é visto de forma monolítica, isto é, carregado de hostilidade e de medo e encarado como uma ameaça ao Ocidente e ao Cristianismo.

Said (1997) considera que muitos repórteres vão a países estrangeiros sem o mínimo preparo, sem nem mesmo conhecer o país ou a língua e, imediatamente, se apoiam em clichês e em "uma sabedoria jornalística" que os leitores provavelmente não questionam. Dessa forma, árabes e muçulmanos são considerados ora como fornecedores de petróleo, ora como terroristas potenciais, trazendo, essa visão, uma série de caricaturas que sustentam a ideia de um mundo vulnerável a agressões militares. $\mathrm{O}$ autor afirma ainda que as notícias mais dramáticas, normalmente de caráter negativo, incluindo o Irã, o conflito Israel e Palestina, Afeganistão e petróleo, são tidas como notícias sobre o Islã. Especialmente no caso do Irã, os modos mais comuns de retratar o islamismo são por meio do uso de uma hipérbole de agressão ou de um eufemismo aplicado erroneamente, todos derivados de uma escondida hostilidade ideológica. Said vai além, ao explicitar que qualquer tentativa de interpretar o mundo islâmico deve partir de circunstâncias à priori que disponibilizem a cultura como condição para essa interpretação. E as circunstâncias segundo as quais jornalistas, e mesmo acadêmicos, interpretam-no são regidas por interesses comerciais, coloniais ou militares.

A tese central de Said (1997) é a de que a mídia, o governo e a academia, quando da cobertura sobre o Islã, têm sido persuasivos e de forte influência. $O$ sucesso da cobertura sobre o Islã pode ser atribuído às pessoas e às instituições que a produzem, muito mais do que a verdade ou a acuidade dos fatos. O resultado, segundo o autor, é o triunfo de uma interpretação particular daquilo que vem a ser o Islã.

Said (2003) considera que a mídia tem muita influência no curso da guerra. A mídia torna-se o cenário de uma batalha por imagens e ideias. Israel é exemplo de um país que já investiu milhões de dólares na criação de imagens para o mundo exterior, financiando, por exemplo, jornalistas, viagens e universitários, além do financiamento de campanhas eleitorais. 
Israel busca a produção de certas imagens e o silenciamento de outras. Haveria, por exemplo, uma espécie de treino para que, constantemente, o Holocausto seja lembrado e para que se construa uma imagem negativa dos jornais árabes que atacam Israel. Esse país manipula, de forma muito eficaz, os Estados Unidos e o mundo, ao tornar os palestinos invisíveis por meio de uma prática de supressão da verdade. Procura-se incitar a ideia de que os ataques palestinos são puro ódio aos judeus, para com isso provar que esses são uma vítima inocente.

Para Chomsky (2005), há um complexo sistema de filtros nas instituições como a mídia os quais eliminam perspectivas dissidentes para deixar apenas a polaridade esquerda e direita. O que a mídia faz é formar um debate entre os pressupostos básicos existentes dentro do sistema, eliminando, pois, aquilo que estaria fora da "propaganda de estado". As críticas permanecem dentro dos limites aceitáveis e, portanto, são toleradas.

Um conceito emprestado de Walter Lippmann e utilizado por Chomsky (2005) pode ser seguramente usado pela mídia norte-americana: a fabricação da aquiescência. Não se tenta impedir o caos; antes, deixa-se que gradativamente ele se instale. A mídia contribui na fabricação do consenso de que a situação é impossível de ser tolerada, de que o estado perde seu poder de coerção, até que a multidão, um "rebanho desgovernado começa a se pisotear", e de que a elite política deve agir para evitar a catástrofe.

Na América, há um senso comum, conforme Said (2003), de que o país é mais um gigante adormecido do que um país em constante guerra com o mundo islâmico. O sentimento antiamericano é baseado em uma história concreta de mais de trinta anos de apoio israelense e opressão dos palestinos.

A retórica do poder da "Nova Ordem Mundial", promulgada pelo governo americano desde o final da Guerra Fria, produz a ilusão de benevolência e da distância do contexto imperial. Mas o panorama atual é bastante diferente. Europa e Estados Unidos, com sua população de imigrantes não brancos, encaram uma força de vozes que desejam que suas narrativas sejam ouvidas.

Said (1994) não acredita que os autores são mecanicamente dominados por ideologias ou por relações sócio-históricas. Eles são moldados e moldam a história e suas realidades sociais. Cultura e estética derivam de experiências históricas. Seleção e escolha consciente regulam as produções. 
Todas as culturas estão, de certa maneira, contidas em outras; nenhuma é pura ou singular. Todas são hibridas e heterogêneas. Mas, apesar de toda a diversidade, os Estados Unidos e outros países ainda se mantêm coerentes.

Segundo Hardt e Negri (2001), com a passagem para o império, as diferenças biológicas foram substituídas por significadores culturais: o comportamento dos homens não é resultado de seus genes ou sangue, mas sim derivado do fato de eles pertencerem a diferentes culturas historicamente determinadas. A cultura não é mais fixa e imutável, mas sim efeito contingente das histórias sociais. O racismo, por exemplo, opera por graus de desvio em relação à face do homem branco, estabelecendo, consequentemente uma estratégia de inclusão diferenciada, segundo a qual se colocam de lado as diferenças e tira-se o potencial das diversas subjetividades constituintes.

Os autores (2001) concluem que contingência, mobilidade e flexibilidade são o verdadeiro poder do Império. A solução imperial não é negar ou atenuar as diferenças, mas sim afirmá-las e ordená-las num efetivo aparelho de comando. Incorporar, diferenciar e administrar transforma-se no triplo imperativo do Império.

\subsection{A PRIMAVERA ÁRABE: uma perspectiva interna}

Com uma série de levantes populares, a Primavera Árabe tem início na Tunísia, espalha-se pelo Norte da África e, em seguida, pelo Oriente Médio. Segundo Brancoli (2014), o levante é constituído por países que compartilham certo grau de identidade árabe, seja pela língua, seja pela cultura, seja ainda pela história. Independentemente de um sistema de semelhanças, as diferenças existem e são de suma importância em cada um dos países.

A mídia normalmente retrata a Primavera como uma série de levantes que objetivam a liberdade e a democracia. Entretanto, o autor afirma que não se pode encarar a Primavera Árabe como uma revolução democrática. Em muitos locais, as revoltas têm como objetivo apenas a mudança de status quo, não garantindo que a vitória possa ser vista como libertária do povo contra um ditador maléfico, evitando uma visão que se baseia em estabelecer os bons e os maus. 
Tudo começa em Março de 2010, quando o ditador da Líbia, Muammar Gaddafi, ameaçava pela televisão os rebeldes de seu país. Em semanas, segundo Brancoli (2014), a situação chegou a um limite: Gaddafi fez ameaças aos rebeldes dizendo que "rios de sangue fluirão pelas ruas da cidade e que os insetos rebeldes seriam esmagados". Logo após esse pronunciamento, os Estados Unidos lideraram uma intervenção militar, a fim de "garantir" a vida dos ameaçados. Foi dessa maneira que a guerra civil se iniciou no país e deu origem à chamada Primavera Árabe.

O islamismo tem fundamental importância nas estruturas social dos países do conflito. Segundo Brancoli (2014), a religião islâmica pode ser observada como um conjunto de práticas e normas que ajudam a orientar o comportamento das pessoas, mas passível de variadas interpretações. Os dois maiores grupos são os sunitas, a maioria da população, e os xiitas. Além desses dois grupos, há outras divisões dentro do mundo árabe; por exemplo, na Síria, 11\% da população são alauítas do xiismo, sem contar a população expressiva de cristãos.

Brancoli (2014) entende haver um transbordamento de ações das revoltas de um país que acabam servindo de inspiração para outras. Entretanto, em todos os países, as lideranças árabes se mostram extremamente resistentes a pressões domésticas e internacionais, em que pesem o sistema político antiquado, os problemas econômicos e a incapacidade de eliminar os conflitos internos minoritários.

Por meio de um culto à imagem, os líderes conseguem colocar em seus países uma imagem de presença eterna no comando do país. Para lidar com as pressões do mundo moderno, as lideranças árabes foram capazes de implantar maior presença de uma imprensa livre e de organizações não governamentais, regulando e restringindo as atuações desses grupos. Em muitos lugares, podemos observar a criação de ONGs híbridas, fortemente vinculadas ao Estado.

Economicamente, na análise de Brancoli (2014), a maior parte dos países árabes tem suas economias dependentes de atividades não produtivas, tal como o petróleo. Nesses países, a relação entre o governo central e a população é fortemente ligada por benefícios financeiros, sendo muito comum, por exemplo, que, durante as revoltas, as lideranças tentem fornecer dinheiro diretamente à população, uma estratégia empregada para acalmar os ânimos. O Estado monta uma situação na qual o cidadão, por se ver beneficiado financeiramente, não questiona a administração.

Quanto à política externa dos Estados Unidos, o autor (2014) afirma que, após a Segunda Guerra Mundial, há uma aproximação americana na região. A Guerra Fria 
estabeleceu os objetivos americanos na área. Os regimes autoritários no mundo árabe eram vistos pelos americanos como mais preparados para o combate à ameaça comunista. Além da ameaça comunista, o petróleo também era de grande interesse americano. Ainda há, para o autor, um terceiro fator que se intensificou após o 11 de setembro: a ameaça do fundamentalismo islâmico. Tunísia, Egito e lêmen recebem dinheiro americano para o combate ao fundamentalismo em seus países.

Já de longa data percebe-se que sempre que uma alternativa aos governos autoritários pudesse ser a islâmica, os Estados Unidos prontamente apoiavam aos primeiros. O autor (2014) afirma que diversos ditadores se aproveitaram dessa situação e anexaram grupos rivais, classificando-os como perigosos para garantir o apoio financeiro americano.

Grande parte das revoltas no mundo árabe está relacionada às dificuldades econômicas, motivo pelo qual elas foram menos sentidas em nações árabes mais ricas. Os preços estavam constantemente aumentando e os Estados não conseguiam garantir oportunidades de emprego, principalmente aos jovens recém-formados. A população dos países mais pobres se via longe de qualquer benefício econômico, sendo incapaz, por meios políticos, de reverter, ou até mesmo debater em uma impressa livre, essa situação. Segundo Brancoli (2014), a desesperança e a falta de poder político geraram um amplo caminho para as revoltas.

Outro fator relevante nas revoltas da Primavera Árabe foi a mídia. As televisões locais, controladas pelo Estado, tinham uma programação dirigida de acordo com seus interesses. Entre 1990 e 1996, chegaram as televisões via satélite, possibilitando à população outro tipo de acesso à informação. Simultaneamente, a internet também chegou a essa população, não só possibilitando o questionamento de tradições e o acesso às redes sociais, mas também facilitando a troca de informações e a mobilização. Segundo o autor, muitos dizem que o germe das manifestações no Egito decorreu da criação, em 2008, de um evento no facebook que convocou a população para uma série de atos contra o governo, mas o autor alerta para o fato de talvez se esteja exagerando no papel das redes sociais nas revoltas no mundo árabe, já que a maioria dos usuários do facebook está localizada em países que não sofreram qualquer tipo de revolta. Um exemplo dado pelo autor é o caso do Egito, onde, durante as revoltas, apenas $5 \%$ da população tinha acesso ao facebook e $25 \%$, à internet. 
De acordo com Brancoli (2014), a tecnologia teve, sim, um papel relevante, mas os indivíduos foram os grandes promotores das mudanças, afinal foi o ato simbólico de um jovem tunisiano que, em protesto, imolou-se, que teria marcado as transformações e dado início a elas em todo o mundo árabe.

A seguir, examinamos brevemente as características da Primavera Árabe, caso a caso, e nos detemos em mais detalhes na Síria, nosso objeto de estudo, detalhando processos históricos do País os quais culminaram no presente momento.

\section{Tunísia e Egito: as sementes da primavera}

O início da Primavera Árabe na Tunísia, em setembro de 2010, deu-se em frente ao prédio da prefeitura, quando Mohamed Bouazizi imolou-se, dois dias após o sétimo confisco de sua banca de legumes e a humilhação e a desonra sofridas na tentativa de reaver seus bens. Esse ato expressava a desesperança e a frustração de todo um povo.

Apesar de a Tunísia, na visão de Brancoli (2014), ter sido colocada na lista das 30 nações mais competitivas do mundo, apenas $14 \%$ da população se percebiam participando desse crescimento. Questões como saúde, emprego para os jovens, burocracia estatal, corrupção, moradia e repressão política eram vistas com insatisfação pela população.

As insatisfações também estavam ligadas ao sistema político e à estrutura governamental. O presidente Ben Ali só teve concorrente nas eleições a partir de 1999, pois inúmeras regras barravam novos candidatos a cargos públicos.

As manifestações na Tunísia começaram no dia seguinte à imolação de Bouazizi. Apesar de diversas tentativas do presidente de negociar com os rebeldes, dos atos de repressão e da contenção das revoltas, Bem Ali perde o apoio de seus aliados e, no dia 14 de janeiro do ano seguinte, deixa o País para refugiar-se na Arábia Saudita. O primeiro ministro do país afirma, em pronunciamento, que Ben Ali estava temporariamente incapacitado de exercer as funções de seu trabalho. Esse fato marca a queda de um líder em um movimento popular, servindo, consequentemente como semente para outro país: o Egito.

De acordo com Brancoli (2014), a cidade do Cairo, por ser um centro urbano, cultural e intelectual do mundo árabe, teve o papel de catalizador daquilo que havia começado na Tunísia. De igual modo ao deste último País, os benefícios econômicos 
que atingiram o Egito, de 2000 a 2007 e posteriormente em 2010, não se estendiam a uma grande parte da população. As disparidades entre as classes sociais aumentavam cada vez mais. 20 \% da população estava abaixo do nível de pobreza e, como na Tunísia, muitos jovens com formação universitária estavam desempregados. A variação na economia e a alta da inflação atingiam boa parte da população, por isso o governo reagia doando mantimentos, principalmente pão (utilizado muitas vezes simbolicamente nas manifestações). A política também era uma fonte de insatisfação, pois o longo governo impedia a participação de partidos de oposição nas eleições e, mesmo que participassem, essas eram fraudadas, havendo, consequentemente, pouca representatividade da população.

O governo do Egito estava nas mãos do chamado grupo dos Oficiais Livres, que, por meio de golpe de estado, tirou a monarquia do poder. Esses oficiais eram vistos como libertários pertencentes às correntes imperialistas. Nasser, primeiro governante, consolida o poder do Egito na região ao se alinhar à antiga União Soviética. Já em 1970, Sadat chega ao poder, alinha-se com os Estados Unidos, de quem obtém um grande auxilio militar, e faz a abertura econômica para o capital estrangeiro. Após o assassinato de Sadat, em 1981, seu sucessor, Hosni Mubarak, cria uma força específica para lidar com os grupos de oposição, dentre os quais a Irmandade Muçulmana, cuja repressão desencadeia por anos consecutivos várias formas de protestos, principalmente em forma de greves e paralisações.

Segundo Brancoli (2014), a queda de Ben Ali, na Tunísia, prova que as manifestações populares poderiam trazer modificações na política. Sendo assim, a mobilização, por meio das redes sociais, começa a se intensificar no Egito. No dia 28 de janeiro, é marcada uma grande manifestação na praça Tahrir, onde, apesar da queda da rede de dados na cidade, reúne-se um grande número de manifestantes, então repreendidos pelas forças de segurança. Ao final do ato, os manifestantes conseguem expulsar as Forças de Segurança e ocupam a praça. Apesar de toda força, muitos incidentes se sucederam em toda a cidade, o que desqualificou os movimentos sob suspeita de infiltração de agentes do governo.

Apenas dezoito dias após o início dos protestos, Mubarak cai e então o Conselho Supremo das Forças Armadas assume o poder, prometendo eleição em seis meses. Mas isso não acontece. Os militares, apropriando-se de uma série de prerrogativas mantenedoras de seus sustentos e direitos, propõem regras confusas para as eleições e normas que justificariam os atos das forças armadas. Nessas 
eleições, o parlamento reconfigura incluindo a presença de islâmicos, que causando uma série de desconforto em grande parte do mundo. Dois dias antes do segundo turno, a Suprema Corte de Justiça dissolve o congresso recém-eleito, sob a alegação de incongruências nas votações, e o poder do executivo a ser eleito é, dessa forma, reduzido.

Mohamed Morsi, membro da Irmandade Muçulmana, é o primeiro presidente eleito do Egito. Morsi tenta, sem sucesso, reestabelecer o Parlamento e, mais tarde, demite a cúpula das forças armadas, anulando-lhes os limites dos poderes. Em novembro de 2012, surgem as primeiras manifestações contra Morsi dado o fato de a elaboração da constituição ser conduzida principalmente por islâmicos. A resposta de Morsi vem sob a forma de um decreto que lhe atribui plenos poderes. Evidentemente, as revoltas aumentam e acabam por forçar o presidente a reduzir novamente seus poderes. Em dezembro, em referendo popular, a constituição é aprovada.

Violentos protestos se sucedem nas semanas seguintes, até que, em 29 de julho, Morsi faz um discurso em tom conciliatório, mesmo assim, no dia seguinte, milhares de manifestantes tomam as ruas. No dia 3 de julho, as Forças Armadas suspendem a constituição e anunciam a formação de um novo governo interino. Um ano após o golpe, o General Adbul Fatah Khalil Al-Sisi é eleito o novo presidente do Egito.

\section{Bahrein: um lugar esquecido}

A Primavera Árabe atinge também a pequena ilha de Bahrein, um pedaço de terra muito pequeno no meio do Golfo Pérsico. As manifestações seguem, a exemplo dos outros dois países, movidas por insatisfações econômicas, falta de representatividade política e demanda por leis mais rígidas contra a discriminação. A maioria da população é xiita, e o País é governado por uma monarquia sunita, que está no poder desde o século XVIII.

O medo de uma guerra civil em Bahrein faz com que a Arábia Saudita reforce a segurança na região. O governo saudita não que um exemplo tão perto e, em poucas horas, esvazia a Praça Pérola, tomada pelos manifestantes dias antes.

\section{A Líbia de Gaddafi}


A história da Líbia está atrelada ao ditador Muammar Gaddafi, que chega ao poder em 1969 por meio de um golpe militar contra a antiga monarquia. De acordo com Brancoli (2014), desde a década de 70, Gaddafi se concentra em um panafricanismo e na união dos países do continente. Assim como todos os outros governos, Gaddafi mantém um forte esquema contra os oposicionistas: nacionalizou a maior parte das empresas, expulsou militares estrangeiros do país e mantinha uma política externa expansionista, financiando muitas guerrilhas em todo o mundo. Muitos ataques na Europa são atribuídos ao general, mas é após um atentado em Berlin também atribuído a Gaddafi, que matou dois militares americanos, que o então presidente americano Ronald Reagan ataca a Líbia pelo ar.

Após o final da Guerra Fria, o general se vê enfraquecido e começa a aproximar-se dos países da Europa e dos Estados Unidos, aproximação que beneficiou em muito a Líbia, levando-a a crescer numericamente números em todos os segmentos econômicos.

Segundo Brancoli (2014), entre conflitos pessoais com países da Europa e o início da queda daquele primeiro boom econômico, as políticas do governo não conseguem abarcar a população do país e a crise política se aproxima.

As revoltas na Líbia começam em cidades marginalizadas pela política central e, em seguida, espalham-se pela vizinhança. Muitos membros do governo, também descontentes, se juntam aos oposicionistas, e figuras importantes no governo do general abandonam o cargo. As ações do governo Gaddafi se assemelham ao genocídio em Ruanda em 1994, e suas palavras se aproximam das dos extremistas em Ruanda, os quais chamavam suas vítimas de insetos. Esse episódio é um exemplo da incapacidade de ação das Nações Unidas, que não conseguiram impedir o massacre de 1,5 milhão de pessoas no país africano. Isso faz o conselho da ONU afirmar que deveriam ser tomadas medidas para impedir a morte de civis na Líbia. Com isso, o espaço aéreo Líbio é fechado, e o CNT (Conselho Nacional de Transição) é reconhecido pela França como legitimo governo Líbio. Em março de 2011, as forças de coalizão começam a bombardear a Líbia. Sete meses após o início das intervenções militares na Líbia, em agosto, as forças rebeldes invadem Trípoli e o banker do ditador, que havia fugido alguns dias antes. Em outubro Gaddafi é assassinado pelos rebeldes.

Um curto espaço de calma se instala no país até que grupos extremistas atacam o consulado americano, matando o embaixador e três outros funcionários, fato 
que levantou dúvidas na comunidade internacional sobre a capacidade do governo em lidar com os grupos extremistas dentro da nação.

\subsection{A PRIMAVERA ÁRABE: o caso da Síria, uma primavera de mais de quatro estações}

Passamos agora para um histórico sobre o país-foco dos objetivos desse trabalho, buscando antecedentes históricos que forneçam um panorama até a Primavera Árabe.

Como aponta Brancoli (2014), as revoltas descritas anteriormente tiveram duas consequências possíveis: ou os ditadores foram derrubados, ou os revoltosos foram contidos. Em vários países, os acontecimentos se deram com relativa rapidez. Caso diferente é o da Síria, que ao que parece, a guerra está longe de ter um fim.

Há grande preocupação internacional com a Síria. Geograficamente, ela se encontra no coração do mundo árabe, fazendo fronteira com vários países, e os acontecimentos no território poderiam facilmente trazer consequências aos seus vizinhos.

Rubin (2013) afirma que a Síria é um caso exemplar de uma nova forma de poder no mundo Árabe. Quando ganhou a independência, a Síria se mostrava um país democrático, possuidor de terra fértil e de recurso naturais. Durante esse período, intensificou suas relações com o Ocidente e com uma classe média em ascensão. Apesar disso, a combinação de radicalismo intelectual, ideologias militantes e militarismo ambicioso levou o país a outro caminho. Segundo o autor, a Síria praticamente inventou o terrorismo subsidiado pelo Estado.

Nenhum outro país do Oriente Médio, segundo Rubin (2013), possui a multiplicidade étnica como a da Síria, em que todas competem pelo poder. A Síria de Bashar, apesar do pequeno tamanho e da modesta economia, se tornou um país com um papel fundamental no Oriente Médio. Uma das principais características da Síria é sua capacidade de criar problemas a serviço da manutenção de seu regime. Sendo um país pequeno, comparado à força do Egito ou ao dinheiro da Arábia Saudita, o regime sírio transcende slogans e valoriza o Arabismo e, mais recentemente, o Islamismo. O autor (2013) afirma que, em termos gerais, a Síria oferece o mais puro 
exemplo dos governos Árabes. Dois princípios básicos são norteadores desses governos. Um desses princípios se coloca avesso à visão Ocidental de que moderação, paz e economia aberta são os melhores caminhos, ao contrário segundo esse princípio de que o radicalismo é o melhor caminho para o governo, pois, causando problemas, escondem-se as fraquezas e justifica-se o controle interno rígido. O segundo princípio garante o sucesso do regime por fazer com que os sírios acreditem serem as lutas contra Israel e contra os Estados as prioridades nacionais.

Historicamente, afirma Rubin (2013), entre os anos de 1949 e 1970, a Síria era considerada o país mais instável do mundo. Questões de identidade eram eminentes, como: O que era a Síria? Onde era a Síria? O que era um sírio? Deveria a Síria se juntar ao Egito, à Jordânia, ao Iraque? Quem, nesse caso comandaria essa união? Que caminho a Síria deveria seguir: capitalismo ou socialismo?

Uma das maiores contribuições para o elenco de questões descritas era a complexidade dos grupos Étnicos Religiosos. Sessenta por cento da população eram árabes - muçulmana sunita; 13 por cento, cristãos; 12 por cento, alauítas; 9 por cento, curdos 5 por cento, drusos e alguns outros grupos minoritários, incluindo os judeus.

Rubin (2013) afirma que a Revolução Corretiva na Síria vem de uma ambição idealista, mas cujo principal objetivo era manter o regime no poder. Oficiais e políticos que subiram ao poder em 1963, em 1966 e finalmente em 1970 acreditavam que eles transformariam a Síria em uma nação moderna e uniriam o mundo árabe. A construção de um sistema que pudesse manter o regime não foi tarefa fácil para Hafez al-Assad e seus assistentes. Os lideres sírios usavam educadores, jornalistas, intelectuais e personalidades culturais para que a população pudesse obedecer a seus líderes e amá-los.

Além dos fatos anteriormente mencionados, há ainda o de que o regime estabelece um sistema de controle e de doutrinação. O partido está presente em todos os níveis da sociedade. Muito devido a razões econômicas, os membros do partido ficam cada vez maiores, chegando a $10 \%$ da população do país. Na maior parte das famílias, há pelo menos um membro do partido.

Hafez foi eleito cinco vezes presidente para um mandato de sete anos, permanecendo no poder vinte e nove anos no poder até a sua morte, em 2000. Todas as organizações sociais são comandadas por membros ou simpatizantes do Partido. Filiar-se ao partido significa maior ascensão na carreira. O autor (2013) aponta que 
os estudantes que se tornam membros do partido recebem pontos nas suas notas escolares, ficando mais fácil entrar em uma universidade de prestígio.

O partido Baath tem como slogan unidade, liberdade e socialismo. De acordo com Rubin (2013), unidade significa a união de todos os árabes; liberdade está relacionada à luta contra a dominação americana, israelense e ocidental; por último, socialismo, ao controle rígido do Estado e da centralização da economia.

É verdade que muitos sírios se beneficiaram do regime de Hafez, especialmente os mais pobres, pois grande parte da população é direta ou indiretamente funcionário do governo, o qual garantia sua sobrevivência. Tudo isso funcionava como um grande incentivo à lealdade ao partido.

Rubin (2013) aponta que o regime sírio é uma dinastia familiar, uma propriedade dos Assads. Eles têm origem na tribo Kalbiyya, próximo aos alauítas, para quem o regime trouxe um amplo desenvolvimento. Desde 1920, a França trouxe os alauítas ao seu exército, pois eles estavam alienados dos sunitas, que queriam a liberdade. Os alauítas se voltaram ao pan-arabismo, ou seja, ser árabe já é o suficiente, a crença religiosa não era mais fonte da identidade nacional. Hafez entende que os alauítas não poderiam governar sozinhos, por isso cultivou aliados sunitas. Assim, quando em 1970 a irmandade muçulmana se revoltou, os alauítas não receberam o apoio dos sunitas.

As forças militares sírias se expandiram de 50.000 homens, em 1967, para 500.000, em 1985. Mas, segundo o autor (2013), a Síria não se igualaria a Israel, pois faltavam armas e equipamentos, por isso a estratégia de Hafez foi a união com grupos terroristas, especialmente o Hezbollah.

Durante a segunda metade do século vinte, de acordo com Rubin (2013), a aliança síria com os soviéticos foi de extrema importância. Nos três primeiros anos de governo, Hafez visitou a União Soviética seis vezes. Em 1977, a Síria importou armas no valor de 825 milhões de dólares e, em 1978, o valor chegou a 1 bilhão. Além da compra de armas e equipamentos de guerra, muitos oficiais sírios foram treinados na União Soviética. Com o passar do tempo e o fim da guerra fria, os negócios foram diminuindo, e a Síria foi se tornando obsoleta nos equipamentos e nas armas.

Em 2005, a Rússia perdoou uma dívida Síria de 10 bilhões de dólares, mas Moscou estava novamente pronta para vender modernas armas para a Síria com pagamento imediato. Muito desse novo armamento foi parar nas mãos do Hezbollah e acabou sendo usado contra Israel, em 2006, na guerra do Líbano. 
O governo sírio sempre buscou, de acordo com Rubin (2013), não somente a repressão, mas também a manipulação. Um exemplo dessa manipulação pode ser observado em 2006, quando um grupo oposicionista se formou. Imediatamente, e aos moldes do governo totalitário e manipulador do livro 1984, de George Orwell, o governo deu a cada grupo algo desejado para acabar com o levante: aos curdos, foi oferecido o direto de usar a língua deles: aos intelectuais, a possibilidade de publicação de trabalhos e a autorização para viagens ao exterior.

A repressão pelo uso da força só acontecia quando o regime encarava um desafio real, como a morte de 83 cadetes alauítas em 1979, ou a tentativa de assassinato de Hafez em 1980 pela Irmandade Muçulmana. O mundo ocidental pouco intervinha nessas atitudes de repressão do governo, e isso garantia ainda mais o poder para o regime, que manipulava a população espalhando a ideia de que ninguém se importava com os cidadãos sírios e fazendo com que os dissidentes vissem poucas chances de gritar alto. Outra forma de repressão era silenciar as críticas fora do país por meio de assassinatos.

O autor (2013) afirma que a mídia também era totalmente controlada. Em 1963, os jornais independentes foram fechados, e os que permaneceram eram controlados pelo partido ou pelo governo. O mesmo se aplicava à rádio e à TV. Os assuntos divulgados eram sempre os mesmos: as ações governamentais de direitos humanos, a oposição ao Islamismo, as atividades das tropas sírias no Líbano e o material desfavorável à causa árabe-israelense. A internet e as transmissões via satélite eram mais difíceis de controlar, por isso o governo procurava criar uma imagem negativa delas, incluindo a TV al-Jazira, afirmando serem controladas por Israel.

Quando Bashar substitui seu pai Hafez, apesar da não religiosidade de seu líder, há um grande movimento islâmico: as escolas se tornam mais religiosas, mais mesquitas são construídas e várias ações aproximam o governo Bashar da religião. Internacionalmente, ele se torna um aliado do Irã islamita, patrono do Hezbollah e do Hamas e patrocinador dos islamistas sunitas no Iraque. De fato, Bashar cria uma nova corrente chamada de síntese nacionalista árabe-islamista. Islamistas e nacionalistas poderiam viver em harmonia se estabelecessem inimigos externos: a américa, o ocidente e Israel. 
Bashar estabelece uma ofensiva em três partes: encorajar o Islã não político no país, patrocinar grupos radicais islamistas em outros países e persuadir os sírios liberais de que os islamistas seriam os vitoriosos.

Mas a Síria sofre, conforme Rubin (2013), de um problema de homogeneidade relacionado à historia e à identidade, pois ela se coloca como centro do mundo árabe. Em vários contextos, a Síria obtém certo sucesso, principalmente no que diz respeito à manutenção do regime, bloqueando as pressões estrangeiras. Da mesma forma, consegue bloquear qualquer solução no conflito árabe-palestino, uma vez que suas ações de apelo árabe-nacionalista foi uma forma encontrada para subverter seus vizinhos. A questão palestina possibilitou que a Síria controlasse o Líbano, isolasse o Egito e impedisse que o Líbano fizesse as pazes com Israel. Após afastar do Egito os soviéticos em 1972, a Síria se torna o mais novo aliado soviético no Oriente Médio.

Com a queda da União Soviética, a Síria passa a fingir certa afinidade com os Estados Unidos, até encontrar um novo aliado: o Irã. Com Israel e Turquia, a Síria sempre evitou o confronto direto, usando, para esse fim, a estratégia de usar grupos terroristas revolucionários.

Quanto a suas relações com os Estados Unidos, sempre houve um clima hostil. De um lado, Egito, Israel, Jordânia, Turquia e Líbano eram aliados americanos e inimigos sírios; de outro lado, os aliados sírios eram a União Soviética, o Irã islamista e Iraque, todos os quais se oponham aos objetivos americanos.

Grupos terroristas eram mantidos e subsidiados pelo governo Sírio. Embora os Estados Unidos, em 1990, tenham dado ao governo sírio uma lista de grupos terroristas apoiados pelo governo sírio, a Síria continuou a fomentar esses grupos. Pouco fizeram os Estados Unidos a esse respeito. Nem mesmo após o 11 de setembro, a Síria foi alvo americano, mesmo tendo subsidiado o AL-Qaeda durante muito tempo, e não exatamente no ano de 2001.

Na visão de Brancoli (2014), a história da Síria sempre se mostrou repleta de conflitos. Após tornar-se independente da França em 1946, o País viveu um grande número de golpes e de tentativas de tomada do poder. Somente em 1963, com o golpe de Hafez al-Assad e a chegada do partido Baath, é que a instabilidade foi bastante reduzida.

Durante uma primeira fase, o governo tentou estabelecer um Estado laico em razão da variedade religiosa dentro do país. Isso resultou em uma grave crise no país: rebeldes acusavam o governo de distanciamento dos preceitos do islã e de 
aproximação dos soviéticos. Civis começaram a se aglomerar na capital e foram recebidos com bastante violência pelas forças do governo. Com a morte de Hafez alAssad em 2000, seu segundo filho, Bashar, assumiu o poder e deu sequência às políticas de seu pai, mas adotou novas práticas, como a liberdade política e de imprensa. Cedo, as novas medidas do governo mostraram seus limites.

Para Brancoli (2014), a abertura econômica, a diminuição de tarifas de importação e a criação de um forte programa de turismo foram reformas econômicas importantes. No entanto, essas transformações atingem apenas alguns poucos grupos sociais, especialmente os alauítas, ligados ao governo. Grande parte da população ainda se vê privada dessas mudanças, pagando mais caro por sua sobrevivência.

Mesmo após a queda do ditador egípcio, a onda de protestos não havia alcançado a Síria. Foi somente um mês depois, em Deraa, quando algumas crianças foram presas, espancadas e torturadas por picharem num muro palavras de ordem contra o regime, que se iniciaram os conflitos. Muitos moradores saíram em protesto foram para as ruas, mas foram reprendidos pelas forças do governo. Foram se sucedendo vários eventos, que eram, de forma desencontrada, narrados pelos dois lados. Bashar afirmava que os conflitos eram incentivados por organizações de fora do país, por isso os rebeldes eram violentamente reprendidos pelo governo com sequestros e assassinatos. Entre os rebeldes havia crianças, que eram mortas e cujos corpos eram enviados às famílias como forma de aviso. Em 2012, o número de mortos passava de 50 mil.

Apesar da guerra civil, a Síria demorou a sofrer uma interferência externa. Segundo Brancoli (2014), a questão da não interferência na Síria diz respeito às ações acontecidas na Líbia que resultaram na queda de Gaddafi. Rússia e China afirmavam que os movimentos na Líbia foram motivados pela inimizade do governo do país contra os Estados Unidos. O conselho internacional queria novos parâmetros para as intervenções internacionais. Os vetos russo e chinês no conselho de segurança da ONU podem também ser associados aos interesses econômicos e militares dos países na Síria.

A Rússia continuava mandando armamento ao governo sírio, visando, por exemplo, a manutenção da instalação naval de Tartus, um importante ponto estratégico russo fora de seu território. Assim como a Rússia, o Irã também enviou tropas ao País. Por outro lado, países ocidentais, como Quatar e Arábia Saudita, 
enviavam armamento para os rebeldes. A configuração social da Síria, composta por várias minorias em constante tensão, também foi vista como um dos motivos de uma não ação internacional.

De acordo com Brancoli (2014), o uso de armas químicas pelo governo de Assad foi um ponto bastante delicado nesse conflito. Em maio de 2013, uma comissão da ONU afirmou que tanto Assad quanto os rebeldes teriam usado armas químicas. Os bloqueios e sanções ocidentais pouco efeito tiveram na Síria, pois muitos governos têm a capacidade de levantar fundos em outros lugares, seja por meio de ações ilícitas, seja por meio do suporte de países aliados, no caso da Síria, o suporte do Irã.

Brancoli (2014) afirma que a Primavera Árabe não pode ser vista como um resultado, mas sim como um processo que ainda pode chegar a outras monarquias no Golfo. Todos os países da região, afetados ou não pelas revoltas, tiveram de se adequar às repercussões da Primavera.

Um segundo ponto levantado pelo autor é o duplo papel dos poderes ocidentais. Nas revoltas do Egito e da Tunísia, os Estados Unidos se apoiaram dos rebeldes; na revolta de Bahrein, isentaram-se completamente. A França, até dias antes da queda de Ben Ali, oferecia armas para o governo conter os rebeldes; já no caso da Líbia, a França mudou radicalmente seu discurso, deslocando-o da proximidade com o ditador Gaddafi para a coordenação da intervenção no país. Segundo o autor, talvez o grande benefício da Primavera Árabe seja uma capacidade regional de construir seu próprio futuro.

Gostaríamos de observar que as teorias apresentadas nesse capítulo, apesar de claramente motivadas por visões ideológicas muitas vezes antagônicas, são relevantes para o desenvolvimento dessa pesquisa, pois definem as condições de produção do discurso a ser analisado, oferecendo uma base histórica e analítica para que nossa interpretação possa ser feita. 


\section{CAPÍTULO 4: DO FUNCIONAMENTO DISCURSIVO NA COBERTURA DA GUERRA NA SÍRIA PELO JORNAL THE NEW YORK TIMES}

Os filósofos elaboram leis imaginárias para comunidades imaginárias, e seus discursos são como estrelas que dão pouca luz por estarem muito altas (BACON, apud CARR, 1946)

Este capítulo tem como objetivo analisar regularidades discursivas que permitam observar a estrutura e o funcionamento do discurso na cobertura da guerra da Síria feita pelo jornal The New York Times. Essa cobertura foi realizada no período inicial do conflito e a partir de uma visão discursiva apresentada na introdução deste trabalho.

Dividimos o capítulo em duas partes: na primeira, analisamos, baseados em nosso corpus, quatro categorias distintas e interligadas, essenciais para a compreensão do discurso delimitado. Iniciamos, investigando a construção discursiva do objeto, a saber, da guerra e do inimigo. Em seguida, focamos o sujeito que fala: quem é esse sujeito que tem o direito de dizer, como esse direito é construído e quais são as circunstâncias e os rituais dessa sociedade do discurso, sempre atentos a identificar quais discursos antigos alimentam e fundamentam o atual discurso sobre a guerra da Síria. Simultaneamente, construímos um quadro que nos permite observar quais são as apropriações, exclusões e limitações desse discurso em um sistema de coerção, constituinte de um saber sobre a guerra que garante a construção de uma episteme legitimadora da verdade sobre a guerra. Na segunda parte, concentramos nossa análise no discurso político interno norte-americano, discutindo as polêmicas e as contradições típicas de discursos decorrentes de posições políticas antagônicas. 


\section{1 - A construção do objeto: a guerra}

Inicialmente identificamos na análise de nosso corpus a construção de dois objetos distintos: a guerra e o inimigo. Tomando como ponto de partida a ideia de que o objeto é delimitado, percebido e representado a partir de um conjunto de discursos que o constituem como objeto, Foucault, em As Palavras e as Coisas (1966), afirma que práticas discursivas dão origem a uma episteme, ou seja, a um conjunto de relações estabelecidas em um dado momento histórico para constituir uma verdade, um saber que circula na sociedade.

Qualquer percepção do mundo evocaria um conjunto de discursos capaz de nos fazer perceber o mundo de uma forma, e não de outra. Constituidoras do próprio objeto, as palavras advêm de um conjunto de outros discursos, situados nas mais diversas formações discursivas.

Dessa forma, uma série de acontecimentos discursivos narrados pelo jornal constrói a noção de guerra e caracteriza a figura inimiga, por isso identificamos em nosso corpus algumas formações discursivas que, invocadas, delineiam o objeto.

Iniciamos, apontando que guerra está relacionada às noções de confronto, luta, batalha as quais se configuram a partir da existência de um conflito. $E$ uma das formas de se entender esse conflito é associá-lo com a violação de uma lei ou de uma norma social. Todorov (1970), em sua pesquisa sobre a narrativa literária, considera que a unidade de qualquer narrativa, virtual ou real, é a intriga. A partir desse princípio, o autor (1970) define o caráter mínimo da intriga que passa pela violação da lei.

A narração da guerra pelo jornal The New York Times, embora não-literária, sugere que há um confronto, uma luta em desenvolvimento na Síria, consequentemente assumimos que há o estabelecimento do conflito e da intriga.

Sendo característica da intriga a violação da lei, buscamos entender em nosso corpus qual lei foi violada na guerra da Síria, para o que recorremos a um documento normativo de caráter supranacional, a Declaração Universal dos Direitos Humanos.

Nessa Declaração (1948), especificamente no artigo III, encontramos a afirmação de que "Toda pessoa tem direito à vida, à liberdade e à segurança pessoal." e, no artigo XX, a afirmação de que "Toda pessoa tem direito à liberdade de reunião e associações pacíficas." Com raízes na história de países como Estados Unidos, 
Inglaterra e França, a Declaração Universal dos Direitos Humanos atua como uma espécie de constitucionalismo internacional legitimado pelas poderosas nações mundiais. Exploramos, com maior profundidade, esse "constitucionalismo imperial" em nosso próximo capítulo. Para o momento, somente utilizaremos a Declaração como base jurídica para justificar o estado de guerra que se impôs.

Afim de acompanhar a construção discursiva do estado de guerra, usamos alguns excertos do jornal The New York Times de 2011, ano do início dos conflitos na Síria.

4.1

\section{Syrian Troops Open Fire on Protesters in Several Cities}

Published: March 25, 2011

CAIRO - Military troops opened fire during protests in the southern part of Syria on Friday and killed peaceful demonstrators, according to witnesses and news reports, hurtling the strategically important nation along the same trajectory that has altered the landscape of power across the Arab world.

4.2

In Syria, Tension and Grief After Protests and Government Retaliation

Published: March 27, 2011

CAIRO -- Violence continued to plague Syria on Saturday, as government forces killed more demonstrators in Latakia, protesters burned offices of the ruling party in the south and west, and mourners throughout the country buried the dozens of unarmed protesters killed a day earlier.

President Bashar al-Assad of the ruling Baath Party began the day in what appeared to be a gesture intended to ease the crisis, when he announced the release of as many as 200 political prisoners. But by sunset, Baath Party offices were burning in at least two cities, the military was deployed in Latakia and once again government forces opened fire with live rounds, witnesses said.

4.3

\section{Syria Escalates Crackdown as Tanks Go to Restive City}

Published: April 25, 2011

BEIRUT, Lebanon - The Syrian Army stormed the restive city of Dara'a with tanks and soldiers and helped detain dozens in towns across the country Monday in an escalation of the crackdown on Syria's five-week-old uprising, according to residents and human rights 
No primeiro excerto (4.1), observamos a descrição da ação das tropas militares comandadas pelo governo sírio, abrindo fogo e matando civis em um protesto no Sul da Síria. O protesto é claramente descrito como pacífico, e a repreensão feita pelo governo coloca a nação no mesmo caminho trilhado por seus vizinhos: uma série de movimentos vindos de novas organizações políticas e sociais como a Primavera Árabe, discutida anteriormente. Além da ação, o texto também comenta a disposição do Estado em usar forças letais. Sem dúvida, o incidente narrado se coloca contra os dois artigos da Declaração Universal dos Direitos Humanos já citados. Há a violação do direito de reunião e associação pacífica, assim como do direito à vida, à liberdade e à segurança pessoal.

Dois dias depois, o segundo trecho (4.2) aponta a onda de violência na Síria e as forças do governo Sírio matando os manifestantes e retaliando as manifestações. A presença de grupos dos direitos humanos, em ambos os artigos, confirma as informações e dá credibilidade a elas, além de funcionar como uma espécie de evocação discursiva para o texto da Declaração dos Direitos Humanos. Mais uma vez, o segundo artigo enaltece a violação do direito à vida, avaliada por instituições que visam garantir esse direito.

Um mês depois, o terceiro artigo (4.3) assegura que o panorama construído pelos artigos anteriores se mantém, levando-nos a perceber que o que era localizado se espalha por várias cidades do país. A cena ganha caráter de terror quando a descrição incorpora a imagem de corpos jogados na rua. Assim, observamos na progressão da narrativa a reincidência das ações do governo sírio, reafirmando repetidas vezes, e de forma cada vez mais enfática, a violação das leis acima citadas.

O embrião da imagem da guerra já está construído pelo jornal, que claramente coloca os fatos como a quebra de uma ordem e de um direito. Mas a palavra guerra ainda não é, de fato, mencionada textualmente no que se refere ao caso da Síria. Em algumas reportagens, encontramos a palavra "war" referindo-se a série de levantes acontecidos em todos os países integrantes da chamada Primavera Árabe. Vejamos como e quando a palavra guerra é textualmente materializada no caso específico da Síria.

Em uma reportagem de 26 de março de 2011, a situação na Síria é descrita como um conflito (clashes) ou como o caos (chaos) sem que ainda se configure verbalmente uma guerra, como vemos no excerto abaixo: 
4.4

Even as the Obama administration defends the NATO-led air war in Libya, the latest violent clashes in Syria and Jordan are raising new alarm among senior officials who view those countries, in the heartland of the Arab world, as far more vital to American interests. (...)

Deepening chaos in Syria, in particular, could dash any remaining hopes for a Middle East peace agreement, several analysts said.

Em nossa pesquisa, a primeira ocorrência da palavra guerra (war), diretamente ligada ao conflito na Síria, aparece em 12 de fevereiro de 2012, no segmento "It is increasingly clear that Syria's sectarian war is becoming the regional conflict that analysts have long feared.", de um artigo que classifica a guerra como regional e sectária dentro da própria Síria e em suas relações com outros países e grupos do mundo Árabe. A guerra parece ser reduzida a um conflito interno, preocupante para o resto do mundo, mas sem correlações maiores com o Ocidente.

A segunda ocorrência aparece primeiramente como o relato das palavras e, em seguida, como a citação de um pronunciamento da então secretária de defesa norte-americana, Hillary Clinton. Em seu pronunciamento, ela ataca a Rússia por sua demora de agir na violência no país contra o presidente Bashar al-Assad e por impedir que as Nações Unidas consigam aplicar sanções mais fortes. A secretária inclusive acusa a Rússia de continuar suprindo armas para o governo de Bashar. Em dois momentos, o texto define a guerra como uma "guerra civil" (Civil War).

4.5

Secretary of State Hillary Rodham Clinton signaled the Obama administration's
mounting frustration with Russia over the unending violence in Syria on Thursday, saying that
Russia's refusal to take decisive action against President Bashar al-Assad threatened to
precipitate the very civil war that Russian diplomats have said they wanted to avoid.
$(\ldots)$
"The Russians keep telling us they want to do everything they can to avoid a civil war,
because they believe that the violence would be catastrophic," she said.

No mesmo artigo, ainda há uma citação do secretário geral das Nações Unidas também classificando os conflitos como guerra civil: 

Nations, said that the killings in Houla "could plunge Syria into catastrophic civil war - a civil war from which the country would never recover."

O que devemos resgatar da memória discursiva é a guerra civil mais famosa da história. Quando evocamos, especialmente em território americano, a expressão guerra civil, imediatamente nos lembramos da guerra de secessão de 1861. Dessa forma, enntramos em contato com uma memória discursiva de um país dividido entre Norte e Sul, os quais - depois de quatro anos de luta - são novamente unificados, tendo como valores vitoriosos a liberdade, o progresso e o desenvolvimento. Ao evocar a guerra civil, evocam-se também esses valores vitoriosos, deslocando-os de 1865 para a cena do conflito presente. É como se alinhássemos um dos lados da guerra aos valores descritos e defendidos, os quais, no caso da Síria, seriam representados pelos rebeldes, já que o artigo e as palavras da secretaria de defesa americana se colocam claramente contra o governo de Bashar; já aos russos e ao presidente Bashar, restam os papéis dos Confederados.

Enquanto um conflito armado entre governo e rebeldes acontece nas ruas das cidades sírias, outro parece acontecer dentro das Nações Unidas entre os estados aliados, representados pelos Estados Unidos, e aqueles representados por russos e chineses que ainda apoiam o governo de Bashar.

A primeira vez que a palavra "civil" deixa de ser mencionada é em 29 de julho de 2012, numa manchete do jornal: "As Syrian War Drags On, Jihadists Take Bigger Role". A partir dessa data, e em nosso corpus, rara é a aparição da palavra "civil" no período inicial da guerra da Síria, embora a Cruz Vermelha tenha declarado, em julho de 2012, a guerra como "Guerra Civil", ou mais precisamente, "conflito armado não internacional". Percebemos, entretanto, que a palavra retorna em um momento posterior, o qual se coloca fora dos objetivos desse trabalho, por considerarmos metodologicamente apenas o primeiro momento.

Um fato que nos desperta atenção é que a exclusão dessa palavra coincide com a retirada, do País, dos observadores das Nações Unidas, como relata o texto do dia 16 de agosto de 2012: apenas um pequeno número de oficiais ficou lá na esperança de uma solução pacífica. 
4.7

The United Nations Security Council decided on Thursday to terminate the United Nations observer mission in Syria, where the increasingly violent rebellion against President Bashar al-Assad's government has left diplomatic peacemaking efforts paralyzed. But the Security Council agreed to keep a much smaller United Nations office in the country, holding out hope that a political solution was still possible.

4.8

Still, the Security Council's decision runs the risk of further marginalizing the role of the United Nations in the Syrian war, leaving it vulnerable to the same criticism of inaction that it has faced in other major armed conflicts where civilians have suffered massacres and other brutalities.

Uma guerra civil tem como característica sua endogenia, ou seja, um conflito vindo do interior e, nesse caso, o papel da ONU poderia ser de mediador do conflito. Quando a guerra não é classificada de civil, ela ganha um caráter exógeno, ou seja, externo ao território. A retirada dos observadores das Nações Unidas pode indicar que o conflito ganha caráter exógeno, caso em a Síria sairia então de uma guerra interna, e a porta de entrada da intervenção global ficaria aberta. $O$ excerto 4.8 acima pode muito bem representar esse segundo discurso; com o afastamento das Nações Unidas, o País ficaria vulnerável, e a organização perderia consequentemente seu papel de proteção da população civil. $O$ texto inclusive constrói uma crítica a essa ação chamando-a de inação, o que levou anteriormente a vários massacres de civis. Desta forma, o discurso constrói a legitimação da participação dos organismos internacionais para deter a morte de inocentes.

A seguir, examinamos qual abertura simbólica/discursiva se dá com a saída parcial das Nações Unidas do território. Para isso, dividimos o corpus em dois momentos: o primeiro refere-se à posição americana no primeiro momento, quando a guerra era chamada de conflito ou guerra civil; o segundo, ao período em que o conflito já era chamado de guerra síria.

Observemos alguns sentidos produzidos no primeiro momento:

4.9

TUNIS - Representatives of more than 60 nations and organizations called on Syria's government on Friday to halt its attacks on besieged cities and asked the United Nations to 
begin planning for a peacekeeping force, even as prospects for a diplomatic way out of the conflict appeared dim. (24/02/2012)

Esse fragmento, de uma reportagem publicada em 24 de fevereiro de 2012, refere-se tanto à cobertura de um encontro, na Tunísia, de representantes, de mais de 60 países e organizações quanto a suas deliberações, dentre as quais um pedido formal para que os ataques na Síria parassem e para que as Nações Unidas preparassem uma força para a manutenção da paz. O texto também aponta que a solução diplomática parece ter uma chance muito pequena. Vale frisar que, apesar de haver 60 representantes nesse encontro, a reportagem é acompanhada de uma foto apenas da então secretária de estado norte-americana, Hillary Clinton, chegando à Tunísia. No parágrafo seguinte dessa mesma reportagem, transcrito parcialmente abaixo, apontam-se as ações acordadas por essas nações e organizações para o chamado conflito. Essas ações, transcritas da própria da reportagem, são:

\footnotetext{
- the delegates here vowed to tighten sanctions on Syria, though they have had little effect so far

- $\quad$ issued a call for a cease-fire to allow aid deliveries.

- They pledged to provide millions of dollars' worth of food and medicine to be distributed to Syrians from Turkey and Jordan.

- The final statement here dropped a call by some nations for "a peaceful, nonmilitary solution" in favor of wording sought by the United States and others who wanted a more open-ended reference to "a political solution" that did not preclude military action, but did not endorse it either.
}

Para o assim chamado conflito, a reportagem elenca duas promessas vowed e pledged -, uma exigência - issued a call - e uma afirmação ambígua dropped a call - com relação a uma intervenção militar - not preclude .... but not endorse.

As duas promessas são atos comissivos por meio dos quais os representantes atribuem a si responsabilidades, mas a exigência é um ato diretivo que atribui ao outro o dever da ação. Essas responsabilidades e a exigência são de caráter humanitário, pois visam atender a população síria. Esse duplo ato presente na última 
afirmação tem mais um caráter de ameaça, deixando implícita a possibilidade de uma intervenção militar, caso a demanda não seja atendida.

O comitê de representantes age aqui como uma instituição supranacional regulativa, assumindo posição deliberativa, inclusive com direito a aplicar sanções de caráter evidentemente humanístico.

Tanto por conta da imagem da secretária de defesa norte-americana quanto pelo teor humanitário das ações, o espírito humanitário norte-americano se mostra discursivamente presente. Em solo americano, são extremamente comuns os programas de ajuda aos afetados por algum desastre, ou catástrofe. A população norte-americana se reúne em associações voluntárias para dar assistência imediata às vítimas das tragédias, padrão que parece ser o mesmo aqui. Pertencentes a esse universo discursivo, palavras como doações, ajuda (aid) medicamentos, comida pertencem a esse universo discursivo têm seus sentidos então deslocados para o conflito, gerando uma imagem discursiva de igual teor que vitimiza o outro e coloca o enunciador em posição de benfeitor.

Sem dúvida essa imagem está atrelada ao povo americano, na figura de Hillary Clinton, que, simbolicamente, representa esse benfeitor dos necessitados. Nesse sentido, três posições são discursivamente criadas: a vitima, o benfeitor e o algoz (aquele que deve satisfazer as exigências, qual seja, o governo sírio).

Para compararmos o primeiro momento - em que a palavra guerra aparece junto ao adjetivo civil - com o segundo momento, em que a palavra guerra perde a denominação "Civil" e se transformar em apenas guerra, analisamos excertos do segundo momento. A reportagem escolhida foi publicada em 20/08/2012 e reporta à primeira ameaça direta, feita pelo presidente Barack Obama:

\section{Obama Threatens Force Against Syria}

WASHINGTON - President Obama warned Syria on Monday that it would face American military intervention if there were signs that its arsenal of unconventional weapons was being moved or prepared for use. It was Mr. Obama's first direct threat of force against Syria, as he has resisted being drawn into the bloody 18 -month rebellion.

4.11

The warning brings Mr. Obama, who has brushed aside calls to impose a no-fly zone or to arm the Syrian rebels, a step closer to direct American engagement. 
4.12

"We cannot have a situation in which chemical or biological weapons are falling into the hands of the wrong people," Mr. Obama said in response to questions at an impromptu news conference at the White House. "We have been very clear to the Assad regime but also to other players on the ground that a red line for us is, we start seeing a whole bunch of weapons moving around or being utilized."

"That would change my calculus," he added. "That would change my equation."

4.13

The Pentagon contingency plans include worst-case scenarios that would require tens of thousands of American troops, two senior United States officials said on Monday. The officials, who declined to specify precisely how many troops might be needed, emphasized that the plans were the kind of worst-case contingency options that the Pentagon routinely draws up in crises, and that no American deployments were imminent.

Em primeiro lugar, vale a pena destacar a expressão "American military intervention" no excerto 4.10. Os Estados Unidos têm histórico bastante longo de ações militares em países estrangeiros, ocupando o primeiro lugar em número de intervenções. Desde antes da primeira guerra mundial, em 1898, as intervenções militares americanas separaram as Filipinas, Cuba e Porto Rico da Espanha. Em todos esses casos, os motivos declarados, desde as primeiras intervenções, são exatamente os mesmos: defender os direitos das populações de civis, sempre em nome da liberdade e da democracia, conceitos fundamentalmente americanos e difundidos por todo o mundo. Na verdade, há a defesa de um princípio ideológico muito arraigado na sociedade americana, conforme se constata com precisão na fala do Presidente Barack Obama: "We cannot have a situation in which chemical or biological weapons are falling into the hands of the wrong people,"

$\mathrm{O}$ artigo enfatiza a recusa do Presidente em participar mais ativamente do conflito, como podemos ver em:

4.14

It was Mr. Obama's first direct threat of force against Syria, as he has resisted being drawn into the bloody 18-month rebellion. 
O enunciado em questão parece colocar-se contra a posição de Obama de ser resistente à rebelião sangrenta, como se, apesar sangrenta, o presidente se mantivesse distante. Por fim, o restante do texto endossa a ação do americano, comentando e, em seguida, citando textualmente suas palavras em resposta à afirmação anteriormente descrita.

4.15

The warning brings Mr. Obama, who has brushed aside calls to impose a no-fly zone or to arm the Syrian rebels, a step closer to direct American engagement.

"That would change my calculus," he added. "That would change my equation."

Nesse momento é como se o país devesse cumprir seu "Destino Manifesto" e o presidente Barack Obama fosse seu porta-voz: uma espécie de ícone que clama por intervenção militar que garantiria a liberdade, a democracia e a proteção dos civis.

$\mathrm{Na}$ passagem de um texto para o outro, podemos destacar algumas semelhanças e algumas mudanças. Evidentemente, permanece o caráter humanitário do discurso americano, que, no momento anterior, se dá pela legislatura e, no momento posterior, pela ameaça do uso da força, diferindo apenas pelo fato de que uma voz individual surge com mais força. Anteriormente, os Estados Unidos estavam diluídos em meio a uma espécie de comitê, ou de conselho, ou ainda de representação internacional, mas, no momento posterior, a nação americana aparece singularizada, mais ideológica e definida.

Com isso podemos responder à questão anteriormente feita sobre que abertura se dá com a saída das Nações Unidas da Síria. Discursivamente, podemos afirmar que a guerra, ao deixar de ser um conflito civil, ganha status de Guerra: a individualidade ideológica nacional americana ganha força e traz à superfície o histórico de intervenções internacionais o qual aciona seus princípios ideológicos de Destino Manifesto Americano que luta pela liberdade e democracia, procurando, dessa forma, se "multiplicar aos milhões". 
Hardt e Negri (2001, p.15) admitem que o Império alcança toda a ordem social:

O Império não só administra um território com sua população, mas também cria o próprio mundo que ele habita. (...) O objeto de seu governo é a vida social como um todo, e, assim, o Império se apresenta como forma paradigmática de biopoder.

Buscando um dar conta de um dos objetivos de nossa análise, podemos dizer que a construção da guerra como objeto discursivo cria dois objetos distintos, isto é, dois tipos de guerra, mas com muitas similaridades. O primeiro é a chamada guerra civil, que mantém ainda seu caráter endógeno devido aos discursos exteriores ainda difusos entre agentes e ideologias. O segundo objeto surge, a partir da retirada dos observadores internacionais da Síria em meados de agosto de 2012, quando guerra deixa de ser chamada de civil por adquirir caráter exógeno, constituindo assim um segundo discurso, mais personificado e ideológico.

Esse discurso se alinha a processos ideológicos profundamente arraigados nos Estados Unidos. Os dizeres oficiais do presidente americano, ou de seus ministros e assessores, são constituídos de uma memória discursiva que remonta a própria origem da nação.

Foucault (1971), vendo o discurso na ordem das coisas e das leis, afirma que não há como tomar a palavra sem estar envolvido por ele, isto é, por um passado de ditos e reditos. É que a produção discursiva, na acepção de Foucault, é controlada, selecionada e organizada, razão por que estamos constantemente redistribuindo discursos para que poderes, ainda na esteira de Foucault, possam permanecer ou transformar-se em outros.

A própria mídia, exatamente por seu pertencimento nacional, também está constituída desses mesmos valores, vistos, por exemplo, sob a forma de crítica à postura pacifista do presidente Obama. Nesse aspecto, cabe antecipar que encontramos, em nosso corpus, várias reportagens que entatizam o aspecto desumano da guerra, clamando, muitas vezes, pela proteção dos civis, da liberdade e da democracia. Comentamos, oportunamente, esses textos. 


\section{1: A construção do objeto: o inimigo}

Seguimos com a análise da segunda divisão proposta, a da "construção do objeto", concentrando-nos agora na figura do inimigo.

Mencionado em capítulo prévio, Chomsky (1999) admite que, mesmo com o fim da Guerra Fria, os Estados Unidos se colocam na responsabilidade de proteger o mundo, mas o autor se questiona sobre contra quem o país deve proteger. Lembramos que a fabricação de inimigos justifica as intervenções no mundo e unifica o povo contra um povo hostil.

Iniciamos nossas considerações com uma das primeiras reportagens sobre o conflito na Síria pelo jornal The New York Times, publicada em 18/03/2011

\subsection{6}

Protests broke out in four Syrian cities on Friday, the first large-scale demonstrations here since the pro-democracy uprisings began in the Arab world three months ago. Brutal police crackdowns followed, leaving six people dead and scores injured.

Duas ocorrências no excerto acima chamam a atenção. A primeira é o termo "pro-democracy", que não se refere apenas à Síria, mas também à série de manifestações da Primavera Árabe. Se entendermos que as demonstrações na Síria são pró-democráticas, pelo menos na visão da reportagem, então o Estado atual é não democrático, pois ninguém faz manifestação por algo já existente.

A dúvida que aqui é lançada é qual o conceito ideológico de democracia que se tem como referência. Seria, na visão dos manifestantes sírios, o movimento compreendido como pró-democrático nos mesmos termos? Ou seria apenas a visão de um sujeito que já internalizou o conceito ideológico de democracia, formado pelos padrões ideológicos americanos?

O segundo termo usado que também chama a atenção é "crackdowns". $\mathrm{Na}$ definição dicionarizada, a palavra crackdown refere-se a medidas aplicadas que tentam restringir ações ou pessoas indesejadas ou ilegais. Novamente, nos questionamos sobre a base legal da reportagem para que a ação da polícia síria possa ser classificada como ato de restrição a algo que não é desejado ou ilegal. Em outras 
palavras, a reportagem já classifica a manifestação de ilegal aos olhos da polícia e consequentemente aos olhos daqueles que a controlam, ou seja, o governo sírio. Considerado, pode-se resumir que o artigo do jornal atribui ao governo sírio um olhar repressor a qualquer tentativa de instauração de um governo democrático, e assim, atribui um valor oposto, ou seja, ditatorial.

O primeiro olhar ao objeto discursivo da figura do inimigo já o classifica como contrário às ideologias democráticas de cunho americano e atribui-lhe um valor negativo, ditatorial. Outro trecho da mesma reportagem confirma nossa análise:

4.17

Antigovernment protests are virtually unknown in Syria, a police state where political opposition has been brutally suppressed in the past.

Esse trecho deixa bastante claro o caráter ditatorial do governo sírio ao coibir brutalmente qualquer forma de protesto anti-governo. Uma primeira característica do inimigo contra o cidadão civil sírio já está construída pelo relato da reportagem. Então, buscamos algumas outras características da construção discursiva do inimigo, para o que, analisamos três trechos de uma reportagem publicada em 20/03/2011:

4.18

Syria, a police state known for its brutal suppression of any public protests, seemed immune to the wave of uprisings sweeping the Arab world until the past week, when demonstrations took place in several cities.

4.19

Mr. Assad sent a delegation to offer condolences to the families of those killed in the clashes in Dara'a, including the deputy foreign minister, Faisal Mekdad, and Tamer al-Hajeh, the minister of local administration.

4.20

Thousands gathered in and around the Omari mosque in Dara'a, chanting their demands: the release of all political prisoners; trials for those who shot and killed protesters; the abolition of Syria's 48-year emergency law; more freedoms; and an end to pervasive corruption. "No fear after today," the crowd chanted, according to witnesses and human rights activists. 
O mesmo caráter repressivo da reportagem anteriormente analisada pode ser encontrado aqui. No excerto 4.18, o Estado sírio é caracterizado como possuindo uma polícia brutal na repressão de qualquer forma de protesto público. A expressão "known for" vai além de apenas adjetivar o Estado repressor, aplicando a ele o estado conhecido pelo senso comum de um passado, ou uma memória discursiva que confirma o status repressivo do governo antidemocrático.

Em contraste a essa imagem negativa, o excerto 4.19 apresenta o lado humano do presidente Assad, que presta suas condolências às famílias que perderam parentes nos confrontos em Dara. Mas a humanidade de Assad apresentada no excerto se choca com o trecho anterior e funciona mais como uma espécie de ponto de contradição, caracterizando e reforçando a conduta hipócrita da figura do governante.

No excerto 4.20 , confirmam-se as qualificações negativas do inimigo pelas palavras descritas como sendo as palavras do povo. Não mais vemos a voz do repórter, mas sim a voz que vem do povo, evidentemente selecionada e escolhida pela voz da reportagem, para legitimar a figura construída. Essa imagem se constrói pelas seguintes expressões traduzidas: prisioneiros politicos, aqueles que atiraram nos manifestantes e os mataram, abolição da lei de emergência que dura 48 anos, mais liberdade e fim da corrupção. Notamos, emprestada pela voz do povo, a imagem de um governo ditatorial, assassino, repressivo e corrupto.

O excerto ainda termina com uma espécie de palavra de ordem do povo: No fear after today. Nela encontramos o resumo de toda a imagem construída de um regime tirano que vem governando pelo medo. A questão do medo, muito explorada no discurso, é recorrentemente encontrada na história, recorrência principalmente na política. Dentro da cultura americana, citamos como exemplo a frase, comumente atribuída ao terceiro presidente americano e a um dos autores da declaração de independência dos Estados Unidos, Thomas Jefferson: "Quando os governos temem as pessoas, há liberdade. Quando as pessoas temem os governos, há tirania."8

Por fim, analisamos alguns excertos publicados posteriormente ao momento em que a guerra deixa de ser interna, portanto civil, e ganha maior abrangência.

\footnotetext{
8 "When governments fear the people, there is liberty. When the people fear the government, there is tyranny.". Nossa tradução.
} 
Vejamos um artigo de 10/01/2012 que comenta um pronunciamento público do presidente Bashar al-Assad.

4.21

O primeiro parágrafo do artigo usa um paralelismo verbal para resumir o pronunciamento do presidente Bashar e o divide em três partes:

- lashed out the Arab league

- mocked syrian rebels

- vowed to subdue

Os três verbos, de ações verbais, apontam a imagem do enunciador caracterizada pelo ataque. Nesse excerto, segundo o jornal, Bashar ataca a liga árabe, zomba dos rebeldes e promete derrotar aquilo que chama de ataque externo. Além das ações, o texto coloca o presidente em confronto com todos os outros sujeitos: os rebeldes sírios, os países árabes e os americanos.

\subsection{2}

The tenor of his remarks, and his seeming show of confidence, underscored the irreconcilable nature of Syria's crisis, which pits a protest movement demanding that Mr. Assad leave office against a government that rarely acknowledges their grievances.

Esse excerto introduz a leitura do próximo a citar as palavras de Assad; o leitor já é guiado a ler o parágrafo seguinte com pré-julgamento em mente, carregando a imagem de um presidente que não aceita seus erros e suas injustiças e que, por isso, deve deixar o governo. Interessante, a forma como o texto prepara o leitor para as palavras que tratarão especialmente de um discurso direto e que, como vamos notar, estão muito próximas de um discurso conhecido: o americano. 
"When I rule, I rule because that is the people's will, and when I leave office, I leave because it is the people's will," Mr. Assad said.

4.24

"There can be no let-up for terrorism - it must be hit with an iron fist," he said. "The battle with terrorism is a battle for everyone, a national battle, not only the government's battle."

4.25

"There's no tolerance of terrorism or of those who use weapons to kill," he said.

Se lêssemos esses três excertos deslocados de seu contexto, poderíamos dizer, quase seguramente, serem palavras de um discurso americano que enaltece a democracia e luta contra o terrorismo. Mas, como o trecho anteriormente mencionado já nos preparou para a leitura, entendemos tais excertos mais como a retórica demagógica de um tirano dissimulado e mentiroso. O excerto seguinte (4.26) do artigo confirma exatamente o que dissemos:

E, para dirimir definitivamente qualquer dúvida sobre as palavras de Bashar, duas estratégias são usadas: a primeira traz para o discurso uma autoridade contrária ao presidente, e a segunda usa de estatísticas que relatam outras mortes.

\subsection{7}

Mr. Idlibi said in a telephone interview. "They're denying reality. He doesn't want to recognize the changes that occurred until today." 
Even as Mr. Assad spoke, the death toll appeared to rise again. The Local Coordination Committees said on Tuesday that 30 people were killed, including 16 in the eastern city of Deir al-Zour;

Esse texto é bastante eficiente em desconstruir qualquer imagem positiva que porventura possa ser feita de Bashar, pois o discurso reitera a imagem anteriormente descrita, a de um ditador hipócrita e mentiroso.

Analisando a construção discursiva do objeto, Foucault alerta que podemos acreditar que um dado objeto está fora do discurso, ao agruparmos os atos discursivos referentes a ele. Mas, de fato, são as formações discursivas que produzem o objeto. Dreyfus e Rabinow (1995) alegam que o objeto é constituído pelos enunciados que o circundam e que é o discurso e sua relação com outros discurso e com sistemas nãodiscursivos que formam e delineiam o objeto.

Dessa maneira, a figura discursiva do inimigo é construída pelo jornal e se apresenta não como um Bashar al-Assad material, mas sim como um ponto de contradição entre o sujeito que fala e o objeto descrito. Ao descrever o inimigo, o discurso constrói não somente sua própria imagem, mas também a imagem mesma do enunciador, pois essa se opõe à imagem do outro. Todos os valores negativos, como a tirania, o governo do medo e a mentira, são qualificações do inimigo e, portanto, se opõem à imagem do enunciador. Examinamos em nossa próxima análise a construção do sujeito que fala.

\subsection{A construção do sujeito discursivo}

Definidos os objetos da guerra e do inimigo, passamos agora à análise de quem fala. Quem é esse sujeito que tem o direito de dizer? De que maneira esse direito é construído? Em quais circunstâncias e rituais dentro dessa sociedade do discurso?

Foucault (1971) assinala que as instituições formadas e legitimadas nos campos social, político e econômico articulam aquilo que ele chama de discurso da verdade. E esse discurso deve ser levado em conta, porque quem diz tem direito à palavra e obedece a certa ordem, a uma circunstância e a um ritual. Assim, é possível 
compreender o discurso como condição de sujeição ou de rejeição ao discurso institucionalizado.

O autor (1971) ainda afirma haver um ritual no discurso que deve ser satisfeito, qual seja, somente o sujeito que preenche certas exigências e se mostra qualificado para tanto está presente no discurso. Assim, a posição do indivíduo que fala determina todo um comportamento que acompanha o discurso.

Por termos escolhido um jornal norte-americano, acreditamos encontrar em nosso corpus os comportamentos discursivos que dão base à identidade norteamericana, como já observamos anteriormente. O que nos cabe ressaltar é que o jornal The New York Times conta com inúmeras fontes externas, sejam jornalistas de outras nacionalidades, sejam especialistas que contribuem para o jornal. Ainda assim, esses profissionais devem aderir ao discurso fundador americano, base do jornal sob análise. Deixamos para o próximo capítulo a análise da questão da dominação imperial americana em âmbito externo. Para o momento, comprovamos nossa alegação de que os enunciadores do jornal, americanos ou não, compartilham o mesmo ritual discursivo.

Iniciamos a análise com o excerto de um artigo publicado em 27/08/2011 que traz a palavra de um especialista, Vali R. Nasr, professor da Universidade de Tufts, especialista em relações internacionais. Vali é um iraniano que hoje trabalha na John Hopkins University nos Estados-Unidos.

THE Arab Spring is a hopeful chapter in Middle Eastern politics, but the region's history points to darker outcomes. There are no recent examples of extended power-sharing or peaceful transitions to democracy in the Arab world. When dictatorships crack, budding democracies are more than likely to be greeted by violence and paralysis.

Logo no parágrafo de abertura, Vali afirma ser a Primavera Árabe um capítulo esperançoso para a política do Oriente Médio, afirmação essa questionável por nós, porque mencionar esperança é almejar um objetivo, um sonho, um ideal. Há, por parte do enunciador de esperança, um modelo ideal de política para o Oriente Médio, apontado na segunda frase: "democracy". Esse sujeito enunciador possui um valor (democracy) e o estabelece como única possibilidade de modelo político atual. Mas o 
problema é que, por ser objeto de discussão, o Oriente Médio se encontra fora desse modelo ideal objetivado. $\mathrm{E}$ isso aponta para o que dissemos anteriormente.

Sabemos que o conceito atual de democracia é o modelo americano datado da independência. Os princípios iluministas que guiaram todo o processo de independência americana se apoiam no Estado de base contratual de John Locke. $\mathrm{O}$ Estado, para Locke, tem como objetivo proteger aquilo que ele chama de "direitos naturais do homem", definido pelo direito à vida, à liberdade e à busca da felicidade. Esse princípio não somente embasa todas as instituições americanas, mas também se torna modelo para o mundo. Falar em democracia é falar em um Estado de direito que defende tais ideais, modelo esse de democracia que se difundiu em todo mundo e que parece permear todas as discussões de modelos políticos. Locke ainda acrescenta que, se o Estado não cumprir seu papel de defensor desses direitos, é direito do povo destituir seus governantes.

Pensamos, portanto, que esse sujeito discursivo é ideologicamente formado por um modelo iluminista de democracia, base de todas as instituições americanas, que se torna, ao longo da história, o modelo para o mundo ocidental. Não há voz para qualquer outro sujeito que, de uma forma ou de outra, seja constituído por qualquer outra ideologia. Indo um pouco mais além, acreditamos que esse é um modelo epistemológico sobre a compreensão da organização social e política e que qualquer outra forma de pensar ou não seria compreendida, ou seria rechaçada.

Para observarmos novamente esse modelo em ação, tomemos a manchete e alguns trechos de uma reportagem de 19/07/2011 sobre a cidade de Hamas, onde as forças de segurança do governo Bashar não estavam presentes.

\section{In Scarred Syria City, a Vision of a Life Free From Dictators}

HAMA, Syria - In this city that bears the scars of one of the modern Middle East's bloodiest episodes, the revolt against President Bashar al-Assad has begun to help Syrians imagine life after dictatorship as it forges new leaders, organizes its own defense and reckons with a grim past in an uncertain experiment that showcases the forces that could end $\mathrm{Mr}$. Assad's rule.

4.30

Freedom is a word heard often these days in this city, Syria's fourth largest, though that freedom could yet prove elusive. 


Youthful protesters have come together in a group called the Free Ones of Hama,
but it is more a name than an organization. Their real work, activists say, happens in their own
neighborhoods, where they organize shifts to defend barricades, persuade their mothers to cook
stuffed squash for their friends and relentlessly document the uprising with cameras, cellphones
and camcorders.

As principais palavras em todo o artigo são "Life" e "Freedom". Uma está sempre associada à outra numa relação bidirecional de causa e consequência. Como diz a manchete e o lide, as pessoas em Hamas começam a vislumbrar o que seria a vida sem Bashar, já que, no momento da reportagem, as forças do governo tinham se retirado da cidade. O restante do artigo prospecta a ideia da vida longe do controle do governo, e então a palavra "freedom" ganha várias ocorrências, não somente na reportagem, mas também nas ruas, segundo a reportagem. No último trecho, notamos que há uma geração jovem que forma um grupo auto-intitulado de "The Free Ones of Hama".

Um trecho da reportagem que nos despertou a atenção foi o seguinte:

4.32

"Their sons and grandsons are doing the protests today," Abu Muhammad, the former government employee, said.

Aqui há uma referência àqueles que perderam suas vidas lutando pela liberdade do país, sendo os filhos dos que perderam suas vidas no confronto com as forças do governo que hoje protestam. De certa forma, há indiretamente uma referência à continuidade de um ideal de liberdade iniciado em uma geração anterior. Notamos certa similaridade com a ideia dos "pilgrim fathers", aqueles que vieram à América para construir uma nova sociedade, na qual a justiça, os ideais de igualdade e a luta por construir um mundo novo dão base à formação dos Estados Unidos. A ideia de que filhos e netos continuam o legado iniciado por seus ancestrais na construção de um mundo novo é bastante explorada nos discursos americanos e utilizada em nossa reportagem. Outro detalhe é que a informação é creditada a um ex-funcionário do governo sírio, que agora aparece ao lado dos rebeldes, o que pode ser compreendido como uma mudança ideológica já em curso. Aqueles que apoiavam 
o governo, por ideologia ou simplesmente por sobrevivência, passam a ter outra perspectiva em que se apoiar, colocando-se ao lado da vida e da liberdade.

Por fim, analisamos um último texto no qual o escritor alemão Jürgen Todenhöfer, ex-juiz, militante anti-guerra e crítico das políticas ocidentais para o mundo árabe e islâmico, consegue uma entrevista com o presidente Bashar sobre qual seria a perspectiva do presidente sírio acerca dos conflitos. Escolhemos esse artigo por trazer uma voz contrária àquela da crítica a Bashar. Ressaltamos que não analisamos a entrevista em si, mas sim uma reportagem que noticia a entrevista e seus efeitos.

Logo após a manchete, transcrita abaixo, há uma foto de Bashar com o alemão e a legenda: “Jürgen Todenhöfer had a highly scrutinized interview with Syria's president, Bashar al-Assad, in July. "They said, 'You speak to dictators," Mr. Todenhöfer said of his opportunity." Nessa legenda, já se encontra um pouco do teor daquilo que consideraremos em todo o texto: a voz que dialoga com esse escritor está representada na legenda pelo pronome "They". Essa voz parece aproximar-se do sujeito discursivo de nossa análise e coloca-se contra essa entrevista, alegando que a entrevista funcionaria como uma espécie de propaganda de Bashar, que repetidamente mentiria sobre os fatos. O que nos interessa aqui não é a voz do escritor na entrevista, muito menos a voz de Bashar, mas sim a que é representada por esse pronome "they". Vejamos alguns trechos que mostram a presença dessa voz e o sentido trazido ao texto.

4.33

\section{Writer Defends His Handling of Interview With Assad}

(...) And he has castigated Western press coverage of the Syrian conflict, calling it unfairly hostile to Mr. Assad and overly sympathetic to his enemies.

Nesse primeiro trecho da reportagem, o texto deixar clara a posição assumida pelo escritor, colocando-o não ao lado de Bashar, nem sequer ao lado de seus opositores. A posição dada ao alemão, que será reforçada mais adiante, é a de alguém que busca compreender a guerra a partir de uma perspectiva mais ampla do que aquela sugerida do um contra o outro.

A partir de então, o artigo apresenta alguns comentários acerca da entrevista de Bashar, como vemos a seguir numa edição do texto: 

him. He also referred to all armed opponents as terrorists and accused other Arab countries, and the United States, of abetting them with weapons and supplies. portrayed by his enemies, blaming them for the litany of atrocities, including massacres of women and children, that have punctuated the conflict.

Nesses dois trechos, apesar do que diz o escritor alemão, o enunciador faz com que a imagem do presidente Bashar se encaixe no pré-construído, em conformidade com a figura examinada anteriormente. A imagem de um ditador que não reconhece como legítima a voz que vem do povo é dada no primeiro trecho. No segundo, encontramos a imagem do falso e do mentiroso, revelada pela transferência da culpa, aquilo a que o texto chama de "mirror image", segundo a qual Bashar transfere aos rebeldes a responsabilidade pelos massacres acontecidos na Síria.

Há ainda uma crítica feita pelo presidente, que coloca os americanos e países árabes que os apoiam no mesmo patamar daquilo que ele chama de terroristas. Evidentemente, o texto não valida as palavras de Bashar, mas as usa para fortalecer a imagem pré-construída do governante e desmerecer as afirmações feitas pelo escritor alemão. Essa voz, que reporta a entrevista, é a mesma construída anteriormente e se alinha com todo o discurso que analisamos.

Para amenizar ou quem sabe tirar a legitimidade da voz contrária de Jürgen, a reportagem apresenta algumas construções textuais, como vemos no próximo excerto (4.36), as quais buscam, dentro do próprio discurso de Todenhöfer, pontos de apoio que sustentariam o discurso proposto pelo sujeito da análise.

Speaking by telephone from Munich, his home, Mr. Todenhöfer said the Syrian conflict had been distorted by half-truths and fictions - much of it, in his opinion, by the opposition figures who want the world to see Mr. Assad as a butcher. "Lying is the most effective weapon in wars," he said. 
Ao dizer que a mentira é a mais ponderosa arma na guerra, o sujeito discursivo usa das palavras do escritor não para referir-se à oposição, como cremos ser a intencionalidade de Todenhöfer, mas sim para reforçar a imagem de mentiroso do próprio Bashar, já que anteriormente a própria reportagem assim a havia descrito.

O texto faz um recorte bem específico das palavras do escritor e as usa em forma de discurso direto. O texto abaixo aponta que, no momento presente, diferentemente das vivências anteriores do alemão no Oriente Médio, até o próprio Jürgen admite algo ter mudado na Síria, o qual, em sua opinião, pode ser entendido como uma tragédia sem solução.

4.37

Now, Mr. Todenhöfer conceded, such an outcome no longer seemed possible. "There is something which is changing now in Syria; for me it is a terrible tragedy," he said, adding, "a classic tragedy without a clear solution."

Logo em seguida, emerge outra voz, contrária à do escritor e alinhada com o discurso hegemônico que estamos tentando construir. Trata-se dos opositores de Todenhöfer.

4.38

Many others disagree. At a debate organized by the German weekly newsmagazine Der Spiegel in late July, after the Assad interview was broadcast, Christoph Reuter, Der Spiegel's veteran Syria correspondent, called Mr. Todenhöfer's conclusions absurd and also rejected his view that Mr. Assad is interested in compromise.

4.39

Mr. Todenhöfer faulted Mr. Reuter and other Western journalists for what he called their willingness to accept the rebel narrative, with its uncorroborated casualty reports, unverified videos of destruction and anonymous witnesses to atrocities by soldiers and thuggish militiamen. "I criticize their disinformation campaigns and their dreadful 'massacre marketing,' he said.I

4.40

Some of Mr. Todenhöfer's critics in Germany said the interview was a selfindulgent exercise that had allowed the Syrian president to convey false humanity. "One 
can easily fall into traps, as Todenhöfer's interview with Assad shows," said a commentary in Die Welt, a conservative national daily.

Bastante interessante de se observar aqui é que essas vozes são muitas e estão, todas elas, em oposição à voz única de Jürgen. São elas:

- Many others disagree

- Christoph Reuter

- Western journalists

- $\quad$ Some of Mr. Todenhöfer's critics

O que essas vozes afirmam classifica as ideias do escritor alemão como absurdas e a entrevista como uma armadilha que possibilitou ao "ditador" apresentar uma imagem de falsa humanidade. Pode-se até pensar, pelo encadeamento da argumentação, que a entrevista foi um erro de Todenhöfer.

Por último, no final da reportagem, há novamente a voz do escritor por meio de cujas palavras, em discurso direto, percebemos que a ideia defendida pode ser vista como um idealismo, uma utopia. Todos sabemos, e os ditados populares atestam, que a guerra é estúpida e sempre se perde na guerra, mas também temos a certeza de sua inevitabilidade. Assim, qualquer discurso antiguerra pode ser visto como idealista e utópico, assim como aquele que o profere. Segue o excerto:

4.41

Mr. Todenhöfer said he wrote the book to convey what he called the stupidity of war. "When you see the victims, you cannot be for a war," he said. "War is always a defeat."

Nesse excerto de nosso corpus, uma voz diferente parece soar no discurso, mas ela é rapidamente incluída, classificada e desconstruída. Não há uma negação dela, mas uma tentativa de colocá-la no plano da imaterialidade ao fazer com que ela pertença a um discurso idealista.

Foucault (1971) propõe que uma análise seja baseada, primeiramente, nas formas de exclusão, apropriação e limitação do discurso e, em seguida, na observação de um conjunto "genealógico" que investigue como esses discursos se estabeleceram baseados em sistemas de coerção. 
O autor, conforme Dreyfus e Rabinow (1995), aponta a existência de um desejo de conhecer a verdade, razão porque tentamos transformar quaisquer atos discursivos do cotidiano em "atos discursivos sérios". Dessa maneira, atos discursivos são constantemente validados e negados com a pretensão de transformá-los em um saber a fim de esses atos serem repetidos e transmitidos. São atos discursivos com aspiração a verdades.

O que percebemos em nossa análise sobre a construção do sujeito que fala é haver uma verdade construída baseada em um modelo de organização política formado no iluminismo e que tem os Estados Unidos como seu maior expoente. Esse modelo tem como princípio um Estado contratual defensor dos chamados direitos naturais do homem: a vida, a liberdade e a busca pela felicidade. Vimos também que qualquer tentativa de supressão desses direitos dá ao povo o direito de se rebelar.

O sujeito que fala deve, portanto, falar de dentro dessa posição legítima, ou seja, deve pertencer a essa sociedade discursiva. Desse modo, essa posição é dada discursivamente, e o alinhamento a esse discurso imprime ao sujeito enunciador o direito à palavra. Qualquer outra forma, como vimos, que não se alinhe a esse discurso não é eliminada nem aniquilada, mas está condenada a viver na imaterialidade, em um mundo de aspirações ingênuas e idealistas, distantes da realidade e da materialidade do acontecimento. Como diz Foucault (1971), o discurso precede o sujeito.

\subsection{As polêmicas e as contradições do discurso político}

Em referência ao discurso político, Courtine (2006) afirma ser ele interativo, polêmico e conflituoso, devendo, por isso, ser visto sempre por meio de suas contradições ideológicas e de seus enfrentamentos. Dessa maneira contraditória, o dizer político não se apresenta a partir de uma escolha do sujeito, mas a partir de um conjunto de posições de sujeito ou modos diferentes de enunciação.

Investigamos, nessa parte da pesquisa, quais são as formas de persuasão da opinião pública que visam à adesão dos cidadãos a um projeto político que tem como objetivo a legitimidade da ação política por meio da devida construção jurídica.

Como afirma Courtine (2006), o discurso político é contraditório e polêmico. 
Em um país como os Estados Unidos, historicamente constituído por uma série de dicotomias, como a oposição norte/sul, republicanos e democratas, liberais e conservadores, o campo das crenças, dos valores e das ideias é igualmente contraditório e polêmico. Contudo pensamos que, acima das dicotomias, há um projeto nacional arraigado na formação do País o qual advém dos ideais puritanos, desenvolve-se no iluminismo e se aprimora ao longo da história. Esse projeto transcende qualquer bipartidarismo político ou ideológico e está fincado na maneira como o americano, independentemente de sua posição política, percebe e julga a realidade que o cerca.

Partimos da ideia de que qualquer forma de persuasão usada no discurso político que evoque esse projeto nacional é uma estratégia efetiva de convencimento tanto da instância política quanto da de seus adversários ideológicos. Examinamos, nesse momento, como isso acontece internamente nos Estados Unidos.

Primeiramente, gostaríamos de demonstrar a variedade de opiniões internas nas diversas instâncias americanas sobre a guerra da Síria. Uma polaridade sempre presente nos artigos de nosso corpus é a oposição presidente $x$ congresso. Vejamos, então, o primeiro excerto de 07/03/2013:

All along, it's been clear that President Obama has nothing but bad options in Syria's civil war. Now, though, he's found a way to put Congress in a similarly unfortunate position.

Esse excerto ilustra o que acabamos de mencionar. O colunista, Ross Douthat, examina as opções difíceis sobre a guerra na Síria que se colocam para o presidente Obama, como chefe de estado. Ao afirmar que Obama agora também coloca o Congresso em uma situação difícil, o colunista estabelece a contradição de opiniões Obama $X$ Congresso americano. Ora, se entendermos que a situação difícil do congresso americano só começa agora, então podemos concluir que a situação anterior era confortável, apenas difícil para o presidente. Há uma desigualdade anterior que parece agora ter sido corrigida por uma ação de ataque do governo Obama. 


\begin{abstract}
When the House and Senate vote on whether to authorize strikes on Bashar al-Assad, they'll be choosing between two potentially disastrous paths: either endorse a quasi-war that many constituents oppose and that this White House seems incapable of justifying on the merits, or vote to basically finish off the current American president as a credible actor on the world stage.
\end{abstract}

Nesse artigo, descreve-se e comenta-se o processo de autorização de um ataque a Bashar al-Assad que está em votação na Câmara e Senado. No excerto 4.43, o autor aponta dois possíveis caminhos e chama-os de "disastrous", na tentativa de chegar à conclusão de que não há caminho seguro. De certa forma, o texto atribui esses caminhos incertos a Obama, como se o presidente não tivesse opção segura, mas sim apenas possibilidades de ações desastrosas em qualquer caminho. Agora esse dilema presidencial se desloca para a Câmara e o Senado. Temos uma impressão de que está implícita a afirmação de que, quando se está fora da Casa Branca, é fácil criticar as decisões, mas, quando a questão está na pauta de discussão de outras instâncias, todos sentem a pressão. Os deputados e senadores devem ou apoiar a guerra ou, ao votar contrariamente, ajudar na construção de uma imagem internacional positiva do presidente Obama.

Os dois excertos imediatamente mencionados fornecem o claro exemplo de que há internamente um jogo de forças e de opiniões com relação à atuação americana na guerra. Não percebemos na leitura de nosso corpus uniformidade de opiniões entre os diversos atores políticos americanos. Na verdade, trata-se de estratégias políticas, como veremos a seguir.

4.44

The second option seemed relatively unlikely a week ago, but now - in the House especially - it looks like a live possibility. The politics of a "yes" vote are lousy: the bases of both parties are opposed, the public in general is skeptical, and the president isn't popular enough to provide cover for legislators worried about how another military adventure would play back home.

Optamos por adicionar um terceiro excerto do mesmo artigo para demonstrar que a questão da interferência na Síria tem menos relação com a Síria ou com a questão humanitária e muito mais com a construção de uma imagem pública positiva do político em si. O que observamos é que a opinião em si tem bem pouca 
importância; o que se leva em conta é o efeito que essa opinião e a ação dela decorrente pode ocasionar na imagem política para a opinião publica. $\mathrm{O}$ trecho afirma que uma mudança de opinião é muito provável, considerando-se que a aprovação a uma intervenção militar na Síria poderia, num governo não muito popular, ter consequências negativas no âmbito doméstico.

Tanto os Estados Unidos quanto o Reino Unido, apesar de favoráveis à intervenção, inicialmente procuraram evitá-la. É que eles temiam uma reação contrária da opinião pública que, entre outras coisas, receava viver tanto a reprodução do conflito vivido no Iraque, quanto a ameaça de que as armas pudessem cair em mãos islâmicas, principalmente nas mãos da Al-Qaeda.

A política externa de uma nação pode ser vista como um diálogo constante entre seus líderes e a opinião pública, política essa influenciada pelo debate midiático. Os textos sobre questões internacionais produzidos pela mídia tornam-se, então, práticas políticas que, por meio de construções discursivas, produzem sentidos sobre a política, a economia, a cultura e as sociedades nacional e internacional.

Baum e Potter (2008) admitem que, no âmbito da política externa, a mídia possui um papel essencial à mudança de dinâmicas. Em primeiro lugar, porque a principal ligação entre lideranças e público é a mídia, central nesse mercado político. Em segundo lugar, porque ela funciona como mediadora do fluxo de informações quando há um conflito de interesses.

Apresentados os conflitos internos, que comprovam a presença de uma pluralidade de discursos, inquirimos agora a questão proposta no início desta análise: a presença de um projeto nacional que estaria acima da característica polêmica e contraditória do discurso político. Introduzimos a discussão com uma carta ao editor, publicada no jornal em 14/06/2013.

I believe that Americans and Europeans will very much regret that we have waited so long to intervene on behalf of the Syrian rebels.

More than $\mathbf{9 0 , 0 0 0}$ people have already died, and thousands have been tortured in Bashar al-Assad's prisons. Now that President Obama has made the decision to send weapons to the rebels, I hope that he does this decisively and vigorously and that European countries join us so that one of the worst dictators in the world is removed from power and Syria has a chance of becoming a democratic country. 


\section{DOUG KORTY}

Lebanon, Ind., June 14, 2013

Nessa carta, de um leitor do Líbano, o texto questiona a demora de americanos e europeus no apoio aos rebeldes. Cita como consequências as mortes e as torturas recorrentes no país e conclui dizendo que a Síria precisa se livrar de um dos piores ditadores do mundo para ter a chance de se tornar um país democrático. No texto, encontramos o tom humanístico que valoriza a vida, a liberdade e a democracia, ligando esses princípios aos três atores em questão: americanos, europeus e rebeldes. São exatamente esses os valores acionais do projeto americano encontrados por nós. Examinamos, a partir das próprias palavras de Barack Obama publicadas no jornal do dia 19/05/2011, uma discussão interna acerca desse projeto. Recortamos alguns trechos para nossa análise:

4.46

The syrian government must stop shooting demonstrators and allow peaceful protests. it must release political prisoners and stop unjust arrests. it must allow human rights monitors to have access to cities like dara'a; and start a serious dialogue to advance a democratic transition. otherwise, president assad and his regime will continue to be challenged from within and will continue to be isolated abroad.

4.47

our message is simple: if you take the risks that reform entails, you will have the full support of the united states.

4.48

those words must guide our response to the change that is transforming the middle east and north africa -- words which tell us that repression will fail, and that tyrants will fall, and that every man and woman is endowed with certain inalienable rights.

O discurso do presidente Obama é repleto de vontades e palavras de ordem, conforme se observa nos trechos a seguir:

a) must stop shooting demonstrators 
b) stop unjust arrests

c) must allow human rights monitors to have access to cities like Dara'a

d) start a serious dialogue to advance a democratic transition.

Podemos observar o uso tanto do modal "must" com sujeito de terceira pessoa, quanto do imperativo, ambos os quais implicam que as ações não são ou serão realizadas por aquele que fala, mas sim por um terceiro que está fora da cena enunciativa. Nesses trechos, o enunciatário não se compromete, nominalmente, com uma ação.

Além disso, o uso do modal "will" pode ser visto como uma previsão de futuro, e não como um posicionamento do falante. Ao enunciar que "It will rain", o homem do tempo não realiza a ação da chuva; apenas se compromete com a previsão de que um "terceiro" irá chover.

No final do excerto 4.46 e nos excertos 4.47 e 4.48 , encontramos os seguintes trechos:

a) his regime will continue to be challenged from within and will continue to be isolated abroad;

b) If you take the risks that reform entails, you will have the full support of the United States;

c) repression will fail;

d) tyrants will fall.

Observamos nesse discurso do presidente muito mais a vontade da ação do que ação em si. No âmbito do discurso, percebemos que todos os ideais americanos aderidos à imagem americana são declarados. $O$ direito à vida, à liberdade e à busca pela felicidade é reiterado no discurso do Presidente Obama. Se colocarmos o reverso das proposições do presidente, veremos o discurso do antagonista, sintetizadas em tirania, violência e resistência.

Para analisar agora um discurso antagônico, ao menos no âmbito político, selecionamos o seguinte artigo, publicado em 28/06/2011: 
In his speech, Mr. Pawlenty mocked that approach. He called Mr. Obama "timid and slow" when it came to responding aggressively to world events. And he said the Republican Party should not join Mr. Obama in shrinking from the challenges to American leadership.

Membro do partido republicano, Tim Pawlenty chama a política de Obama para o Oriente Médio de um fracasso. Se pensarmos que o governo estava extremamente cauteloso e lento em suas ações, a fala do republicano endossa uma efetiva mudança de rumos. É muito comum questões internas de caráter polêmico serem levadas em "banho-maria", pois se espera que aconteça uma mudança na opinião publica que legitime a tomada de ação previamente desejada. Para o político, Obama não está exercendo a liderança que se espera dos americanos. Com essa fala, o político legitima, pelo menos do lado republicano, uma ação mais agressiva do governo.

Ao pensarmos que o político sugere uma ação, nos questionamos sobre suas motivações, e caímos novamente no projeto nacional defendido tanto por Obama, quanto por seu adversário político republicano. Para percebermos que o projeto nacional é o mesmo, selecionamos dois trechos reveladores da perspectiva republicana que se conformaram à fala de Obama. O primeiro é um artigo de 29/05/2012, que apresenta as opiniões do candidato republicano à presidência da república, Mitt Romney; o segundo é a transcrição de um discurso do mesmo Romney, publicada no jornal The New York Times no dia 08/10/2012.

WASHINGTON - The massacre of more than 100 civilians, many of them children, in Syria over the weekend has presented Mitt Romney with a new opportunity to sound a familiar theme: that President Obama's foreign policy is feckless and lacking in courage.

Mr. Romney, the presumptive Republican presidential nominee, condemned Mr. Obama on Tuesday for a "policy of paralysis" toward Syria that he said had allowed President Bashar al-Assad to "slaughter 10,000 individuals."

4.51

This is the struggle that's now shaken the entire Middle East. It's the struggle of millions and millions of people -- men and women, young and old, Muslims, Christians and nonbelievers -- all of whom have had enough of the darkness. It's a struggle for the dignity that 
comes with freedom and opportunity and the right to live under laws of our own making. It's a struggle that's been unfolded under green banners in the streets of Iran, in the public squares of Tunisia and Egypt and Yemen, and in the fights for liberty in Iraq and Afghanistan and Libya, and now in Syria.

In short, it's a struggle between liberty and tyranny, justice and oppression, hope and despair.

$(\ldots)$

We've seen this struggle before. It would be familiar to General George Marshall. In his time, the ashes of world war, another critical part of the world was torn between democracy and despotism.

O primeiro trecho comenta o oportunismo do candidato Romney, que, ao ver um massacre ocorrido na Síria, aproveita para culpar o governo Obama. Segundo o candidato, esse fato seria uma prova da falta de coragem do presidente, isto é, daquilo que ele chama de política externa de "paralisia". Ao notar essa crítica à política externa do governo Obama, nos perguntamos qual opinião ele defende. Se pensarmos em termos de oposições, entendemos que sua política seria uma política de ações corajosas que pudessem por fim ao conflito e às ameaças advindas do mundo árabe. O segundo trecho expõe, em nível ideológico, as ideias de Romney. Vejamos algumas expressões:

- It's a struggle for the dignity that comes with freedom and opportunity and the right to live under laws of our own making;

- $\quad$ the fights for liberty;

- $\quad$ it's a struggle between liberty and tyranny, justice and oppression, hope and despair;

- $\quad$ between democracy and despotism.

Os quatro trechos exibem claramente que os valores defendidos pelo republicano são liberdade, justiça, esperança e democracia, valores ideológicos absolutamente idênticos aos proferidos pelo presidente Obama. Isso retoma a questão que nos colocamos anteriormente: apesar de diferentes formas de falar ou de agir, o projeto nacional americano fica garantido nas mãos ou de democratas, ou de republicanos. Há, como mencionamos anteriormente, uma construção ideológica nacional que data da formação do país e que antecede qualquer discurso. Não importa se quem fala é democrata, republicano, conservador, liberal, de direita, de centro ou 
de esquerda; a formação discursiva é a mesma, advinda de um projeto de país constantemente reiterado em todos os discursos nacionais.

Resgatando o que dissemos anteriormente, esse projeto nacional possui status de uma episteme que constrói um saber sobre a vida em sociedade, a partir do qual se originam muitos outros discursos, nas mais variadas áreas e campos do saber. A maneira de agir pode, sim, mudar, e as palavras podem, sim, aderir a outros discursos, mas nunca perdem seu discurso fundador, que sempre será a base epistemológica da produção da verdade e do saber.

Neste capítulo, defendemos a existência de uma ideologia que permeia toda a produção discursiva sobre a guerra na Síria. Tanto a mídia como os atores políticos envolvidos nesse discurso são constituídos em sujeitos pelo próprio discurso. Observamos que a heterogeneidade do discurso político carrega aderências a um discurso presente em qualquer instância discursiva.

A construção do objeto - seja ele a própria guerra, seja o inimigo - e a posição daquele que tem o direito à fala obedecem à mesma formação discursiva. Essa formação discursiva, advinda de uma ideologia presente na base da formação americana, constrói um saber sobre a realidade social que permeia todo o pensamento e toda a compreensão do mundo americana.

Não estamos afirmando, entretanto, que essa episteme é homogênea e única. Se há uma crítica ao modo de agir dos Estados Unidos e se os conflitos no Oriente Médio existem e ameaçam a ideologia americana, é porque esses (crítica e conflitos) estão em um circulo discursivo exterior à compreensão americana iluminista da realidade, fazendo com que exista uma espécie de resistência a esse discurso nacional americano, que oportunamente chamamos, para usar as ideias de Hardt e Negri (2001), de Império.

No próximo capítulo, discutimos melhor a questão do Império americano no mundo, esclarecendo de que forma as relações Oriente/ Ocidente se estabelecem e quais mecanismos os Estados Unidos exploram para estabelecer sua soberania em nível global. 


\title{
CAPÍTULO 5: DAS QUESTÕES SOBRE O ORIENTE E O OCIDENTE
}

\begin{abstract}
Os crimes contra os direitos humanos, especialidade dos regimes totalitários, podem sempre justificar-se pela desculpa de que o direito equivale ao que é bom ou útil para um todo, em contraste com as suas partes. (O lema de Hitler, de que "o direito é aquilo que é bom para o alemão" é apenas a forma vulgar de uma concepção da lei que pode ser encontrada em toda parte (...))
\end{abstract}

(ARENDT, 1951, p.428)

A partir das condições de produção do discurso, objeto de estudo deste trabalho, elencamos neste capítulo algumas questões específicas sobre como funcionam certos aspectos sociais que emergem no discurso sobre a guerra. $\mathrm{O}$ foco serão as questões políticas, sociais e culturais que permeiam a construção discursiva sobre cobertura da guerra na Síria e que possam tanto exemplificar o ressoar do dizer de um projeto nacional ocidental em âmbito global, quanto demonstrar as relações existentes entre os Estados Unidos e o Oriente.

Iniciamos o capítulo, tematizando a construção discursiva daquilo que Hardt e Negri (2001) chamam de Império. Para isso, focamos nossa analise no discurso que vem ligado ao papel da ONU e a sua constituição ideológica. Posteriormente, analisamos como o discurso engendra a imagem de soberania da instituição que aparece extremamente vinculada a um projeto de soberania americana datado de sua formação. Embora fiquemos restritos à questão americana por ser esse o objeto de estudo deste trabalho, devemos lembrar que os Estados Unidos não são a única fonte desse discurso, já que encontramos origens possivelmente vinculadas à revolução francesa.

Na sequência de nossas exposições, analisamos de que maneira o discurso apresenta o projeto de expansão americano, que estabelece uma relação conflituosa com o Oriente Médio. A seguir, centramos a discussão na materialização discursiva daquilo que Chomsky (1999) chama de "Rogue States". Temos por objetivo investigar a imagem do "Império do mal" construído pela narrativa da guerra e da subjugação do Oriente. Finalmente, traçamos um panorama que nos permite sustentar a hipótese de que o discurso da guerra viabiliza a fabricação da aquiescência legitimadora da 
intervenção ocidental e coloca em ação o plano de soberania hegemônica do Ocidente.

\subsection{O Papel da ONU e sua organização ideológica}

Iniciamos essa parte de nosso trabalho esclarecendo aquilo que Hardt e Negri (2001) chamam de Império e qual o papel das Nações Unidas em sua constituição.

Michael Hardt e Antonio Negri (2001) chamam de Império a atual forma da economia mundial, em que a soberania do Estado-nação é colocada em xeque por sua incapacidade de regular as trocas econômico-culturais. Nesse sentido, a palavra Império é usada metaforicamente, sem referência a fronteiras nem a nações, mas sim a um "aparelho de descentralização e desterritorialização do geral que incorpora gradualmente o mundo inteiro dentro de suas fronteiras abertas e em expansão." (HARDT, M.; NEGRI, A., 2000, p.12)

Em sua constituição, a origem desse Império, segundo esses autores, constituiu-se juridicamente, tendo a ONU teve papel essencial em sua formação. Criada a princípio para manter a segurança mundial, as Nações Unidas acabam por promover um "constitucionalismo global" que legitima o Império.

A Declaração Universal dos Direitos Humanos é exemplo desse constitucionalismo "Imperial". Segundo Clark (1997), a declaração é dominada por preocupações, interesses e valores de um segmento bastante pequeno e rico, como Estados Unidos, Inglaterra e França, que compõe as Nações Unidas. A declaração, segundo o autor, explicita ideias que enfatizam direitos políticos enraizados na longa história desses países.

Arendt (1951) observa que há, desde a princípio da Declaração dos Direitos Humanos, um paradoxo contido nela. Ela se refere a um ser humano "abstrato", a um homem que não existe, pois, segundo a autora, até os homens primitivos viviam dentro de uma determinada ordem social. E se um grupo de homens "atrasados" não tinha garantia de seus direitos é porque esses homens não tinham ainda atingido certo grau de civilização. Dessa forma, os direitos dos homens estariam ligados a uma ideia de povo, de um Estado-nação, nos moldes da pós-Revolução Francesa, e não ao indivíduo em si. A autora afirma também que os direitos humanos proclamados pela 
Revolução Francesa e pela Americana nunca foram uma questão prática. Eram invocados para diminuir a insegurança nacional em conflitos, ou para defender certos indivíduos do poder crescente do Estado.

Para início de nossa análise, e baseando-nos no documento dos direitos humanos, apontamos que há, inicialmente, a necessidade de atribuir à Síria um status que possa ser jurisdicionado por essa lei. Como mencionamos anteriormente, a lei tem um caráter global e, portanto, pode e deve ser aplicada em qualquer local onde ela tenha sido foi violada. Há, entretanto, a emergência de declarar a sua violação para que seu constitucionalismo possa ser aplicado e sucessivas ações possam se desenvolver. Nos excertos abaixo, todos da mesma matéria publicada em 12/05/2011 sob o título de Signs of Chaos in Syria's Intense Crackdown, observamos as justificativas constitucionais para que a lei possa ser legitimada em território sírio.

5.1

Residents have reported that hundreds of detainees are being held in soccer stadiums, schools and government buildings in various towns and cities across the country, some of them arrested in door-to-door raids by black-clad forces carrying lists of activists.

5.2

Others have said the arrests are often arbitrary, sometimes for little more than a tattered identity card, in a campaign that seems motivated to bully people to stay indoors and to restore a measure of the fear that has buttressed the Assad family's four decades of rule. Many men have been forced to sign a pledge not to protest again, residents said.

"The reaction of the authorities has excluded any possibility of having a rational solution," said Rassem al-Atassi, the president of the Arab Association for Human Rights in Syria, in Homs, the country's third largest-city and a center of the uprising.

5.3

The brutality of the repression has led the United States and the European Union to impose some sanctions on figures in the leadership, though not on Mr. Assad himself.

5.4

Mrs. Clinton said that the United States would now pursue "additional steps to hold Syria responsible for its gross human rights abuses."

"There may be some who think this is a sign of strength," she said, "but treating one's own people in this way is in fact a sign of remarkable weakness." 
Logo do primeiro excerto (5.1), o texto denuncia a questão da supressão da liberdade, ao afirmar que há cidadãos sendo detidos por suspeita de envolvimento político e que muitas dessas prisões, baseadas numa lista de ativistas, são, de acordo com o segundo excerto (5.2), arbitrárias. O texto ainda atribui às forças do governo Assad tentativas de estabelecer um clima de medo, por obrigar muitas vezes os cidadãos a assinarem a promessa de não se envolverem novamente com protestos. Essa primeira parte do texto projeta claramente o estado de supressão de direitos garantidos pela Declaração dos Direitos Humanos, tais como a liberdade e a justiça. O artigo 9 da Declaração afirma que "Ninguém pode ser arbitrariamente preso, detido ou exilado", e convém notar que o excerto do jornal faz exatamente o mesmo uso da palavra "arbitrária", numa relação intertextual direta com a forma da lei.

Observamos ainda que o artigo 12 da declaração explicita que:

\footnotetext{
Ninguém sofrerá intromissões arbitrárias na sua vida privada, na sua família, no seu domicílio ou na sua correspondência, nem ataques à sua honra e reputação. Contra tais intromissões ou ataques toda pessoa tem direito à proteção da lei.
}

Nesse sentido, podemos admitir mais uma violação que o excerto deixa transparecer ao mencionar, contrariando o artigo da Declaração, que "some of them arrested in door-to-door raids by black-clad forces carrying lists of activists."

Nos próximos excertos, revela-se a descrição da intensidade das ações da força policial síria, a qual fortalece a ideia de quebra da lei. Em primeiro lugar, as autoridades são descritas como irracionais por um ativista dos direitos humanos na Síria, o que dá credibilidade à informação. A seguir, o texto usa duas adjetivações, "brutality" e "gross", que, como dissemos, intensificam a violação dos direitos humanos e dão maior dramaticidade a ela. Por fim, e não menos importante, esses atributos têm origem na voz de uma americana, Hillary Clinton, que reitera e endossa toda a dramaticidade da ação da polícia síria sob o comando de Bashar.

Todo esse discurso visa tanto a deflagrar a violação das leis internacionais, como a validar a constitucionalidade da declaração dos direitos humanos. Ao levar essas declarações à opinião pública, o texto instaura um estado de direito na Síria baseado em um constitucionalismo internacional, sendo ou não a Síria membro das Nações Unidas. 
Essas mesmas características estão presentes no editorial do jornal publicado em 03/06/2011, dessa vez um artigo de opinião do próprio jornal, e não uma reportagem, como da outra vez. Gostaríamos nesse momento de analisar a incidência de palavras e expressões que endossam o quadro anteriormente construído. São, elas todas, do mesmo artigo:

\section{5}

\begin{tabular}{|l|}
\hline reign of terror \\
\hline escapes strong condemnation \\
\hline real punishment \\
\hline protesters have been killed \\
\hline have been arrested \\
\hline tortured body \\
\hline brutality \\
\hline murder \\
\hline Mr. Assad and his thugs \\
\hline protesters were killed \\
\hline journalists are barred \\
\hline vicious \\
\hline After the killing \\
\hline condemn the bloodshed \\
\hline shameful stance for a democracy
\end{tabular}

Em todo o texto, encontramos expressões que dramatizam a situação dos protestos na Síria, todas elas ligadas ao cenário de uma guerra bárbara promovida por um governo, segundo o artigo, ilegítimo e brutal. Um dado relevante para nós nesse editorial é a demanda que o texto faz por uma ação mais efetiva dos Estados Unidos e do Conselho de Segurança da ONU.

5.6

After the killing began, the United States and Europe imposed sanctions - mostly travel bans and asset freezes - on certain key regime officials while exempting Mr. Assad. Only later did they add his name to the list. The rhetoric is stiffening.

5.7

Most appalling, the United Nations Security Council is unable to muster the votes to condemn the bloodshed much less impose sanctions. 
Há uma crítica sobre como o País e a instituição estão agindo em relação ao assunto. O próprio jornal, por meio de seu editorial, se posiciona como opinião pública que observa o cenário de barbárie e se posiciona contra o governo Bashar e a favor da aplicação mais rigorosa da lei. Segundo nossa percepção, há um apelo a essas duas partes da declaração: o primeiro, um trecho do preâmbulo que diz:

Considerando que os Estados-Membros se comprometeram a promover, em cooperação com as Nações Unidas, o respeito universal aos direitos humanos e às liberdades fundamentais e a observância desses direitos e liberdades

O segundo, artigo 28 da Declaração, que diz: "Toda pessoa tem direito a uma ordem social e internacional em que os direitos e liberdades estabelecidos na presente Declaração possam ser plenamente realizados."

O jornal passa a representar uma espécie de voz internacional que, mesmo contrariando seu próprio País ou os dirigentes das Nações Unidas, objetiva denunciar, fazer conhecer, fiscalizar a gerência dos direitos promovidos pela Declaração, além de opinar sobre essa gerência. Nesse caso, contrário não significa um embate direto, mas sim uma forma de garantir que o projeto contido no documento possa ser priorizado em detrimento de quaisquer interesses políticos ou econômicos. O jornal adquire, com essa postura, uma qualidade que extrapola as fronteiras nacionais e passa a funcionar como um discurso que, independentemente de sua origem nacional, tem por função garantir um projeto ideológico maior.

Assim admitido, voltamos ao que construímos anteriormente; o projeto ideológico ocidental, muito similar ao próprio projeto de nação americana, que se propaga por todo o mundo, ganhando voz e visibilidade e anunciando, mais uma vez, seu caráter epistemológico.

A análise realizada já aponta o que será discutido em nossa próxima categoria, a noção de soberania das Nações Unidas e seu vínculo discursivo com o projeto americano. Ao adquirir uma voz acima das fronteiras nacionais, a ONU legitima um papel regulatório de todos os movimentos de tensão internacionais, transforma-

\footnotetext{
${ }^{9}$ http://www.direitoshumanos.usp.br/index.php/Declara\%C3\%A7\%C3\%A3o-Universal-dos-DireitosHumanos/declaracao-universal-dos-direitos-humanos.html
} 
se, portanto em uma instituição chave para a resolução de conflitos, quer pelos mecanismos diplomáticos, quer pela autorização para o uso da força. Por isso, buscamos em nosso corpus os discursos que constituem tanto seu papel regulatório e decisor quanto o simulacro de soberania em relação a interesses de outras naçõesestado.

Sabemos que, em momentos de conflitos internacionais, a ONU funciona como uma espécie de juiz que avalia a situação e prepara uma série de ações que objetivem a resolução deles. Essa avaliação se dá por meio do Conselho de Segurança, composto por quinze membros, dentre os quais cinco têm direito a veto, ou seja, qualquer decisão deve ser sancionada pelo grupo e não conter o veto de nenhum desses cinco. Os representantes que possuem direito ao veto são Estados Unidos, Reino Unido, França, Rússia e China. Esse conselho é o único órgão competente para estabelecer decisões que, obrigatoriamente, devem ser seguidas por todos os Estados-membros. Lembramos que a Síria é membro da ONU desde 1945 e foi apenas três vezes membro do comitê de Segurança; 1947-1948, 19701971 e 2002-2003. A título de comparação, o Brasil foi membro dez vezes. Segundo o site da $\mathrm{ONU}^{10}$, as principais funções do Conselho de Segurança são:

- Manter a paz e a segurança internacional;

- Determinar a criação, continuação e encerramento das Missões de Paz, de acordo com os Capítulos VI, VII e VIII da Carta;

- Investigar toda situação que possa se transformar em conflito internacional;

- Recomendar métodos de diálogo entre os países;

- Elaborar planos de regulamentação de armamentos;

- Determinar a existência de ameaça contra a paz;

- Solicitar aos países que apliquem sanções econômicas e outras medidas para impedir ou deter alguma agressão;

- Recomendar o ingresso de novos membros na ONU;

- Recomendar para a Assembleia Geral a eleição de um novo Secretário-Geral.

\footnotetext{
${ }^{10} \mathrm{https}$ ://nacoesunidas.org/conheca/como-funciona/conselho-de-seguranca/
} 
Devemos retroceder, na análise de nosso corpus, ao inicio do conflito para obtermos um panorama do posicionamento discursivo da ONU, segundo relatos do jornal. Para isso, selecionamos excertos de um artigo de 08/06/2011, com o título de New Move to Condemn Syria in U.N., que nos traz o panorama das ações e dos posicionamentos dos países no conselho.

5.8

UNITED NATIONS - Britain and France circulated a revised draft resolution at the United Nations Security Council on Wednesday that would condemn the Syrian government for using force against its own civilians, but would scrupulously avoid a call for military action or any sanctions against the Syrian government.

5.9

China and Russia, both veto-wielding permanent members of the 15-member Security Council, have been resistant to support even a media statement condemning Syria, fearing that it could be a prelude to a similarly aggressive intervention.

5.10

Vitaly Churkin, the Russian ambassador to the United Nations, said Wednesday that Russia did not support a resolution on Syria. "We are not persuaded it can help establish dialogue and reach a political settlement," he said. "We're concerned it will have the opposite effect."

United Nations diplomats said Russia, a powerful ally of Syria, was using the situation in Libya as a justification to oppose action in Syria, arguing that NATO's risky intervention in Libya, under a United Nations mandate to protect civilians, had gone too far and risked becoming a protracted stalemate.

5.11

Voicing American support for a resolution condemning the violence used by the Syrian government against its own people, Susan E. Rice, the United States ambassador to the United Nations, said Wednesday that some countries on the Security Council were disingenuously using Libya as a pretext not to pass a resolution on Syria. "We will be on the right side of history," she said.

French and British diplomats said Wednesday that they had revised the language of the original resolution with the aim of making it politically untenable for Russia or China to block it. 
O primeiro parágrafo da reportagem (excerto 5.8) constrói a narrativa das ações do Conselho de Segurança. Como em qualquer Estado-nação, uma proposta deve ir à votação sob a forma de projeto, ou seja, de um documento que estabeleça o curso das ações e os posicionamentos da instituição. Em nosso texto, um documento foi preparado, em uma versão já revisada, pela França e pelo Reino Unido que condenavam as ações do governo Bashar, sem fornecer detalhes de seu teor. Encontramos apenas a descrição genérica "that would condemn the Syrian government for using force against its own civilians" e a afirmação "scrupulously avoid a call for military action or any sanctions against the Syrian government". Perguntamonos se o documento em questão seria apenas uma espécie de posicionamento oficial da instituição, sem intenção de estabelecer ações, pois, segundo a descrição, seria uma espécie de nota de repúdio sem qualquer objetivo de ações maiores, como vemos no segundo trecho.

Se entendemos o documento como uma espécie de nota de repúdio, podemos associá-lo a uma estratégia de marketing da instituição com o fito de provocar um efeito social na mídia, isto é, uma espécie de "agenda setting" que, ao se propagar pela mídia, estaria presente nas questões discutidas pela opinião pública, estabelecendo temas e interesses do público. Consideramos esse movimento como uma espécie de incentivo discursivo que objetiva estabelecer um discurso sobre a guerra e sobre o governo Bashar, embasado nos princípios ideológicos de seus idealizadores. Em outras palavras, levantamos a hipótese de o documento buscar o estabelecimento na opinião pública de uma posição discursiva que condena o governo Bashar e prepara a opinião para futuras deliberações que não feririam a imagem pacífica e justa da instituição e de seus elaboradores.

O excerto 5.9 fundamenta nossa percepção ao colocar dois países com histórico democrático discutível contra a proposta da França e do Reino Unido. A ideia ganha ainda mais força no momento em que o artigo cita textualmente o medo da China e da Rússia em declarar publicamente uma condenação do governo sírio. $O$ trecho "have been resistant to support even a media statement condemning Syria" parece até um pouco contraditório, já que todo o teor do artigo e dos valores dos países que elaboraram o documento é o de condenação. Entretanto entendemos que essa contradição tem como função estabelecer não uma dúvida no conselho de segurança, mas sim constituir um Eu e um Outro, numa oposição entre o lado certo e o errado da história. Esse nosso entendimento será demonstrado por intermédio do 
último trecho escolhido, onde surgem as seguintes palavras da embaixatriz americana na ONU: "We will be on the right side of history.".

Logo após a apresentação da opinião da Rússia e da China, o texto (5.10) expressa as palavras do embaixador Russo, dizendo-se não estar convencido de que uma resolução, tal como a proposta, ajude a atingir algo satisfatório, além de estar temeroso de até mesmo um efeito contrário. Em seguida, o texto faz questão de afirmar que a Rússia sempre foi um forte aliado Sírio, questionando a imparcialidade do embaixador e, consequentemente derrubando a credibilidade dele. Imaginamos que um leitor do artigo imediatamente se colocaria ao lado da resolução e repudiaria a atitude Russa.

Por fim, em 5.11, o texto afirma que o documento passou por uma revisão de linguagem - "revised the language of the original resolution with the aim of making it politically untenable for Russia or China to block it." -, que impossibilitaria os vetos russo e chinês. Novamente, não há menção ao teor do texto e muito menos à revisão feita. Sobre essa última, levantamos o questionamento sobre que tipo de revisão linguística do texto seria essa capaz de atribuir tal poder ao texto. A nosso ver nenhum texto está isento de interpretações nem consegue ser argumentativamente tão perfeito que não possa ser contradito. Percebemos que negar posições contrárias ao documento é apenas uma estratégia para a construção de um consenso sobre a condenação do governo sírio, isto é, uma estratégia que busca estabelecer um préconstruído para, futuramente, ser usado no julgamento das ações contrárias da Rússia e China.

Voltando à questão da soberania da ONU, nossas discussões já apresentadas neste trabalho permitem-nos perceber que a instituição vai trilhando um caminho de consensos, sejam eles entre as nações, sejam entre a instituição e a opinião pública. Essa fabricação de consensos viabiliza que a instituição se coloque num papel internacionalmente soberano para garantir uma aparente neutralidade na resolução de conflitos. O próprio funcionamento das Nações Unidas e, consequentemente, de seu Conselho de Segurança se assemelha ao funcionamento de um Estado democrático onde tudo é aprovado por meio de projetos, votações, discussões, reescritas de projetos, novas votações e novas discussões entre os diversos atores políticos que compõem o todo. Essa primeira análise trouxe alguns elementos que apontaram como se estruturam alguns dos discursos produzidos pela instituição e como esses são veiculados pela mídia. 
Focalizemos, nesse momento, não a operacionalidade do discurso, mas sim seu conteúdo. Para tanto, selecionamos alguns excertos de um artigo do jornal intitulado "U.N. Resolution on Syria Blocked by Russia and China" e publicado em 04/10/2011.

Contextualizemos o artigo em questão. O Conselho de Segurança da ONU cria um documento que condena e estabelece sanções ao governo sírio, como tentativa de pressão para acabar com a onda de massacres a civis. $O$ documento obteve nove votos favoráveis, quatro abstenções e dois contrários de países que têm direito a veto. Por isso o documento não foi aprovado. O texto então procura discutir as posições a favor e contra sendo, evidentemente, a favor do documento. $\mathrm{Na}$ argumentação, o texto expõe as justificativas dos dois lados, resumidas no quadro abaixo:

5.12

\begin{tabular}{|c|c|}
\hline Favorável & Contrário \\
\hline support a move toward democracy & $\begin{array}{l}\text { Security Council's resolution on } \\
\text { Libya had been twisted to encompass a NATO } \\
\text { war against the Libyan government and } \\
\text { saying they were determined not to repeat } \\
\text { that. }\end{array}$ \\
\hline $\begin{array}{l}\text { which nations have chosen to ignore } \\
\text { their calls for democracy and instead prop up } \\
\text { desperate, cruel dictators }\end{array}$ & $\begin{array}{l}\text { Western powers were using } \\
\text { humanitarian issues as a pretext to try to } \\
\text { weaken Syria and allow Israeli hegemony in } \\
\text { the Middle East. }\end{array}$ \\
\hline $\begin{array}{l}\text { "grave and systematic" human } \\
\text { rights violations }\end{array}$ & $\begin{array}{l}\text { against the peaceful solution of the } \\
\text { crisis on the basis of a Syrian national } \\
\text { dialogue }\end{array}$ \\
\hline want to continue to sell arms to Syria & $\begin{array}{l}\text { might increase violence there, } \\
\text { particularly because many Syrians do not } \\
\text { support the antigovernment movement. }\end{array}$ \\
\hline $\begin{array}{l}\text { "arbitrary executions, excessive use } \\
\text { of force and the killing and persecution of } \\
\text { protesters." }\end{array}$ & \\
\hline
\end{tabular}


should be granted fundamental

human rights, including freedom of expression

Ao dividir os argumentos lançados pelo texto, observamos uma distinta orientação ideológica. Os argumentos favoráveis baseiam-se, integralmente, nos princípios gerais da Declaração dos Direitos Humanos, materializados nas expressões do tipo democracy, rights violation, persecution e freedom. Todas essas palavras fazem parte daquele sistema semântico ao qual já nos referimos e reiteram os princípios ocidentais delineadores do discurso das Nações Unidas.

Também os argumentos contrários apontam exatamente para o mesmo lugar, com a diferença de que afirmam existir interesses políticos encobertos por um discurso humanitário. Também apontam para o fato de que qualquer sanção externa pode influir negativamente já que não promoveria o diálogo nacional, nem respeitaria parte da população que não apoia os movimentos.

Também notamos que, em nenhum momento, o lado contrário se opõe às questões humanitárias, nem sequer desmente os abusos do governo sírio. A preocupação não está em questionar a veracidade da violação dos direitos humanos nem sequer os próprios direitos, mas sim naquilo que subjaz a sua evocação. Dentro de um pensamento contemporâneo não seria possível questionar os princípios contidos na declaração: nenhuma nação, nenhuma entidade, nenhum cidadão seria capaz de dizer, sem ser apedrejado por seus pares, que o conteúdo da Declaração está equivocado.

A Declaração dos Direitos Humanos torna-se inquestionável. O que é possível, como vimos no quadro acima, é evocá-la ou questionar os interesses que subjazem ao seu uso. Dessa forma, o documento ganha um caráter soberano, assim como a instituição que o elaborou e o administra.

Abaixo, os dois excertos finais do artigo (5.13 e 5.14) deixam claro que o teor das questões humanitárias não está sendo discutido, mas sim os interesses específicos das Nações-estados membros do conselho.

5.13

The resolution on Libya approved by the Council in the spring was intended to protect civilians, Mr. Churkin said. But he contended that it was used instead as an excuse to 
fuel a civil war, with the North Atlantic Treaty Organization bombing civilian targets like television stations and oil facilities. The Chinese ambassador echoed those sentiments.

5.14

Ms. Rice, the American envoy, described the United States as "outraged" by the failure of the Council to pass the resolution. She dismissed the comparison to the Council's resolution on Libya as a "cheap ruse" by countries that want to continue to sell arms to Syria, and she derided the idea that the Syrian government just needed more time to carry out reforms.

O excerto 5.13 expõe, nos argumentos do embaixador russo, a posição dos contrários à resolução do Conselho de Segurança e faz referência a um documento anterior ao Conselho o qual tinha por objetivo conter a violência na Líbia. A estrutura sintática usada pelo texto anuncia um plano não realizado e que, em seguida, sofre um desvio, conforme se verifica nas seguintes sequências: "was intended to protect civilians" e "was used instead as an excuse to fuel a civil war". Em seguida, o texto faz um ataque afirmando que o documento beneficiou a NATO (North Atlantic Treaty Organization), ou OTAN, que, sendo uma instituição intergovernamental, é constituída em sua maioria por membros da Europa e da América do Norte. Seu principal objetivo é a defesa mútua dos países membros, quando atacados por outras forças externas.

No excerto 5.14, o posicionamento é dos que são a favor da resolução do Conselho de Segurança. O que observamos é a mesma forma de ataque, que, desta vez, adquire materialidade na expressão " 'cheap ruse' by countries that want to continue to sell arms to Syria". Anteriormente, o texto já havia citado o interesse dos BRICs. Dessa vez, a instituição então formada por Brasil, Rússia, Índia e China e que objetiva a cooperação econômica e política é acusada de ter interesses econômicos no fomento da guerra. Os países do BRIC são aqueles que se abstiveram de votar, ou vetaram o documento. A afirmação da enviada americana procura, então, responder por meio do mesmo tipo de argumentação usado pelo russo Mr. Churkin, para defender seu ponto de vista.

Pela análise dos dois excertos (5.13 e 5.14), observamos que nenhum dos dois lados questiona as questões humanitárias na Síria, nem mesmo as mortes, os massacres, as prisões e as violências. Muito pelo contrário, a realidade síria parece transformar-se em mero pano de fundo para questões de interesses e ataques de blocos econômicos e políticos. O que ressaltamos, observando também outras 
reportagens, é que em momento algum a questão da soberania da ONU e o teor ideológico daquilo que ela defende são questionados, pois colocar-se contra tal documento seria ir na contramão da ideia de desenvolvimento da própria humanidade, portanto seu valor legítimo, universal e supranacional é assegurado, assim como sua ideologia.

Arendt (1951, p. 428), na esteira de Burke (1790), afirma que

os direitos de que desfrutamos emanam "de dentro da nação", de modo que nem a lei natural, nem o mandamento divino, nem qualquer conceito de humanidade como o de "raça humana" de Robespierre, "a soberana da terra", são necessários como fonte da lei.

Portanto, não podemos compreender a Declaração dos Direitos Humanos como um mandamento divino, nem como uma lei natural, nem ainda como uma concepção de humanidade. Esses direitos surgem de um discurso que emana de dentro de uma nação e, como analisado, aderem a um projeto de origem americana.

\subsection{A expansão americana e a conflituosa relação com o Oriente}

Conforme mencionamos em capítulo teórico, sempre houve uma relação conflituosa entre os Estados Unidos e o mundo árabe. Said (1999) percebe que a nação americana nunca permitiu a independência desses países, pois isso poderia representar um entrave ao plano imperialista americano, ou enfraquecer seu maior aliado árabe, Israel.

A relação Estados-Unidos e mundo árabe se intensifica com o término da guerra fria. Os Estados Unidos, após a Segunda Guerra Mundial, e mais ativamente após o fim da Guerra Fria e o enfraquecimento do projeto socialista, se atribuem, com aval de outras nações, a responsabilidade de fiscalizar o mundo numa nova ordem e legislar sobre ele. Como explicitado anteriormente, Hardt e Negri (2001) afirmam que - País assume uma postura de polícia internacional capaz de garantir uma lei supranacional que garanta, assim, uma espécie de poder hegemônico.

Arendt (1951) afirma que não importa qual o tamanho dos conflitos no Oriente Médio, pois eles sempre atrairão a intervenção das superpotências. Aliás, segundo a 
autora, o que menos importa de fato são os conflitos, que parecem manipulados ou provocados por interesses que passam longe daquilo que está em jogo na região.

De acordo com Arendt (1951), Os Estados Unidos, por meio de sua política externa, assumem a responsabilidade de fazer guerra contra uma nação para proteger outras que nem são vizinhas dos EUA. A autora vê algumas dessas nações contra as quais os Estado Unidos promovem a guerra como meros degraus para a dominação, a extensão de riquezas e o acúmulo de poder.

A partir deste momento de nosso trabalho, colocamos em tela o projeto imperial americano e sua extensão pelo mundo árabe, esse último representado pela Síria. Comecemos por um artigo publicado no jornal em 19/09/2011 sob o título de "U.S. Is Quietly Getting Ready for Syria Without Assad".

Antes da análise propriamente do texto, gostaríamos de nos deter no título do artigo. Como se observa, o texto afirma haver um projeto de controle da Síria pelo governo americano e torna-se ainda mais sugestivo devido ao modificador "quietly". O uso desse advérbio pode gerar o entendimento de que a ação está sendo executada de modo secreto, sem explicar o motivo do segredo e sem precisar sua intencionalidade. Outra imprecisão da manchete é a expressão "getting ready", que pode significar uma infinidade de possibilidades e ser usada com verbos, como governar, administrar, tomar conta, partir, etc. Buscamos no texto alguma resposta ao que é proposto no título:

Increasingly convinced that President Bashar al-Assad of Syria will not be able to remain in power, the Obama administration has begun to make plans for American policy in the region after he exits.

Officials at the State Department have also been pressing Syria's opposition leaders to unite as they work to bring down the Assad government, and to build a new government.

5.16

That awareness is fueling the desire to plan for a post-Assad era, Obama administration officials say. "Nobody wants another Iraq," one administration official said on Saturday, speaking on the condition of anonymity. 
fear that the image of American intervention might do the Syrian opposition more harm than good.

O primeiro excerto (5.15) confirma os planos americanos para a região síria e faz referência à existência de uma "American policy in the region", em que "Policy" pode ser definido como um curso de ações ou de princípios adotados por um governo ou por uma empresa e implantados para um propósito e uma intencionalidade. "Policies" são guias de ações que buscam alcançar um resultado. Ao mencionar que há uma "policy in the region", o texto afirma a existência de um interesse americano na região, que pode ser associado com o que chamamos, neste texto, de projeto imperial americano.

O segundo e o terceiro excertos (5.16 e 5.17), assim como outras passagens do texto, expressam a preocupação com a saída do presidente Bashar. Como mencionamos em capítulo anterior, a Síria é composta por inúmeros grupos de etnias, de origens e de fundamentos religiosos diferentes entre si. Por esse motivo, a saída de Bashar poderia alavancar uma crise interna pela luta do poder entre os grupos, agravando ainda mais a situação e a estabilidade na região. Notamos que parte desse projeto americano é conter essa crise interna, havendo, para isso, o esforço do Departamento de Estado Americano em unir os diferentes grupos em prol de um novo governo. Isso nos remete um pouco à própria história de independência americana, segundo a qual 13 colônias, com objetivos e interesses diversos, unem-se para derrotar a Inglaterra e estabelecer um novo sistema político para o País, elaborando uma constituição genérica que garantisse a fundação de uma unidade democrática.

A intervenção americana deve ser bastante cautelosa, como informam os próximos dois excertos (5.17 e 5.18), pois poderia detonar uma crise interna que causaria mais mal do que bem aos grupos oposicionistas. O excerto (5.17) afirma a existência de uma espécie de medo da intervenção americana, "fear that the image of American intervention", o que poderia explicar o advérbio "quietly" usado no título. Mas considerando que nem o medo, nem a iminência de um conflito entre os opositores do governo Bashar interferem na elaboração da política americana para a região, a intervenção torna-se apenas mais cautelosa.

$\mathrm{Na}$ intenção de identificar que política poderia ser essa, resgatamos as ideias de Hardt e Negri (2001), discutidas anteriormente, sobre as características da 
soberania americana. Para tanto, observamos as três características apontadas pelos autores, a saber: a imanência do poder, a finitude/ponto de crise e o projeto expansionista aberto em espaço ilimitado. Vejamos os seguintes excertos $(5.17,5.18$, e 5.19) de um editorial publicado em 30/09/2011 sob o título "America's Man in Damascus".

5.17

Robert Ford, the United States ambassador in Damascus, is an exemplary and courageous diplomat. While President Bashar al-Assad of Syria and his henchmen have been slaughtering their people, Mr. Ford has been traveling the country, standing with the prodemocracy opposition and bearing witness to their sacrifice.

His actions are giving hope to Syrians, and clearly frightening the regime.

5.18

Mr. Ford has well proved the value of his presence, and Mr. Obama's wisdom in keeping him there. A seasoned diplomat and Arabic speaker, Mr. Ford has a reputation for getting to know the people of the country where he serves, not just attending embassy parties and official meetings.

5.19

In Syria, he has gone to funerals of murdered protesters and chatted with Syrians of all views on Facebook and Twitter. His knowledge and analysis of what is happening on the ground is essential at a time when Washington is rallying international condemnation of Mr. Assad's brutality and weighing what further steps to take.

O primeiro excerto (5.17) apresenta o embaixador americano em Damasco e sua posição fundamental de conciliador de conflitos. O texto ressalta suas qualidades, "exemplary and courageous", numa clara associação a um soldado na frente de batalha, no exercício da paz. O parágrafo introduz uma oposição, indicada pelo conectivo "while", entre a postura do diplomata e a do presidente Bashar: o primeiro dialoga com todos os oposicionistas enquanto o segundo mata violentamente seus próprios cidadãos. Ao final do excerto, afirma-se a postura política do embaixador, ao lado dos oposicionistas pró-democráticos, servindo como testemunha do sacrifício do povo.

A presença do embaixador acena para a legitimidade externa da causa defendida pelos oposicionistas: alguém que testemunha o sacrifício de um povo para 
se libertar de um regime absoluto com vistas à democracia e à liberdade. Como num movimento pela independência, o fato deve ganhar características heroicas, e o uso das expressões "courageous", "sacrifice" e "hope" reforçam essa ideia.

Retomando o que foi mencionado no capítulo 2, Hardt e Negri (2001) defendem que o primeiro momento para o desenvolvimento da soberania americana surge entre a independência e a guerra civil. No período pós-independência, o País é visto como um espaço aberto de construção coletiva, livre de domínios coloniais. Analogamente, o discurso do jornal tem muitas afinidades com as ideias de independência; nesse sentido, Bashar representaria a Inglaterra, e os rebeldes, os americanos que ansiavam pela democracia e pela liberdade.

Mais adiante, no excerto 5.18, o artigo aproxima a identidade do embaixador à dos sírios, afirmando que, além de conhecer a língua, o embaixador possui a reputação de conhecer muito bem o povo do país a que serve. Interessante observar que o texto deposita no conhecimento linguístico a questão da aproximação com a cultura, pois, ao falar árabe, o embaixador torna-se um pouco mais árabe. Outro detalhe observado é o uso do verbo "serve", que reforça a ideia anterior de um soldado americano.

Por fim, o ultimo excerto (5.19) complementa nossas considerações analíticas. Ao afirmar que o embaixador "chatted with Syrians of all views on Facebook and Twitter", o papel de conciliador fica delineado. É que o texto constrói a imagem de um lugar em conflito contra seu governo, mas que possui a pluralidade de visões sobre o fato. Mencionada anteriormente, essa multiplicidade do País pode, eventualmente, se transformar em um problema que possivelmente se materialize em ingovernabilidade na eventual saída de Bashar, colocando o país em outra guerra.

Com base em nossa memória discursiva, resgatamos as características de uma figura histórica e emblemática da história americana: George Washington. Comandante da guerra pela independência americana, presidiu o grupo que elaborou a constituição e foi nomeado o primeiro presidente da nação. Como presidente, adotou um tom conciliatório, fazendo cessar as revoltas, unindo grupos rivais e obtendo aceitação de todos os americanos. Muitas são as similaridades entre a imagem desse ex-presidente e a imagem criada do embaixador Ford. A presença de uma figura heroica, de um soldado da nação, de nobres ideais e de conciliador acompanha a formação da Nação americana desde sua formação e é repetida ao longo da história do País, ao abranger grandes personalidades, como George Washington e Barack 
Obama, ou pequenas e não tão populares personalidades, como a do embaixador Robert Ford.

Todas essas figuras trazem em comum a ideia de imanência de um poder que vem de um corpo social e tem nesse seu único objetivo, um conceito de que ele é seu princípio e seu fim. Karnal (2001) afirma que a constituição americana começa invocando o povo e falando de seus direitos numa clara acepção de que o povo é o princípio e o fim daquilo que se constitui como poder. Também, a ideia de que uma pluralidade pode se tornar um único país está presente no lema criado na fundação dos Estados Unidos. Karnal (2001) afirma que "E pluribus unum" (de muitos um) representa um país unificado, nascido de várias colônias. O autor sustenta que, apesar de todas as limitações do movimento de independência americana, esse movimento significa um fato histórico novo, promulgando a soberania do povo, como modo de derrubar formas de governo e romper a ligação entre governante e governado quando os cidadãos não tivessem seu direito garantido.

Notamos o funcionamento discursivo de caráter duplo e contraditório. Ao mesmo tempo em que a ideia de a imanência do poder dar a qualquer povo uma suposta construção de soberania, atribuindo a ele o governo sobre si mesmo, ela constitui uma base ideológica de origem americana, territorializando, dessa forma, seus princípios ideológicos e promovendo sua expansão.

Analisamos agora um segundo conceito, levantado por Hardt e Negri (2001): o de finitude e do caráter conflituoso da multidão. Relembramos que os autores (2001) concebem que a ideia de liberdade soberana gerada no primeiro momento da pósindependência torna-se contraditória durante a Guerra Civil. A escravidão, parte da organização social americana, se torna um entrave à soberania da liberdade e à formação de um povo livre. A expansão de um projeto americano de liberdade não poderia ser concretizada enquanto o país não pudesse resolver internamente seus conflitos. Pela segunda vez, no governo Lincoln, com o fim da escravidão, o país se reinventa, criando hipoteticamente uma nação de homens com direitos iguais perante a lei. A figura de Lincoln é mais uma dessas imagens heroicas de homens exemplares e corajosos iguais à construída pelo jornal do diplomata americano Robert Ford.

Sem dúvida, encontramos em nosso corpus inúmeros exemplos de contradições internas na Síria, visto que o País, como já afirmamos diversas vezes, possui diversidade étnica e religiosa bastante grande. Não nos focamos nesse tipo de conflitos e contradições, mas elegemos como foco principal analisar não só as 
contradições do discurso americano, mas também de que maneira ele se reinventa, fazendo perpetuar as ideias principais de seu projeto nacional. Para isso, observamos o excerto abaixo, retirado de um artigo de opinião sob o título de Why we shouldn't attack Syria (Yet) e publicado em 02/02/2012

In the 63 years since the United Nations adopted a genocide convention in the wake of the Holocaust, world leaders have failed to prevent the deaths of millions, from Biafra and Cambodia to Rwanda and Darfur - not just because they have lacked the political will to intervene, but also because of the norm of genocide itself. By setting the bar for intervention so high - unmistakable evidence of clear intent to destroy a national, ethnic, racial or religious group - the international community has stuck itself in a Catch-22: by the time it is clear that genocide is occurring, it is often too late to stop it.

5.21

For weeks, the United States and other nations appeared paralyzed, unclear whether Colonel Qaddafi's brutality would reach the level of genocide,

But rather than seeking regime change to prevent genocide, President Obama focused on the narrower objective of preventing "a humanitarian catastrophe" and explicitly ruled out foreign-imposed regime change.

5.22

These more modest, pragmatic goals sidestepped Mr. Gates's objections and reflect the emerging new standard for humanitarian intervention. The United States took the lead, but initially only to halt the mass-homicide campaign. And it rightly set goals that would not require an ambitious military commitment.

5.23

In the past few decades, the United States and other countries have successfully intervened for humanitarian purposes on three other occasions - in 1991, to stop Saddam Hussein's attempted massacre of the Kurds in northern Iraq after the gulf war, and to protect first Bosnians, in 1993, and then Kosovars, in 1999, from the Serbs' attempts at ethnic cleansing. All three humanitarian interventions occurred after thousands of people had been killed and exponentially more people had been injured or displaced. And all three were successful and saved thousands of lives. 
None of these cases, nor the war in Libya, amounted to true genocide, where hundreds of thousands were already dead at the time of intervention. Most important, none could become a genocide because intervention stopped the killing at an earlier stage.

5.25

Limited military force to stop campaigns of state-sanctioned homicide is more pragmatic than waiting for irrefutable evidence of "genocide."

5.26

As the world's sole military superpower, the United States will be at the center of many future debates over humanitarian action. Rather than hewing to the old standard of intervening only after genocide has been proved, the emerging new standard would allow for meaningful and low-risk military action before the killing gets out of control.

Observa-se, logo no título, que o uso do advérbio "yet", no final da frase, apoia um ataque à Síria, mas no tempo certo, isto é, o texto assume e endossa o ataque, bastando apenas esperar a hora certa. A justificativa para qual seria a hora certa vem no final do texto, em que se afirma ser necessário que as forças rebeldes, apoiadas pelos americanos, estejam isoladas e sob controle de algumas cidades para que o ataque possa evitar a morte de civis. A primeira tese que o texto sustenta é que o ataque é necessário. Em seguida, analisamos a argumentação desenvolvida para justificar esse ataque.

Basicamente o texto opõe homicídio e genocídio. Em 1948, o Conselho Geral das Nações Unidas adota a "Convenção para a Prevenção e Repressão do Crime de Genocídio" na qual genocídio é definido como "atos cometidos com a intensão de destruir, no todo ou em parte, um grupo nacional, étnico, racial ou religioso". Sobre o genocídio e o papel da ONU, o excerto afirma que, desde de sua criação, "world leaders have failed to prevent the deaths of millions", pois em cada situação, além da vontade política dos países, deve ser julgado se a guerra ou o conflito que está matando milhares de pessoas é ou não um caso de genocídio. Segundo o artigo, enquanto se perde tempo julgando se a guerra ou o conflito é um caso de genocídio, o que provavelmente começou como homicídio vai se tornando genocídio, matando milhares de pessoas.

Quando o texto, no excerto 5.20, declara que a comunidade internacional "has stuck itself in a Catch-22:", ele faz alusão ao romance histórico de Heller (1961), que 
se tornou uma expressão usada para referir-se a uma situação sem saída, uma espécie de armadilha. Talvez essa expressão determine o que sugerimos anteriormente como o conflito e a reinvenção do discurso americano face à contradição inerente de sua composição discursiva. Para compreender essa contradição, relembremos que tanto as Nações Unidas como a própria Declaração dos Direitos Humanos dialogam de maneira bem próxima com esse projeto americano. Assim, uma nação membro do conselho mundial deve julgar, condenar e tomar medidas cabíveis para que as leis internacionais sejam cumpridas. E é exatamente nessa posição que tanto Estados Unidos como outros membros aliados acabam vivenciando a contradição do processo.

O excerto 5.21 expõe a inabilidade dos Estados Unidos em lidar com esse processo, ao declarar que "the United States and other nations appeared paralyzed". Nesse aspecto, o texto faz clara referência ao levante popular na Líbia, avaliando os desempenhos americano e internacional e tentando estabelecer paralelos com a Síria. Ao afirmar que os países estavam paralisados, o texto assume a incapacidade de se exercerem as funções de polícia mundial dadas pelos princípios das convenções. Nesse caso, ou há uma espécie de erro na lei, ou uma inabilidade de gerenciar a lei.

De nossa parte, interpretamos não haver um erro, mas sim uma contradição inseparável do discurso promovido por esse modelo. É que, ao julgar se liberdades estão sendo violadas e ao defendê-las por meio de uma intervenção militar, o modelo coloca-se contra o próprio princípio de soberania e liberdade de uma nação. John Locke $^{11}$, em sua teoria sobre estado de base contratual, já aponta a contradição dizendo que todos os direitos de um governo cessam, caso ele use a força sem direito por se colocar em guerra contra os quais a emprega. A contradição se engendra garantindo o direito de um e limitando o direito do outro. A questão do genocídio, discutida anteriormente, é um exemplo claro, segundo o qual uma situação limítrofe é a única forma legal de suspensão de direitos. Outros exemplos na história americana, e discutidos anteriormente, tais como, a escravidão, a guerra civil americana e os conflitos de classe, são as contradições desse projeto que deve em todo o tempo se reinventar.

\footnotetext{
${ }^{11}$ LOCKE, John. Segundo tratado sobre o governo (1689).
} 
Em seguida, o mesmo excerto (5.20) e os seguintes (5.21- 5.26) passam a descrever, nas ações tomadas contra a Líbia pelo presidente Obama o que entendemos como essa reinvenção.

\begin{tabular}{|l|}
\hline CONSTITUIÇÃO DO NOVO PADRÃO \\
President Obama focused on the narrower objective of preventing "a \\
humanitarian catastrophe \\
These more modest, pragmatic goals sidestepped Mr. Gates's objections \\
and reflect the emerging new standard for humanitarian intervention \\
the emerging new standard would allow for meaningful and low-risk military \\
action before the killing gets out of control. \\
\hline ADEQUAÇÃO AOS DISCURSOS DA ONU \\
And it rightly set goals that would not require an ambitious military \\
commitment. \\
\hline Limited military force to stop campaigns of state-sanctioned homicide is \\
more pragmatic than waiting for irrefutable evidence of "genocide." \\
\hline ADEQUAÇÃO AO DISCURSO DE UM PROJETO NACIONAL \\
\hline The United States took the lead, but initially only to halt the mass-homicide \\
campaign. \\
\hline All three humanitarian interventions occurred after thousands of people had \\
been killed and exponentially more people had been injured or displaced. And all \\
three were successful and saved thousands of lives.
\end{tabular}

Todo o texto concentra-se em elencar quais são essas mudanças, ou seja, essa reinvenção da "lei". Dividimos os trechos em blocos, agrupando-os por funções. O primeiro descreve o novo padrão de ação e se contrapõe ao antigo em termos de objetivo, afirmando que, ao não pensar grande (genocídio), uma abordagem mais restrita pode impedir uma catástrofe. O segundo legitimiza o novo padrão, adequandoo ao papel das Nações Unidas e sugerindo que as ações militares seriam modestas e limitadas, caso fujam de uma deflagração de guerra. O último adere o novo projeto ao discurso nacional americano, afirmando o status de liderança do país e seu caráter humanitário, ao salvar a vida de milhares de pessoas e, assim, garantir o direito à vida e à liberdade contido no discurso nacional.

Dessa forma, o projeto de expansão americano é forçado a se reinventar para que os princípios que o formam possam se expandir de forma a englobar o conflito 
que emana da multidão. A multidão, nesse momento, pode ser compreendida externamente como o próprio cenário internacional, onde interesses regionais se sobrepõem e, por isso, geram colisões de caráter político e ideológico.

Por fim, gostaríamos de analisar a terceira característica proposta por Hardt e Negri (2001). Os autores afirmam que é característica da soberania americana a ideia de que essa soberania, operando em espaço aberto e ilimitado, não busca destruir o outro, mas sim incorporá-lo em seus domínios, constituindo o que os autores chamam de "república universal". Já exploramos esse tópico quando analisamos o discurso dos documentos das Nações Unidas e de seus desdobramentos no discurso da mídia: reconhecemos muito do discurso que orienta os Estados Unidos desde sua formação. Cabe apenas uma rápida passagem pelo discurso americano em si, e não na presença dele nas entrelinhas que formam o discurso institucional da ONU

Para tanto, analisamos um artigo que expõe com clareza a expressão americana. Selecionamos, para isso, alguns excertos da transcrição, feita pelo jornal, de um discurso do ex-presidente Barack Obama publicado no dia 19/05/2011:

For six months, we have witnessed an extraordinary change taking place in the Middle East and North Africa. Square by square, town by town, country by country, the people have risen up to demand their basic human rights

5.28

That story of self-determination began six months ago in Tunisia. On December 17th, a young vendor named Mohammed Bouazizi was devastated when a police officer confiscated his cart. This was not unique. It's the same kind of humiliation that takes place every day in many parts of the world -- the relentless tyranny of governments that deny their citizens dignity.

There are times in the course of history when the actions of ordinary citizens spark movements for change because they speak to a longing for freedom that has been building up for years. In America, think of the defiance of those patriots in Boston who refused to pay taxes to a King, or the dignity of Rosa Parks as she sat courageously in her seat.

5.29

a citizen like that young vendor had nowhere to turn - no honest judiciary to hear his case; no independent media to give him voice; no credible political party to represent his views; no free and fair election where he could choose his leader. 
But in a global economy based on knowledge, based on innovation, no development strategy can be based solely upon what comes out of the ground. Nor can people reach their potential when you cannot start a business without paying a bribe.

5.31

But the United States of America was founded on the belief that people should govern themselves. And now we cannot hesitate to stand squarely on the side of those who are reaching for their rights, knowing that their success will bring about a world that is more peaceful, more stable, and more just.

O primeiro excerto (5.27) exalta positivamente os acontecimentos recentes, por meio do uso da expressão "extraordinary change". Embora diante de conflitos, muitas vezes fatais, o discurso de Obama é positivo, pois enaltece o aspecto ideológico das revoltas. O dito aqui se constrói a partir do não-dito, pois a segunda possibilidade seria dizer que o Oriente Médio passa por um conflito sangrento que resulta na morte de várias pessoas. Ao fazer sobressair o aspecto positivo, Obama enfatiza o caráter ideológico e político das revoltas e abre sua fala aproximando as revoltas às ideologias compartilhadas pelos americanos; o ex-presidente não separa um Eles de um Nós, mas coloca todos num mesmo local ideológico. Tanto nesse trecho, como no que veremos a seguir, o discurso de Obama é inclusivo, tornando o Oriente mais próximo daquilo que o Ocidente possui.

Nos excertos de 5.28 a 5.30 , o presidente, ao afirmar o que o povo de países do Oriente Médio e do Norte da África não têm, faz uma inferência que consolida o que os americanos têm, tornando-os uma espécie de objeto de desejo de todos. Esses objetos estão definidos, entre outras, nas seguintes expressões:

- Freedom,

- Dignity,

- Patriotism,

- Honest judiciary,

- Independente media,

- Credible political parties,

- Free and fair ellection,

- Knowledge and innovation, 
- Individual potential.

Nas palavras do então presidente, os valores acima apontados tornam-se valores desejados por todos os povos cujos direitos são, de alguma forma, suprimidos por tiranos e ditadores. Dessa forma, os valores e os objetos constitutivos da sociedade americana passam a ser valores de todos. Numa visão discursiva, o texto aponta que todos almejam possuir o que os americanos possuem, isto é, ser incluídos no mesmo projeto ideológico.

Cabe realçar a comparação feita pelo então presidente Barack Obama entre o ato heroico de Mohammed Bouazizi na Tunísia e os casos dos americanos de Boston que, na época da independência, se recusavam a pagar impostos à Inglaterra, ou o caso de Rosa Parks que, em Montgomery, em pleno momento de segregação racial, senta-se bravamente no lugar reservado aos brancos. Essas comparações igualam ideologicamente todos esses heróis, colocando-os dentro de um mesmo projeto.

No último excerto (5.31), observamos a questão inclusiva presente na ideologia expansionista americana. Barack Obama afirma esse projeto, primeiramentes ao referir-se a seu próprio país "the United States of America was founded on the belief that people should govern themselves" e, em seguida, ao defender a expansão da mesma crença "we cannot hesitate to stand squarely on the side of those who are reaching for their rights". Esse excerto não apenas confirma algumas das questões ideológicas e políticas descritas acima, tal como o governo do povo sobre si mesmo, como ainda vai mais além, ao certificar que o país defenderá sua expansão.

Cabe ressaltar que, quando falamos em expansionismo, estamos bem além de limites de fronteiras físicas, ou mesmo econômicas. Entendemos esse expansionismo no plano ideológico do discurso, ou seja, como a procura por expandir seus limites, transformando o mundo em um lugar habitado pelo mesmo discurso e, portanto, susceptível à dominação de um país com maior poder econômico. 


\section{3 - Oriente, o domínio do mal: os Rogue States e a fabricação do consenso ${ }^{12}$}

Analisamos, agora, como o texto trabalha na materialização de um discurso que subjuga o Oriente, construindo uma imagem negativa, ou seja, aquilo que Chomsky (1999) chama de Império do mal, ou "Rogue States". Árabes e muçulmanos são constantemente retratados como fundamentalistas e terroristas potenciais, sendo, pois, vítimas de uma caracterização negativa, como afirma Said (1997). Por representar uma agressão potencial, os "Rogue States" são vistos com uma hostilidade ideológica que ameaça o Ocidente e o Cristianismo.

Nas palavras do autor (1999), os Estados Unidos assumem a posição de protetores do mundo, devendo zelar pela paz mundial e combater o mal em todos os lugares. O juízo da existência do mal estabelece a dicotomia entre o eu e o outro e garante que as diferenças culturais e ideológicas possam ser estabelecidas, valorizando sempre os princípios daquele que tem a voz. O que me difere do outro são as crenças que eu assumo e consequentemente o quadro que faço do mundo. Ao contrapor dois mundos antagônicos, o discurso engendra uma verdade, há um certo e um errado, que se transforma em motivação de conflitos e de luta.

Mais recentemente, o medo do terrorismo e do fundamentalismo do mundo árabe foi difundido no mundo, imprimindo-lhes uma proporção gigante na Europa e nos Estados Unidos, principalmente após o 11 de setembro. Depois da queda do World Trade Center, um símbolo capitalista e dos ataques a Washington, os Estados Unidos decretaram guerra contra o terror, intensificando a associação do mundo árabe com o Império do mal. O terror construído pelo discurso americano chegou a tal ponto de provocar pânico na população simplesmente ao ver um homem de turbante, ou uma mulher de lenço na cabeça.

Segundo Bucci (2009) as verdades de nosso tempo são construídas pela imagem, e quando há um ataque à imagem também ferimos a verdade. $\mathrm{O}$ ataque à imagem do Império, como no 11 de setembro, fere as verdades engendradas no discurso americano e contrapõem, como dissemos antes, dois mundos, duas

\footnotetext{
${ }^{12} \mathrm{O}$ título faz referência ao conceito usado por Chomsky de Walter Lippman, explicitado no decorrer do capítulo.
} 
verdades, uma certa e outra errada. Ao estabelecer o eu e o outro, o discurso passa a construir a imagem do inimigo.

Sem dúvida, lemos, vemos e ouvimos todos os dias discursos que propagam a imagem do mundo árabe associada ao terror, ao fundamentalismo e ao extremismo. Inúmeros são os casos em que as matérias jornalísticas reportam negativamente os países árabes, principalmente aqueles que estão em conflito. Entretanto, a apropriação do discurso do terror pode aparecer em qualquer local, mesmo naqueles onde não esperamos, ou seja, na fala do próprio "terrorista". No dia 09/05/2011, encontramos o seguinte artigo jornalístico em que Ms. Shaaban, uma conselheira do governo Sírio, fornece a seguinte declaração:

5.32

MS. SHAABAN SAID, "WE THINK THESE PEOPLE ARE A COMBINATION OF FUNDAMENTALISTS, EXTREMISTS, SMUGGLERS, PEOPLE WHO ARE EX-CONVICTS AND ARE BEING USED TO MAKE TROUBLE."

Nessa declaração, a política síria classifica os rebeldes usando os adjetivos fundamentalistas, extremistas, contrabandistas e ex-condenados. Ao classificá-los dessa forma, ela está identificando os rebeldes como os inimigos do mundo ocidental e aderindo ao seu discurso.

Usando o conhecimento discursivo acima explicitado, totalmente alinhado com a crença americana, pode-se admitir que o governo sírio tenta se apropriar desse discurso e de desqualificar o movimento popular. Em outros artigos, pudemos perceber a mesma estratégia, principalmente dentro das Nações Unidas. Os portavozes do governo Sírio insistem em alinhar os rebeldes aos fundamentalistas e aos extremistas. Essa apropriação do discurso do medo americano traz ainda mais credibilidade à noção atribuída do bem contra o mal, colocando seus ideais como valores universais. O discurso do mal é sempre o discurso do outro, daquele que, ideologicamente, difere de mim e que, portanto, está contra a verdade. Ao se colocar contra a verdade, o outro assume a posição de inimigo e, consequentemente, deve ser aniquilado.

Apropriando-se do discurso Ocidental do terror, o governo sírio valoriza ainda mais as crenças americanas e reforça a ideia da existência de uma polícia mundial que deve interferir na defesa das verdades. Feito isso, não se questiona mais a 
existência do mal, que passa a ser dado como certo, assim como a verdade. O que cabe apenas é o juízo sobre qual é a origem do mal e nesse ponto troca-se apenas o sujeito que se adjetiva, e não a adjetivação.

Para finalizar, analisamos o conceito que Chomsky (1999) empresta de Walter Lippman, a chamada fabricação do consenso. Por ela, podemos entender um sentimento de concordância e consentimento que deriva de uma série de imagens geradas que chegam a um limite onde determinada situação não pode mais ser tolerada. Chomsky (1999) analisa dois pontos fundamentais responsáveis por esse sentimento. O primeiro é uma espécie de inação que não impede o estabelecimento do caos; e o segundo, o papel da mídia na veiculação de imagens negativas que contribuem para formação desse sentimento. Segundo o autor (1999), chega-se a um momento em que a situação não pode mais ser tolerada, o estado torna-se incapaz de contê-la e a multidão, como uma espécie de rebanho desgovernado, começa a se pisotear. Nesse momento, cabe a uma elite política assumir o controle e conter a multidão, evitando a catástrofe.

Encontramos, em nosso corpus, uma infinidade de exemplos, nos quais a inação dos organismos internacionais é descrita por, inclusive, americanos e dezenas de reportagens. São exemplos que descrevem e contabilizam estatisticamente a morte de civis pelas forças do governo.

Logo no início dos conflitos, no dia 27/03/2011, em dois excertos já mencionados no capítulo anterior, encontramos:

CAIRO -- Violence continued to plague Syria on Saturday, as government forces killed more demonstrators in Latakia, protesters burned offices of the ruling party in the south and west, and mourners throughout the country buried the dozens of unarmed protesters killed a day earlier.

President Bashar al-Assad of the ruling Baath Party began the day in what appeared to be a gesture intended to ease the crisis, when he announced the release of as many as 200 political prisoners. But by sunset, Baath Party offices were burning in at least two cities, the military was deployed in Latakia and once again government forces opened fire with live rounds, witnesses said. 
BEIRUT, Lebanon - The Syrian Army stormed the restive city of Dara'a with tanks and soldiers and helped detain dozens in towns across the country Monday in an escalation of the crackdown on Syria's five-week-old uprising, according to residents and human rights

No excerto 5.33, que já fornece estatísticas ao utilizar a palavra dúzias, observamos claramente que a morte de manifestantes é responsabilidade das forças do governo. Os manifestantes também são descritos como não armados, segundo a narrativa de grupos dos direitos humanos que também confirmam a morte de 61 pessoas. No excerto 5.34, publicado apenas um mês depois do excerto anterior, confirmamos a informação anterior: a morte e a prisão de manifestantes com o detalhamento, desumano, de corpos jogados nas ruas.

Há claramente uma progressão da narrativa e a reincidência das ações do governo sírio, afirmando, repetidamente e de forma cada vez mais enfática, a violação das leis da Declaração Universal dos Direitos Humanos. Alguns dias depois, em 05/05/2011 e em 09/05/2011, encontramos os seguintes textos:

5.35

AMNESTY INTERNATIONAL SAID MONDAY THAT MORE THAN 350 PEOPLE, INCLUDING 48 WOMEN AND A 10-YEAR-OLD CHILD, WERE ARRESTED THERE OVER THE PREVIOUS THREE DAYS

5.36

AMNESTY INTERNATIONAL SAID IT HAD DOCUMENTED THE NAMES OF 580 PEOPLE KILLED SINCE THE UPRISING BEGAN IN MID-MARCH.

SYRIAN SECURITY FORCES RAIDED A RESTIVE DAMASCUS SUBURB ON THURSDAY, GOING HOUSE TO HOUSE AND ARRESTING SCORES OF MEN IN A BROAD CAMPAIGN

AMNESTY INTERNATIONAL SAID THIS WEEK THAT DETAINEES WERE BEATEN WITH STICKS AND CABLES AND SOMETIMES DEPRIVED OF FOOD

Esses dois textos, também validados pela conceituada instituição, traçam o panorama cada vez mais cruel do que acontece na região. Como observamos, as mortes, antes apenas indicadas por números, passam a ser comprovadas por nomes. Os danos corporais são explicitados, no último excerto, como torturas e maus-tratos 
impostos aos prisioneiros. Todas essas ações já estavam presentes, mas que há, agora, uma mudança na descrição delas. Os dados passam a ser validados por um organismo internacional que atua na investigação de prisões políticas, torturas e execuções, cuidando exatamente da defesa dos direitos humanos.

Na progressão da narrativa, encontramos uma reportagem de 08/11/2011, após o presidente Bashar permitir a entrada da Liga Árabe no país, na qual se relatam as negociações de paz. Observe-se o seguinte excerto:

PRESIDENT BASHAR AL-ASSAD OF SyRIA HAS MADE A MOCKERY OF THE ARAB LEAGUE PEACE INITIATIVE. SinCE HE SIGNED THE DOCUMENT, HIS SECURITY FORCES HAVE MERCILESSLY ATTACKED THE CITY OF HOMS WITH HEAVY WEAPONS, HUNTED DOWN ARMY DEFECTORS AND KILLED SCORES OF PRO-DEMOCRACY PROTESTERS

Percebemos que os ataques aos manifestantes não acabaram, nem diminuíram. Nas expressões "mercilessly", "heavy weapons", "hunted down" percebemos o mesmo nível de massacre que já estava ocorrendo, sem nenhuma mudança de atitude. A narrativa é ainda intensificada quando o texto qualifica a postura de Assad, afirmando "President Bashar al-Assad of Syria has made a mockery of the Arab League peace initiative". Essa quebra do pacto, asúintensificações dos conflitos e o crescente numero de mortes podem indicar o início da situação de caos apontada anteriormente e fazer com que uma elite política tenha de agir de forma diferente, possivelmente por meio de um combate direto.

Um ponto a ser observado é que o então presidente Barack Obama sofreu críticas por não agir de modo mais assertivo nos conflitos. O excerto a seguir (5.38) traz explicitamente a intenção americana de não intervir militarmente na Síria, justificando que ninguém quereria uma nova guerra no Oriente Médio.

In seeking other ways to ensure that the Syrian government and its henchmen pay a price for slaughtering their citizens, United States officials are seeking ways to bring them to 
justice. A war crimes tribunal run by the Arab League could be the solution. The experience of war-torn countries like Bosnia has proved that such tribunals can work, if properly designed.

Last weekend, Secretary of State Hillary Rodham Clinton said that the United States would "support and train Syrian citizens working to document atrocities, identify perpetrators, and safeguard evidence for future investigations and prosecutions." A difficulty with this plan, however, is how to use the evidence that is collected. Syria is not a party to the treaty for the International Criminal Court in The Hague, and Russia and China would most likely use their veto power to block any United Nations Security Council effort to refer the case to the court.

A proposta trazida pelo governo americano, e retratada nesse artigo, seria a da criação de um tribunal que pudesse julgar e punir o governo Sírio. A Síria não faz parte do pacto de Hague, por isso a China e a Rússia fariam objeções de levar o caso à corte. Sugere-se, então, uma série de movimentos diplomáticos que buscam legalidade para as ações contra a Síria. É importante reconhecer que existe uma busca por legitimidade retratada por esse excerto, e por muitos outros do período compreendido nesta pesquisa. Em vários artigos, encontramos o governo americano muito caracterizado na pessoa de Barack Obama, buscando essa mesma licitude fora e dentro dos Estados Unidos.

Por legitimidade, compreendemos um estado de aquiescência, segundo o qual a instalação do caos daria abertura para uma política intervencionista mais efetiva. Todos os artigos aqui analisados apontam que há, em primeiro lugar, um debate e uma preocupação acerca da guerra da Síria e, ao mesmo tempo e justamente por se tratar de um debate sobre a legalidade de qualquer tipo de ação, uma paralisia que cada vez mais provoca o caos no pais.

Ressaltamos que essa análise feita por nós concretiza-se a partir do ano de 2013, quando, ao se aproveitar da desorganização dos grupos rebeldes e da inação de instituições internacionais, o grupo Estado Islâmico começa a participar ativamente na guerra, primeiro ao lado dos rebeldes e, a seguir, de maneira independente, em busca de hegemonia na região. ${ }^{13} \mathrm{E}$ é partir desse momento que os Estados Unidos e seus aliados começam a lutar ao lado dos rebeldes, e a Rússia, ao lado das forças de Assad, deflagrando efetiva participação internacional na guerra.

\footnotetext{
${ }^{13} \mathrm{O}$ período em questão encontra-se fora do escopo selecionado para essa pesquisa, portanto a menção tem caráter ilustrativo.
} 
Neste capítulo, demonstramos de que maneira o discurso de um projeto ideológico americano se alarga em âmbito internacional, primeiramente por meio dos discursos que constituem os mecanismos internacionais de controle da paz e da ordem mundial, e a seguir pela validação constante de um projeto que visa expandir sua própria ideia de soberania.

Naquilo que estamos chamando de projeto nacional americano está contida a ideia de expansão ideológica para além dos limites nacionais, fazendo uma clara separação entre o que é parte do modelo e o que não é. O Oriente, ao se confrontar com esse projeto, se diferencia e, portanto, afirma uma posição ideológica contrária.

O projeto de caráter inclusivo busca, em primeiro lugar, regular suas contradições internas reinventando-se; uma vez resolvida a contradição e fortalecida a ideologia, o discurso busca a sua expansão. Ao estabelecer verdades e valores, um corpo social passa a exigir das elites políticas ações que garantam e assegurem os princípios universais constituídos discursivamente, gerando, assim, seu caráter soberano, além de valorizar sua origem: os Estados Unidos. 


\section{CAPÍTULO 6: DO DISCURSO DA MÍDIA}

"In America the President reigns for four years, and Journalism governs forever and ever." Oscar Wilde (1891)

Neste capítulo, determinamos alguns sentidos do discurso da mídia no que se refere especificamente às questões de conflitos internacionais, para analisarmos a guerra na Síria. Retomando o conceito de valor das notícias, verificamos como a guerra se encaixa num esquema de valores advindos dos mapas de sentidos conceituais americanos. Em outras palavras, investigamos como a mídia torna o discurso sobre o evento da guerra inteligível e condizente com os valores da cultura americana. Em seguida, e acreditando ser a mídia uma das grandes responsáveis pelo poder simbólico, investigamos de que maneira ela se apoia em uma tradição, numa normatização desse poder, para a criação e a manutenção de um espírito público americano. A partir dessas análises, discutimos de que maneira o discurso da mídia retrata a guerra como um ataque que pode ferir a verdade da imagem americana e, a ao mesmo tempo, como um espaço que ajuda na reconstrução e ressignificação dessa mesma verdade.

\subsection{A inteligibilidade da guerra e os valores nacionais americanos}

Inteligibilidade, segundo o sentido dicionarizado, diz respeito àquilo que pode ser compreendido e apreendido sobre as coisas, sobre o mundo e sobre os outros. Fairclough (1992) afirma que um texto leva em conta uma série de pressupostos e expectativas que não estão no âmbito textual, mas na sua relação com aquele que recebe o texto. Assim, para que um texto seja coerente, além de estabelecer ligações textuais em si, ele se conecta às experiências do leitor, dialogando com ele. A essa série de saberes que já estão no intérprete, Fairclough (1992) nomeia de "member resources", assumindo que esses recursos são construídos nas expectativas e no 
senso comum. Nessa perspectiva, o autor acrescenta haver uma espécie de preenchimento automático das informações que o texto apenas deixa implícitas.

E é o leitor o responsável por fazer as conexões que o texto deixa em branco; em última análise, todo processo de fazer um texto ser coerente e significar não é uma propriedade do texto, mas sim do leitor.

Conforme o autor (1992), todas as premissas implícitas e o senso comum estão atrelados a uma ideologia que funciona serviço das estruturas de poder, evidentemente sustentando relações de desigualdades.

Tendo em vista esses pressupostos teóricos, investigamos como o texto do jornal The New York Times, em sua narrativa da guerra sobre a Síria, indica pressupostos então construídos na sociedade americana que fazem parte desse "member resources" que, em última instância, faz o texto ser inteligível para o leitor.

Buscando uma memória discursiva que resgate os recursos que o cidadão americano possui e que constitui um mapa conceitual da compreensão do mundo, exploramos, aquilo que Karnal (2001) chama de espírito de Macbeth. Esse conceito remonta ao período de independência e diz respeito à memória política inglesa segundo a qual o príncipe moderno, totalmente desvinculado da moral e da teologia, não leva em conta se suas ações são moralmente corretas. O objetivo único é conseguir poderes absolutos. Desvinculado de valores morais, o homem está livre da sina e do destino e livre da legitimidade do poder real.

Conforme Karnal (2001), o folheto de Paine, Senso Comum, em 1776, explora muito bem o conceito, tornando-se veículo de propaganda da independência americana e combatendo tanto o abuso da monarquia nas colônias americanas, quanto a própria monarquia como instituição. Esse documento será a base da declaração de independência americana, na qual encontramos 27 motivos que justificam a separação entre Estados Unidos e Inglaterra.

Por ser um documento nacional de grande poder simbólico que justificou a guerra contra a Inglaterra, selecionamos alguns dos motivos expressos na declaração a fim de observar se eles, de alguma forma, dialogam com a narrativa da guerra na Síria descrita pelo The New York Times, cumprindo assim a função de dar inteligibilidade ao conflito e à posição de apoio aos rebeldes defendida pelos americanos.

Editamos abaixo alguns trechos selecionados da Declaração de Independência Americana: 
He has erected a multitude of New Offices, and sent hither swarms of Officers to harass our people and eat out their substance.

He has kept among us, in times of peace, Standing Armies without the Consent of our legislatures.

He has affected to render the Military independent of and superior to the Civil Power.

$\mathrm{He}$ has combined with others to subject us to a jurisdiction foreign to our constitution, and unacknowledged by our laws; giving his Assent to their Acts of pretended Legislation:

For quartering large bodies of armed troops among us:

For protecting them, by a mock Trial from punishment for any Murders which they should commit on the Inhabitants of these States:

For depriving us in many cases, of the benefit of Trial by Jury:

(...)

He has plundered our seas, ravaged our coasts, burnt our towns, and destroyed the lives of our people.

He has excited domestic insurrections amongst us, and has endeavoured to bring on the inhabitants of our frontiers, the merciless Indian Savages whose known rule of warfare, is an undistinguished destruction of all ages, sexes and conditions.

$(\ldots)$

In every stage of these Oppressions We have Petitioned for Redress in the most humble terms: Our repeated Petitions have been answered only by repeated injury. A Prince, whose character is thus marked by every act which may define a Tyrant, is unfit to be the ruler of a free people.

Logo de início, desperta-nos a atenção a declaração citar a criação de inúmeros cargos preenchidos por funcionários que perseguiam o povo. Uma das características apontada anteriormente tanto na parte teórica, quanto em nossa análise do corpus foi a menção de que, na maioria das famílias sírias, havia sempre pelo menos um membro que trabalhava para o partido, pois essa seria uma forma de sobrevivência num país rigidamente governado pelo partido de Bashar. A declaração sugere que, além dos gastos, esses funcionários seriam uma forma de vigilância das regras impostas pela coroa britânica.

Lembramos que, historicamente, quando há um regime de poder absoluto, há o inchaço do partido que controla esse governo. Isso parece estar em consonância com o "espírito de Macbeth", de Karnal (2001). Construir a imagem de um partido único, inchado, por isso em constante vigilância, cujos membros se encontram em 
cada família da nação é construir a imagem de um regime absolutista e totalitário, como a Alemanha de Hitler, a União Soviética de Stalin ou a ficcional Oceania do Grande Irmão, em 1984, de George Orwell. Os excertos abaixo, de um artigo publicado em 05/02/2011, fazem as mesmas afirmações da declaração.

6.1

Syrian human rights activists said Thursday that Syrian government forces had killed more than 100 people in the rebellious city of Hama in the first 24 hours since seizing control of its central square with armored columns and snipers.

6.2

Telephone lines, cellphone and Internet service and electricity and water were cut off two days ago in Hama and have not been restored. Satellite connections offered perhaps the only route left to get information out. Activists said they feared that the near total media blackout on the city would allow the military to pursue an unrestrained assault.

6.3

"The authorities are using excessive force against unarmed peaceful demonstrators," said Mohammad Habash, a Syrian lawmaker in Damascus. "This military interference is unnecessary."

He said that he had heard from residents that in one neighborhood, Al-Alamayn, 30 people had died since Wednesday. Mr. Fadi said the information was hard to confirm because snipers loyal to the government were shooting at anything that moved.

$(\ldots)$

the sniper fire and that two women bled to death in front of him because they could not be safely taken to a hospital.

6.4

Mr. Hussein, himself a former prisoner, said that the government was believed to have turned public buildings into camps to accommodate the numbers of detainees.

6.5

"He needs to urgently carry out reforms, reconcile with the opposition, restore peace and set up a modern state," Mr. Medvedev said. "If he fails to do this, he will face a sad fate."

Nos excertos 6.1 e 6.2, observamos que o governo Sírio, por meio de forças militares, tomou o controle da cidade de Hamas e, ocupando a praça central com 
soldados e atiradores, matou 100 pessoas no ataque. Por esse relato, percebemos o uso do poder militar sírio contra o seu próprio povo, uma situação que é descrita na declaração de independência. Também vemos que os soldados e ou militares sírios são parte do povo sírio, por isso há uma espécie de insurreição interna, colocando o povo contra o próprio povo. Em um momento posterior, como descrito em um excerto do capítulo anterior, muitos militares abandonam seus cargos e juntam-se aos rebeldes por não concordar com lutar contra seu próprio povo.

Nos próximos excertos, observamos novamente o mesmo quadro descrito no parágrafo anterior. Nos trechos, "the near total media blackout on the city would allow the military to pursue an unrestrained assault." e "The authorities are using excessive force against unarmed peaceful demonstrators", identificamos tanto o uso das tropas militares, diga-se anteriormente mencionado -, quanto a questão da busca pelo poder absoluto, mesmo sem respeitar a vontade de povo e sem preocupar-se com a ordem moral - devido à morte de cidadãos sírios. O artigo menciona textualmente as palavras de um líder sírio rebelde: "This military interference is unnecessary." $\mathrm{Na}$ mesma fala, o líder afirma que as mortes na cidade incluíam crianças e mulheres, mesmo teor encontrado na declaração de que não há distinção de sexo, idade ou condição. A fala traz credibilidade à ideia de uso dos poderes militares de maneira independente e superior ao poder civil, assim como mencionado na declaração.

Relativamente ao excerto 6.4, de acordo com a declaração de um dos líderes dos rebeldes, muitos cidadãos são detidos e levados a prédios públicos, transformados em "camps". O narrador da fala, Mr. Hussein, foi um desses prisioneiros do governo. O trecho de Hussein, em discurso direto, corrobora com a ideia de que os detentos, além de muitos, são privados de julgamento ou recebem julgamento simulado. Diga-se que essa descrição está de acordo com a do documento americano.

No último excerto, que finaliza a reportagem, constatamos a posição do presidente Russo Medvedev, antes sempre aliado ao governo Bashar, admitindo que o sírio deveria se reconciliar com a oposição e preparar as reformas no País para o estabelecimento de um "modern state". Essa declaração está muito próxima do texto final da declaração de independência americana: "Em cada fase dessas opressões solicitamos reparação nos termos mais humildes; responderam a nossas petições apenas com repetido agravo". Observamos que as palavras do russo trazem o discurso da narrativa da guerra próximo ao contido no simbólico documento 
americano. Acrescentamos que o discurso ganha ainda mais relevância quando notamos ser feito nas palavras de um presidente russo, cujo país é historicamente inimigo dos Estados Unidos.

Há em nosso corpus um artigo do dia 06/08/2011 sob o título de "Syria Broadcasts Scenes of Destruction in Rebellious City". O que observamos é a destruição da cidade de Hamas de forma muito parecida com a descrita no documento americano "Saqueou os nossos mares, devastou as nossas costas, incendiou as nossas cidades e destruiu a vida do nosso povo", principalmente quando encontramos, na reportagem, o seguinte excerto, "showing burned buildings, makeshift barricades and deserted streets strewn with rubble". Semelhante à imagem descrita pelo documento americano, a reportagem descreve prédios queimados, barricadas improvisadas e ruas desertas, que podemos interpretar como a destruição da vida do povo.

Vejamos outras referências ao mesmo discurso no seguinte trecho, retirado de uma coluna de opinião e publicado em 29/03/2011:

6.6

Wednesday, President Assad is expected to announce that the country's almost 50year emergency law, used to stifle opposition to the regime, is going to be lifted.

Como mencionamos no capítulo 3, a Síria vivia em um estado de emergência que durou quase 50 anos, quando em 1963, o partido do Baath assumiu o poder por meio de um golpe militar. A lei dava autoridade ilimitada ao governo, restringia a liberdade e permitia que suspeitos que atentassem contra a segurança pública e nacional pudessem ser investigados e detidos, tal como mencionado no trecho "to strife opposition to the regime". Essa lei é constantemente citada em nosso corpus tal como a encontramos no excerto 6.6 e se alinha com o texto da declaração de independência americana nos termos da presença constante de tropas, da deturpação e da ausência da justiça.

Sem dúvida, encontramos em nossa análise muitos elementos que dialogam com o documento americano e que colocam o inimigo, a Síria, no mesmo imaginário da colonização inglesa nos Estados Unidos. Julgamos que, ao usar discursos emblemáticos do documento, a mídia busca ativar a memória discursiva, mesmo que o evento em si esteja, geográfica e culturalmente bem longe dos Estados Unidos. Ao 
trazer o fato à memória histórica americana, ele se fato torna familiar, posto que baseado em saberes arraigados na cultura americana, sendo, portanto, um fato inteligível.

\subsection{A construção discursiva da imagem: seu poder simbólico e cultural}

Além da inteligibilidade do conflito, a memória discursiva convoca valores da própria sociedade americana, fazendo com que o leitor tenha uma linha de pensamento linear, isto é, baseada em sua concepção de mundo e não no entendimento dos valores daquele que é diferente. Como já mencionamos, valores como liberdade são parte da cultura de um povo e, portanto, determinados por sua construção discursiva. Assim, não se procura entender a liberdade pelo ponto de vista do Outro, mas a partir de recursos da sociedade que são narrados. Todos esses saberes são o que Fairclough(1992) chama de "member resources", que permite um evento ser entendido de uma forma e não de outra.

Mesmo que grande parte desse processo aconteça de maneira inconsciente, ele se manifesta nas reportagens e nos artigos do jornal. Com isso, não estamos afirmando que jornalistas, escritores ou mesmo leitores utilizem, por exemplo, a declaração de independência americana, de forma racional e consciente, mas sim que de maneira constitutiva ela está presente na compreensão dos acontecimentos do País e de outras culturas, criando um quadro epistemológico de compreensão de si, do outro e da sociedade.

Hall (1992) afirma que as culturas nacionais são as principais fontes de identidade dos indivíduos em constante processo de formulação e de reformulação constituído pela representação. $O$ autor declara que as identidades são discursos que organizam nossas ações, nossa concepção de nós mesmos e do mundo. Todos esses sentidos são construídos nas estórias nacionais de ontem e de hoje, fazendo com que a identidade nacional se torne uma "comunidade imaginada" (ANDERSON, 1983 apud HALL, 1992).

Essas estórias são narrativas nacionais que remetem às origens, à história, às tradições e à noção de um povo original. Há conexões entre passado e futuro que formam a significação da cultura em uma série de discursos que buscam tanto a 
diferença quanto a unidade. Segundo Hall (1992), as identidades nacionais estão sempre subordinadas a jogos de poder, divisões e contradições internas, assim como os discursos.

Essa concepção de identidade nos leva a um questionamento aplicado ao nosso objetivo de pesquisa. Sabemos que muito da formação da nação americana se dá no período da colonização e da independência e constitui as bases discursivas que alicerçam muitos valores e crenças até a contemporaneidade, mas muito tem sido feito e escrito na nação que reforça, aprimora ou remodela esses conceitos. Examinamos um texto escrito em 1889 por Theodore Roosevelt sob o título de True Americanism.

Roosevelt torna-se presidente em 1901, acompanhado por uma série de novas dinâmicas internacionais. Segundo Junqueira (2001), Roosevelt fica famoso antes mesmo de se tornar presidente, na guerra hispano-americana, na qual desenvolve a imagem americana do cowboy, dos "homens impetuosos" que resgatam a mítica da fronteira. Segundo a autora, Roosevelt encarava a guerra como o momento no qual "as nações superiores demonstravam a sua superioridade, descartando assim as inferiores e melhorando a raça humana".

Como presidente, Roosevelt reforçou a Doutrina Monroe, afastando qualquer intenção europeia na América e causando muitos problemas de ordem diplomática. Para sua política na América Latina, segundo Junqueira (2001), Roosevelt desenvolve a política do Big Stick, que apoiado em valores extremamente preconceituosos, afirmava que os americanos deveriam, no trato com os latinos, "falar suavemente, mas com um big stick na mão". Grande parte dos americanos viam os latinos como preguiçosos e incapazes de instalar um governo. Dessa forma, as intervenções americanas na América Latina eram contínuas e, segundo Junqueira (2001), se davam de diversas maneiras, como ocupação, imposição de tratados econômicos, criação de bases militares, apoio a políticos favoráveis aos interesses americanos, dentre outras.

Em 1889, Roosevelt escreve "True Americanism", no qual ele define muitas características, idealizadas ou reais, do sentimento de ser americano, mesmo para aqueles que não haviam lá nascido, mas que optaram por lá viverem.

Uma das questões centrais de seu texto é a ideia de Patriotismo, que, segundo Roosevelt, pode ser expresso com a frase "O amor ao país é uma das 
virtudes elementares"14 (1889: p.31). E aquilo que ele define como Patriotismo é o mesmo que define Americanismo.

Roosevelt acreditava que a nação americana, dentre todas as outras, tinha nas mãos o destino dos anos a seguir e que essa excepcional vantagem americana levaria ou a um grande sucesso, ou a um grande fracasso. Roosevelt admitiu que, pessoalmente, ele acreditava no sucesso.

O presidente (1889) usa uma argumentação de quem conhece a importância da cultura na criação de uma identidade nacional. No trabalho, Roosevelt faz constante uso das instituições culturais e da literatura para se referir a uma maneira ampla de se pensar a América e definir patriotismo. Segundo ele (1889), "nosso patriotismo incluirá toda a raça humana e todo o mundo"15. (p.36)

Em boa parte do texto, Roosevelt ressalta a ideia de americanizar o imigrante que ali decidiu morar e construir sua vida. Essa americanização deve, entretanto, respeitar as crenças religiosas e os costumes de cada grupo, uma vez que não é necessário, para o autor (1889), que uma única crença seja estabelecida: a importância está no sentimento americano, e não na religião. Esse "espírito americano" está acima de qualquer outra ordem religiosa ou filosófica, e se define como um sentimento superior.

O texto de Roosevelt é um dos muitos outros que materializam a existência de um "espírito americano" construído discursivamente na nação que imprime forma a uma multiplicidade de outros pensamentos e crenças a ele atrelados.

Fazemos um paralelo entre esse americanismo e as verdades americanas mencionadas na introdução do capítulo. A guerra da Síria, mesmo não acontecendo em território americano nem sequer próximo dele ou de seus aliados, fere algumas dessas verdades que fazem parte do espírito americano e tornam-se um ataque a uma imagem simbolicamente construída do País. Ao ferir essa imagem, o direito de reconstrução é imediatamente despertado, fazendo com que a visão da mídia e a opinião pública trabalhem para sua reconstrução.

A mídia, tal como vista por Thompson (2009), é uma instituição cultural e, dessa forma, produtora de um poder simbólico. Assim, a atividade da mídia, ao narrar a guerra, pode representar e construir tanto o ataque à imagem quanto à defesa dela.

\footnotetext{
14 "love of the country is one of the elemental virtues" (1889, p.31). Nossa tradução.

15 "our patriotism will include the whole human race and all the world." (1889: p.36). Nossa tradução
} 
Procuramos observar de que forma as imagens de ataque ao "espírito americano" se processam na cobertura da guerra, e ainda como a mídia constrói a sua defesa.

Uma das construções mais recorrentes em nosso corpus é a narrativa da morte de rebeldes na Síria pelas forças do governo. Algumas imagens são bastante contundentes ao explorar a morte dos chamados inocentes, mais especificamente das mulheres e das crianças. O excerto abaixo, de uma reportagem de 19/03/2011, apresenta a seguinte descrição:

6.7

The funeral procession on Saturday became a protest in its own right, with marchers calling for more freedoms and an end to Syria's longstanding emergency law, witnesses said. They chanted, "The people want an end to corruption," and, "The blood of our martyrs won't be forgotten." They repeated the demands made in the march on Friday: that the mayor and a local security chief should be fired for their role in arresting of a group of children two weeks ago for writing protest graffiti.

O artigo descreve a imagem de um funeral. Trata-se de um funeral de rebeldes mortos em confronto com as forças do governo que acaba se tornando uma marcha de protesto com palavras de ordem sobre o fim da corrupção e a liberdade do País. O trecho também narra que os manifestantes querem a dispensa do chefe de segurança local e do prefeito, os quais prenderam um grupo de crianças por grafitarem protestos.

Citadas na reportagem, uma das frases de ordem proferidas pelos manifestantes que nos desperta a atenção é: "The blood of our martyrs won't be forgotten". Embora dita por manifestantes sírios, essa frase é bastante característica da cultura americana. A ideia de mártires que lutam por um futuro melhor, mesmo sacrificando a própria vida em benefício de seu povo, é muito recorrente na história e no imaginário americano.

Como estamos trabalhando com a questão da construção simbólica, da imagem discursiva, percebemos a recorrência de outras imagens, presentes no universo simbólico americano, seja por meio da literatura seja por meio da cultura popular. Foi, por exemplo, Abraham Lincoln que recebeu homenagem em forma de poema, de Walt Whitman, em Oh Captain, my Captain. Nesse poema, exalta-se 
aquele que lutou pela pátria para que o País se desenvolvesse, mas que no momento encontrava-se morto no deck do navio.

Outro exemplo é a canção "Do you hear the people sing", do musical "Les Miserable", que, apesar da origem francesa, torna-se quase que uma propriedade americana devido às infinitas produções da Broadway e de Hollywood e às características discursivas e ideológicas de seu conteúdo. Eis a canção:

\author{
Do you hear the people sing? \\ Singing a song of angry men? \\ It is the music of a people \\ Who will not be slaves again! \\ When the beating of your heart \\ Echoes the beating of the drums \\ There is a life about to start \\ When tomorrow comes! \\ (...) \\ Will you join in our crusade? \\ Who will be strong and stand with me? \\ Beyond the barricade \\ Is there a world you long to see? \\ Then join in the fight \\ That will give you the right to be free! \\ (...) \\ Will you give all you can give \\ So that our banner may advance \\ Some will fall and some will live \\ Will you stand up and take your chance? \\ The blood of the martyrs \\ Will water the meadows of France!
}

Voltando ao excerto 6.7, pode-se dizer que o artigo, ao faz referência à marcha do funeral, transforma-se em palavras de ordem de uma multidão raivosa, imagem que também pode ser vista na primeira estrofe da canção, precisamente nos versos "Do you hear the people sing? Singing a song of angry men? It is the music of a people Who will not be slaves again!" 
Já mencionado em nossa pesquisa, os rebeldes sírios são caracterizados como vítimas de um governo opressor, pois lutam por um país melhor, livre e justo. Assim também acontece nos versos da segunda estroge da canção:"Will you join in our crusade? (..) Beyond the barricade. Is there a world you long to see? Then join in the fight. That will give you the right to be free!". Tal como na canção, os sírios são "soldados" que partem para uma cruzada, atrás de uma barricada, para lutar pelo direito de ser livre.

Nos versos da última estrofe, há um chamamento para a luta que pode libertar e também matar, sendo que a morte dos mártires é o que banha as águas do país, que nunca se esquecerá deles. Importante observar que há no poema e na reportagem exatamente a mesma expressão "The blood of the martyrs," ambas alinhadas ao um mesmo discurso.

Esse tipo de luta, descrita tanto pela reportagem como pela canção, transforma homens comuns em heróis de um povo que luta por um ideal. Faz parte do imaginário ocidental essa representação da guerra, na qual os ideais valem mais do que a própria vida, pois garantem a permanência de valores que asseguram a liberdade de uma sociedade para futuras gerações.

Notamos que, ao construir a narrativa da guerra na reportagem, a mídia se utiliza de discursos que há tempos sustentam o pensamento e os ideais ocidentais e que são reproduzidos e fortalecidos em um movimento de constante retomada. Como afirmamos anteriormente, são as construções discursivas que orientam a percepção do outro e do mundo.

Com relação à imagem, importa que a guerra, mesmo representando a destruição e a morte, também representa a construção e a vida. Ao trazer a imagem de um povo em luta por um ideal, o discurso constrói a transformação, ou melhor, a evolução de um estágio inferior a um superior, a passagem da opressão à liberdade. Se pensarmos no "espírito americano", ele é o único que sobrevive e se fortalece, assim como acontece sempre que há uma tragédia no território americano. Muito se perde no 11 de setembro, mas o "espírito americano" sai fortalecido. Ideologicamente, a nação recobra seu patriotismo e se unifica na cruzada contra o terror: materialmente, outras torres de proporções ainda maiores são construídas. A imagem da destruição e da guerra, quando trabalhada por um discurso ideologicamente fundamentado e construído, pode ser um grande instrumento de poder simbólico. 
Já no discurso contra Bashar al-Assad está fortemente presente a sua vilanização. Essa imagem é construída, na maior parte das vezes, pela maneira como suas forças de segurança repreendem os protestos e promovem por todo o país. Em sua defesa, o presidente fala de uma conspiração cujo objetivo é destruir seu governo e o País. Um dos agentes dessa conspiração, segundo Bashar, é os Estados Unidos. No excerto seguinte, o presidente expressa essa opinião, razão porque analisamos como ela foi tratada na reportagem. Escolhemos alguns excertos de um artigo de 30/03/2011 que tem como título "Syrian Leader Blames "Conspiracy" for Turmoil".

6.8

CAIRO - The much-anticipated speech by the Syrian president, Bashar al-Assad, on Wednesday was a well-choreographed effort to showcase his firm grip on power, as he refused to offer concessions and labeled pro-democracy demonstrators as either "duped" or as conspirators in a plot to destroy the nation.

6.9

Instead, the speech was a throwback to a vanishing era of leader worship, with audience members bounding from their seats to praise the president and crowds waving his picture.

6.10

Mr. Assad fell back on the strongman's standard justification for holding on to power: "The first priority," he said, "was the stability of Syria."

6.11

He acknowledged that Syrians' demands had not been met, but said that the grievances were "used as a cover to dupe the people to go to the streets." He added that the state would not put any changes into effect under pressure. "We are not in favor of chaos and destruction."

6.12

As for the recent unrest, he said it was both misguided and manufactured by saboteurs who want "to fragment Syria, to bring down Syria as a nation, to enforce an Israeli agenda." Within hours of Mr. Assad's speech, residents in the restive northern city of Latakia took to the streets in protest, and armed forces once again opened fire 
O artigo descreve e comenta o pronunciamento feito pelo presidente à nação depois do início dos conflitos. Já no primeiro excerto (6.8), são colocadas em questão a sinceridade e a espontaneidade do pronunciamento: a expressão "wellchoreographed effort' já descredibiliza qualquer intenção verdadeira e dá o tom à reportagem, sugerindo que todas as falas do presidente foram coreografadas no esforço de representar algo que não é real. Esse esforço de Bashar intenciona justificar suas atitudes de não abrir concessões nem atribuir aos movimentos pródemocracia um caráter falso e em consonância com um enredo cujo objetivo é destruir a nação. Os argumentos de Bashar não ganham veracidade após toda a cena ter sido adjetivada como um esforço bem coreografado.

O excerto 6.9 intensifica a farsa, ao afirmar que ela está em consonância com uma era sob desaparecimento. Observamos que o texto coloca em cheque a atualidade da imagem no cenário de um país em guerra civil ao descrever não só os membros do partido levantando-se de seus assentos para ovacionar o presidente como também o povo carregando fotos de seu governante.

Adiante, nos excertos 6.10 e 6.11, Bashar oferece as justificativas para se manter no poder e não promover as mudanças exigidas pelos manifestantes, porém, mais uma vez, tais justificativas são qualificadas negativamente. A frase "the strongman's standard justification for holding on to power" está ligada discursivamente ao mesmo universo da farsa descrita anteriormente por "well-choreographed". Em meio a todo o discurso construído, qualquer tentativa de dar credibilidade à fala de Bashar é frustrada. A afirmação do presidente de que as manifestações são fabricadas por sabotadores que querem acabar com o poder da Síria para alinhar-se com os interesses de Israel perde qualquer força argumentativa no discurso construído, tornando-a mais uma farsa do governo. Ressalta-se que logo após a citação do presidente, onda de protestos continua e é recebida a tiros pelas forças armadas.

A palavra de Bashar, farsa ou não, assim como a sua imagem e a imagem de que há uma conspiração, é totalmente desconstruída pela linha discursiva do texto. Se a imagem do presidente, bem como a de seus apoiadores, oferecia qualquer forma de ameaça à imagem americana no que diz respeito a uma conspiração ou a um apoio a Israel, a ameaça desfeita no discurso ao atribuir ao governante a imagem de farsante. 
Colocamos em paralelo os dois lados do conflito representados pela mídia, usando um texto de 02/04/2011 sob o título de Thousands Protest in Syrian Cities, Facing Attacks, Residents and Rights Groups Say no qual encontramos uma série de descrições sobre o governo e sobre os manifestantes:

O texto em questão faz basicamente um levantamento dos protestos em todo o país, fornecendo informações sobre quem luta contra quem e por que. O texto caracteriza os dois grupos envolvidos: manifestantes e forças de segurança do governo. Apontamos, no quadro abaixo, a seleção de expressões utilizadas para qualificar e descrever os dois grupos, bem como para referir-se a eles.

6.13

\begin{tabular}{|ll|}
\hline \multicolumn{2}{|c|}{ MANIFESTANTES } \\
\hline Assad & Unsatisfied with yet more vague promises of reform from Presitent Bashar al- \\
\hline & Marched ... only to be met with gunfire \\
\hline & Residente of Douma ... speaking anonymously \\
\hline Were trying to march when the attacks scattered them \\
\hline "Freedom, not citzenship" \\
\hline Syrian Human Rights - 73 people have been killed \\
\hline
\end{tabular}

6.14

\begin{tabular}{|l|}
\hline GOVERNO \\
\hline Beating them with sticks or shocking them with cattle prods \\
twarting the conspiracy. \\
\hline Balling for "national unity and preserving the security and stability in Syria and \\
\hline Grand conspiracy to destabilize Syria \\
\hline Failed to deliver on promised reform \\
\hline Act violently \\
\hline Crushed a nascent democracy \\
\hline Mr assad has talked about reform often but carried out very little \\
\hline He hates being pushed around \\
\hline The government deploy forces across the country \\
\hline Never seen as many security forces in Syria \\
\hline They raided apartments of suspected protesters \\
\hline
\end{tabular}

Nesse texto, as expressões destacadas revelam uma mesma voz para qualificar os dois grupos. O enunciador assume uma posição contra o governo Bashar 
e outra a favor dos manifestantes. Essa mesma voz, evidentemente da mídia jornalística americana, demonstra ser humanitária e democrática, fruto de um "espírito americano" que forma a base do sujeito enunciador e de sua percepção de mundo.

$\mathrm{Na}$ caracterização dos manifestantes e na narrativa, pode-se perceber que a posição humanitária apresenta-se de maneira indireta nas expressões "only to be met with gunfire" e "attacks scattered them, 72 people have been killed e speaking anonymously", que retratam a opressão das forças do governo.

Já a posição democrática aparece nas expressões: "freedom", "unsatisfied with yet more vague promises of reform". Essa mesma posição surge de forma mais evidente quando analisamos as referências ao governo: "Beating them with sticks or shocking them with cattle prods", "barred most foreign jounalists to enter the country", "Failed to deliver on promised reform", "Act violently" e "Crushed a nascent democracy."

Todas essas expressões denotam um sentido violento e totalitário que se contrapõe à posição democrática e humanista do enunciador. Não notamos a presença de uma voz oposta, que valorizasse as ações dos agentes de segurança do governo, ou que tomasse a posição dos manifestantes como ilegítima. Essa imagem do enunciador democrático e humanitário tanto ao se referir aos rebeldes, como ao governo sírio legitima as ações dos manifestantes e os coloca na mesma posição ideológica do enunciador, fazendo com que surjam princípios e ideais que, discursivamente, estão acima da nacionalidade e da cultura do próprio enunciador. Valores, como já afirmamos, não existem no vácuo; eles estão interligados a discursos e projetos nacionais.

Visto nessa perspectiva, a imagem que a mídia cria da guerra ao descrever os dois lados do confronto, pode ser interpretada de maneira simbólica, pois não corresponde a valores, ideologias e crenças da cultura local. A imagem existe apenas no plano ideal, simbólico, contribuindo para a construção do poder simbólico do local de onde a mídia fala.

Em um texto datado de 19/09/2011, já explorado nessa pesquisa, sob o título de "US Is Quietly Getting Ready for Syria Without Assad", a jornalista Helene Cooper traça um panorama de ação americana numa síria sem o Presidente Bashar al-Assad, ou seja, em que se prevê o destino do País após a saída do governante e o papel americano no País e suas alianças. 
Notamos que há uma grande força na voz da liderança americana, representada pelo presidente Obama e por outros membros de seu governo. Encontramos também, uma fraca, mas presente, voz independente, que aponta traços discursivos opostos. Para auxiliar a análise, dividimos nos quadros abaixo excertos que representam essas duas posições:

\subsection{5}

VOZES DE UMA LIDERANÇA INSTITUCIONALIZADA

\begin{tabular}{|c|}
\hline $\begin{array}{l}\text { Obama administration officials say they are leaving in place the } \\
\text { American ambassador (...) so that he can maintain contact with opposition } \\
\text { leaders. }\end{array}$ \\
\hline $\begin{array}{l}\text { Officials at the State Departament have also been pressing Syria`s } \\
\text { opposition leaders to unite as they work to bring down the Assad government } \\
\text { and to build a new government. }\end{array}$ \\
\hline $\begin{array}{l}\text { The Obama administration is determined to avoid a repeat of the } \\
\text { aftermath of the American invasion of Iraq. }\end{array}$ \\
\hline $\begin{array}{l}\text { Another Obama administration official said that with } 90 \text { percent of } \\
\text { Syria's oil exports going to Europe, shutting the European market to Damascus } \\
\text { could have a crippling effect on the Syrian economy and could put additional } \\
\text { pressure on Mr. Assad's government. }\end{array}$ \\
\hline
\end{tabular}

6.16

\section{OUTRAS POSIÇÕES}

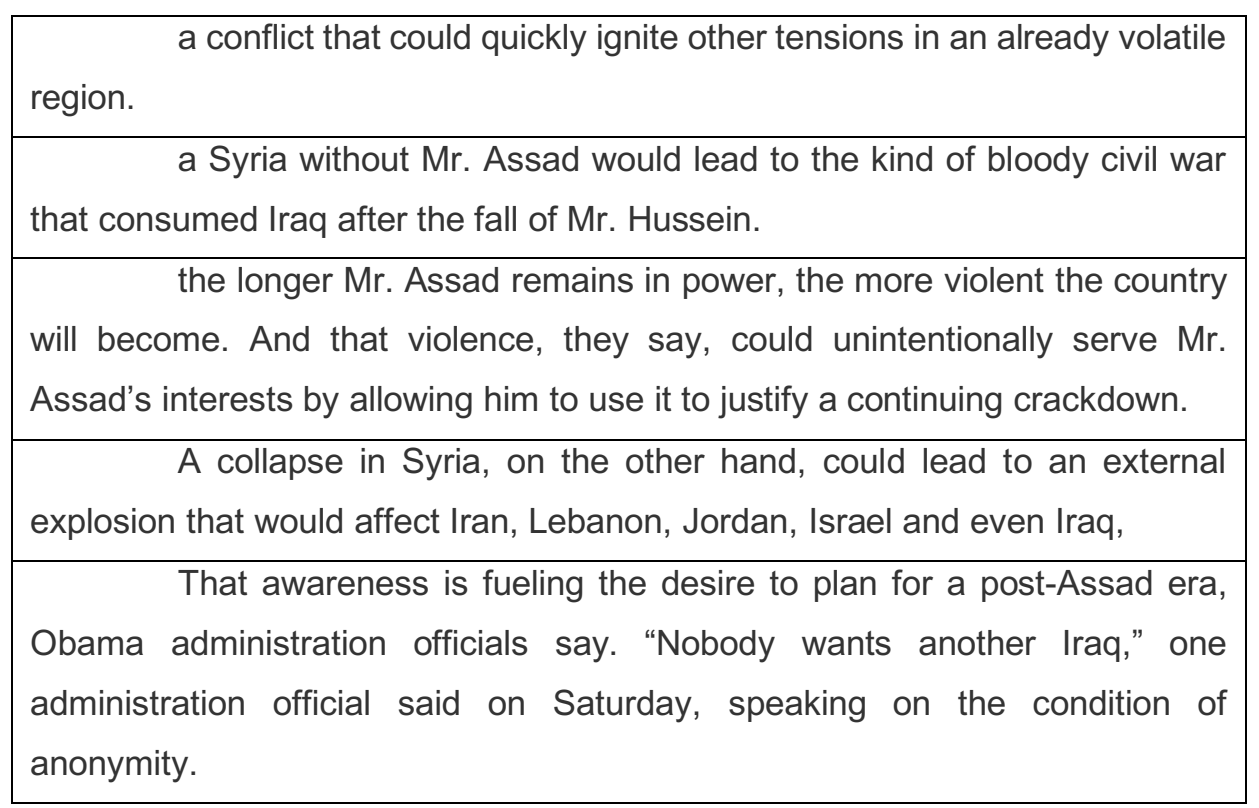


Os excertos do primeiro quadro apontam para uma voz institucional que busca a negociação, a diplomacia, as alianças e as estratégias. Notamos a construção da imagem de uma liderança americana que adota um papel estrategista, prevendo, planejando e analisando fatos e consequências como num jogo previsível. Claramente são falas do governo Obama, devidamente citadas pela jornalista, nas quais o governo se apresenta como o negociador, o estrategista, aquele que busca a melhor solução de forma racional e cautelosa.

No segundo quadro, a posição muda, passando da racionalidade à incerteza, ao desenhar um destino não previsível que, eventualmente, pode despontar no horizonte do conflito. Percebemos uma voz que não está certa do destino do País sem Assad. Essa posição vê muitas variáveis e indica o receio do terror se espalhar ainda mais, tornando-se, assim, uma situação não tão previsível como a imagem anterior queria demonstrar.

As duas posições são antagônicas, mas complementares. A primeira se ligaria à preservação de uma face positiva do governo americano, uma imagem construída para fora: já a segunda representaria a face negativa do governo, uma imagem interna, que responde às pressões e às vozes internas da própria liderança. Mas ambas as posições emergem de um mesmo local enunciativo. No geral, compreendemos que não há construídas no jogo discursivo duas imagens, mas uma única imagem que está ligada ao mesmo "espírito americano" que, como afirmou Roosevelt, por assumir a posição de mediador de conflitos, os Estados Unidos estão em uma posição de "excepcional vantagem americana que levaria a um grande sucesso ou a um grande fracasso". Em nenhum momento a contradição fere a imagem americana, apenas apresenta faces diferentes da mesma construção.

Se avançamos um pouco no desenvolvimento da narrativa sobre a guerra, num momento em que se discute uma possível intervenção militar na Síria, encontramos o texto intitulado "Obama and Cameron News Conference", originalmente publicado, em 14/03/2012, num blog do jornal que comenta minuto-aminuto a conferência de imprensa na Casa Branca, com a presença dos dois líderes. Dividimos as falas em dois grupos: o primeiro relacionado ao dever de intervir na Síria, e o segundo, à busca por soluções não militares. 
6.17

\begin{tabular}{|l|}
\hline INTERVIR MILITARMENTE \\
\hline our natural instinct is to act" \\
the only thing to do is to ratchet up the pressure on the "bloody, \\
broken, brutal regime" \\
The vast majority of the American people and British people \\
understand" why the wars are being fought \\
Both leaders say they need to end the Assad regime, stop the killing \\
quickly and step up humanitarian aide in Syria.
\end{tabular}

6.18

\begin{tabular}{|l|}
\hline AGIR NÃO MILITARMENTE \\
\hline $\begin{array}{l}\text { His goal is a "soft landing" for the Syrian people as opposed to a } \\
\text { "hard landing" that could end up in a civil war even worse than what's going on }\end{array}$ \\
the best thing to do is seek international unanimity that Syria's \\
behavior is "contrary to every international norm." \\
"Anybody who answers a poll question about war saying \\
enthusiastically, 'We want war,' probably has not been involved in war," he \\
says.
\end{tabular}

O primeiro quadro nos mostra uma reposta àqueles que querem a intervenção militar na Síria a favor de valores humanitários e democráticos. O enunciador responde a uma demanda de ação, afirmando não desconhecer ou desconsiderar a necessidade. No segundo quadro, a necessidade é transformada em responsabilidade global: não cabe apenas a um ou dois países decidirem a intervenção; há a necessidade de um consenso, de dividir as responsabilidades em uma decisão internacional.

O texto coloca principalmente o presidente Obama em duas posições diferentes; uma humanitária, que "instintivamente" quer agir, e outra, de respeito à demanda nacional e internacional de um pacto diplomático. Uma imagem americana consciente se desponta a partir das falas do quadro 6.17 , que se coloca em posição humanitária e afirma não ignorar a importância de uma ação mais concreta.

Em seguida, no quadro 6.18, o texto constrói uma imagem de precaução, isto é, de quem parece não querer assumir sozinho a responsabilidade, não se responsabilizar isoladamente pelas consequências de uma intervenção militar. Esses dois momentos podem ser interpretados a partir de um mesmo desenvolvimento 
discursivo: é apresentada uma imagem solidária em que se mostra não estar cego ao desenvolvimento da guerra na Síria, pois mostrar-se cego seria prejuízo à imagem de um país que luta por valores democráticos e defende a liberdade, não somente em seu território, mas em todo o mundo. É também nesse sentido que tomamos as palavras de Roosevelt: "nosso patriotismo incluirá toda a raça humana e todo o mundo". 16

Por outro lado, encarar sozinho a responsabilidade da intervenção militar na Síria também poderia ferir a imagem americana, colocando-a em um padrão imperialista e de certa forma autoritário. Construindo a contradição, o texto modaliza as duas posições sem ferir a imagem e o "espírito americano".

Tanto os Estados Unidos quanto o Reino Unido, apesar de favoráveis, procuraram evitar, no início, a intervenção, temendo uma reação contrária da opinião pública que, entre outras coisas, receava a reprodução do conflito vivido no Iraque, e a ameaça de que as armas pudessem cair em mãos islâmicas, principalmente a AlQaeda. Isso provocaria, além de uma negativa na opinião pública, uma ameaça aos países.

Sabemos que, como muitas outras guerras no mundo árabe, a guerra na Síria se torna, em momento posterior, uma guerra contra o terror. Depois de construída a imagem do vilão e associá-la ao terror, nos moldes apresentados por Chomsky sobre os Rogue States, a mídia começa a representar a guerra da Síria não mais como fato local, mas como uma potencial ameaça aos Estados Unidos, quer nas concretas ações terroristas quer no plano ideológico. Além de tornar a guerra inteligível para todos, pois há muito conhecemos a guerra contra o terror, o discurso da mídia torna a guerra na Síria maior, criando uma imagem que ultrapassa as fronteiras do próprio País.

Para analisar esse momento, escolhemos uma reportagem de 21/10/2013 sob o título de "Quaeda-Linked Group Is Seen Complicating the Drive for Peace". Como afirmado, nesse artigo, assim como em muitos outros, a guerra na Síria começa a se transformar em uma guerra contra o terror, o que a aproxima da guerra no Afeganistão e da guerra no Iraque. Muitos artigos começam a ligar facções terroristas aos confrontos na Síria, fazendo com que a guerra na Síria deixe de ser uma guerra local e transforme-se na guerra mundial contra o terror. Dividimos o texto em duas posições

\footnotetext{
${ }^{16}$ ROOSEVELT, T. (1889) True Americanism. p. 36
} 
distintas, uma que claramente constrói a chamada guerra contra o terror e outra de caráter mais moderado.

6.19

\begin{tabular}{|l|}
\hline GUERRA CONTRA O TERROR \\
\hline Al Qaeda has undermined the chances of negotiating an end to the \\
conflict, a senior State Department official said on Monday. \\
\hline And by presenting an extremist face to the world, the official said, the \\
group is aiding Mr. Assad's efforts to portray the conflict in Syria as a tug of war \\
between the government and jihadists. \\
\hline it will make the task of extracting concessions from the regime at the \\
negotiating table more difficult \\
\hline It has been very disruptive to our cross-border efforts - very \\
disruptive," the official said. \\
\hline Even as the Obama administration has pointed to the growing role of \\
extremists in Syria, its policy has continued to be a target for critics, who \\
complain that the United States has offered the moderate Syrian opposition too \\
little, too late.
\end{tabular}

6.20

\begin{tabular}{|c|}
\hline MODERADA \\
\hline A principal goal of the peace conference, which is expected to be held \\
next month in Geneva, although no date has been set, is the establishment of \\
a transitional government "by mutual consent" of Syrians that would not include \\
Mr. Assad. \\
\hline But Mr. Kerry insisted that the Syrian government's military gains had \\
not weakened the Obama administration's diplomatic strategy to establish a \\
transitional government in Syria that would not include Mr. Assad. \\
\hline The United States and five other world powers have been in talks with \\
Iran on how to limit its nuclear program.
\end{tabular}

Podemos notar uma mudança no discurso da mídia. Em todo o período em questão, assim como nos excertos do primeiro bloco, observamos uma mudança na construção discursiva. A atitude moderada e diplomática começa a dar lugar a uma guerra antiga, a guerra contra o terror. A ameaça de que o Al-Qaeda possa, na ausência do governo de Assad, tomar a posição de poder no País, começa a ficar bem mais visível. Essa possibilidade afasta as negociações diplomáticas e coloca a 
Síria no mesmo bloco de Iraque e Afeganistão. Uma intervenção passaria a ser vista como uma investida contra o terror, e não como uma nova guerra em um novo local.

Quando falamos em construção de um poder simbólico, aludimos ao papel fundamental que a mídia exerce. No âmbito da política externa, a mídia possui papel essencial nessa mudança de dinâmicas, pois ela faz a principal ligação entre lideranças e público, tornando-se central na construção e na manutenção dos discursos. Além disso, ela, por um lado, funciona como mediadora do fluxo de informações que atende os fornecedores de informações, ou seja, as lideranças políticas organizadoras do que deve ser veiculado, e, por outro lado, ela também está atenta às demandas do público, seus reais consumidores em caráter não somente econômico, mas também ideológico.

Para finalizar a discussão desse capítulo, gostaríamos de levantar a questão sobre em que a representação de uma guerra em terra distante e culturalmente tão diferente dos Estados Unidos pode contribuir para a construção de um poder simbólico, já que, a princípio, a guerra não representa nenhuma ameaça concreta à Nação.

Hall (1998) examina a questão da representação do diferente, ou do Outro, a partir de quatro disciplinas: a Linguística, a Antropologia, a Filosofia e as recentes teorias da linguagem. A linguística vê o "diferente" como essencial para o estabelecimento do sentido, uma vez que sem o "diferente" não existe o sentido. $O$ preto adquire sentido em oposição ao branco, o mau em oposição ao bem. São os binômios, ou os pares opostos, que marcam as diferenças de sentido. A visão antropológica estabelece o sentido às coisas a partir de diferentes posições num sistema de classificação. Nessa perspectiva, são as diferenças que marcam a base da cultura. Já para as recentes teorias da linguagem, mais especificamente as de Bakhtin (1929), acredita-se que é no diálogo com o Outro que o sentido é construído. O conceito de dialogismo pressupõe o diálogo entre interlocutores e o diálogo entre discursos. Para Bakhtin não é possível pensar o homem sem as ligações com o Outro. É somente na sua relação com o Outro e com outros discursos que homem se constitui.

Hall complementa que esse debate sobre a diferença e o Outro tem por objetivo não comparar ou julgar teorias, mas sim mostrar que, em diferentes áreas do conhecimento, excludentes ou não, o papel do Outro e o da diferença são 
fundamentais e de grande importância. Percebemos, porém, que o conceito de diferença é "ambivalente", como diz Hall:

"... difference is ambivalent. It can be both positive and negative. It is both necessary for the formation of language and culture, for social identities and a subjective sense of the self as a sexed subject - and at the same time, it is a threatening, a site of danger and negative feelings, of splitting, hostility and aggression towards the Other." (HALL, 1998: 238)

Observamos que, em todas as teorias, a questão do outro pode ter diferentes perspectivas. O Outro é necessário para a produção do sentido, da cultura, da subjetividade e da linguagem, ou seja, sem ele nada existiria nem sequer haveria sentido. Apesar disso, e ao mesmo tempo, o Outro pode, na Linguística por exemplo, provocar oposições binárias reducionistas e excluir uma gama de sentidos existentes entre os opostos. $\mathrm{Na}$ antropologia, podemos fazer classificações a partir de lugares errados, ou então não conseguirmos enquadrar apropriadamente um elemento em alguma categoria. Na psicanálise, o problema é visto da seguinte forma: se o indivíduo é formado a partir da existência do Outro e, por isso mesmo, nunca está completo, algo sempre falta, gerando, assim, um sentimento de incompletude.

De acordo com Hall (1998), a representação classifica simbolicamente nossas relações com o mundo, gerando sentidos por meio da linguagem. A identidade nada mais é do que uma representação criada para nos classificar dentro deste sistema simbólico. E assim como a própria representação, a existência da identidade necessita de algo que está fora dela, ou seja, outra identidade. Por isso podemos dizer que a identidade também nasce a partir da diferença, do contato com o Outro. É por meio dos sentidos produzidos pela representação que damos sentido àquilo que somos, por isso mesmo a representação constrói lugares a partir dos quais podemos falar e agir.

Por tratar-se de um fenômeno social, a identidade está diretamente engendrada com posições ideológicas e com relações de poder. Ela sucumbe a ideologias, economias e culturas dominantes. O imperialismo, entendido de acordo com Said (1993, p. 40) como "a prática, a teoria e as atitudes de um centro metropolitano governando um território distante", também pode ter grande participação e influência no jogo de formação e transformação de identidades.

A guerra em uma terra distante e em uma cultura totalmente distinta tem, em nossa visão, a função de construir um poder simbólico que valoriza o discurso de 
formação da identidade nacional, no nosso caso, chamado de "espírito americano". Ao valorizar o discurso, contrapondo-o a outras culturas, o projeto Imperial americano se concretiza não somente no âmbito nacional, mas também internacionalmente.

Com isso, primeiramente buscamos compreender a questão do valor, defendida na introdução do capítulo, a fim de percebemos que a narrativa da mídia encaixa a guerra na Síria em um quadro conceptual ideológico americano, fazendo com que a guerra em um lugar distante e culturalmente diferente se torne inteligível ao mundo ocidental. Em seguida, sendo a mídia uma instituição que constrói um capital simbólico, analisamos a questão da construção de imagens discursivas que visam preservar as tradições de um "espírito americano" e, ao mesmo tempo, criar mecanismos de reorganização quando a imagem americana é atacada de alguma forma. Por último, discorremos sobre a importância da representação do Outro como um instrumento de definição do Eu. Ao narrar a guerra na Síria, a mídia define, valoriza e expande os valores nacionais do local onde se encontra.

O retrato da guerra feito pelo jornal The New York Times encontra-se orientado por uma visão americana que constitui a produção jornalística, ao mesmo tempo em que solidifica e expande essa mesma ideologia. Acreditamos que por tratarse de uma referência jornalística no mundo, o jornal exerce o papel de um veículo Imperial, disseminando internacionalmente os valores nacionais americanos, e fazendo com que a guerra na Síria tenha uma única forma de inteligibilidade. 


\title{
Conclusão
}

\begin{abstract}
O poder disciplinar é com efeito um poder que, em vez de se apropriar e de retirar, tem como função "adestrar"; ou sem dúvida adestrar para retirar e se apropriar ainda mais e melhor. (FOUCAULT, 1975, p.143)
\end{abstract}

No início da pesquisa, afirmamos que nossa percepção da realidade e da própria realidade do outro é construída com base em discursos que se estabelecem dentro da nossa cultura, além do que, compreende aquilo que é estranho ao nosso local, que pertence a uma outra cultura, só é possível se pudermos fazer um esforço crítico que nos tire das categorias que nos constituem. Fazer esse esforço é colocarmo-nos em estado de reflexão com relação aos discursos que nos cercam, compreendendo que as verdades estão associadas a mecanismos de manutenção, construção e expansão de poder.

Dessa maneira, ao retratar a guerra que acontece em outra cultura, distinta da nossa, a narrativa pode tornar-se uma projeção do desejo do narrador e não uma compreensão mais ampla do universo do narrado. Por isso, defendemos, nessa pesquisa, a tese de que, ao retratar a guerra na Síria, o jornal The New York Times reflete um projeto de soberania mundial americano que tem como objetivo sua própria expansão.

A história americana é repleta de momentos de expansionismo, seja em âmbito interno ou externo. O país é fundado com base, entre outras ideias, no mito da fronteira, que se caracteriza como um espaço aberto de possibilidades infinitas. No momento da colonização, ainda havia em território americano, muita terra para ser conquistada, um grande continente à disposição de seu colonizador. Com a ocupação de toda a área do País, desenvolve-se a necessidade de expansão para outros territórios, quer na América quer em outras partes do mundo. A expansão americana é ao mesmo tempo, territorial, econômica e ideológica. Como vimos nesta pesquisa, é parte integrante da identidade do País ser o modelo de construção social, política e econômica exportado para o mundo.

Seguindo esse percurso, este trabalho observou de que maneira a mídia americana, especificamente o jornal The New York Times, constrói a guerra e aqueles que nela participam. Vimos que esse projeto expansionista americano pode, 
ideologicamente, ser notado em instituições de caráter internacional, como as Nações Unidas, e que a mídia americana constrói a guerra e a cultura do diferente de acordo com seus próprios valores culturais, atribuindo, assim, características ao outro e ao mundo que são projeções de seus desejos e de sua ideologia.

Para a elaboração da pesquisa propusemos um caminho teórico, que compreendesse a articulação do discurso em sua relação com a história, com o social e com o meio no qual ele se materializa.

No capítulo 1, observamos o funcionamento e a estrutura do discurso, segundo a concepção foucaultiana (1971); para isso, nos apoiamos em sua ideia de que existem nas sociedades certos discursos ritualizados que se contam e recontam nas narrativas nacionais. São ritualizações que dão origem a novos discursos e que sempre que invocados fazem reaparecer os pressupostos do discurso primeiro. Ao perceber em nossa análise que o jornal The New York Times traz do passado histórico americano muitos valores ideológicos em sua narrativa sobre a guerra na Síria, entendemos como esses discursos constroem a imagem da guerra como uma série regular de acontecimentos conforme a concepção foucaultiana de discurso. Também notamos que a guerra se constitui nos enunciados que são anteriores ao próprio objeto.

Ainda no primeiro capítulo, tomamos novamente as ideias de Michel Foucault, tais como explicitadas por Dreyfus e Rabinow (1995), para definir nossa concepção de episteme, vista como um conjunto de relações discursivas que delimitam e definem os saberes e as verdades. A seguir, buscamos uma aproximação com a constitução do discurso político, visto na perspectiva de Charaudeau (2005) e Courtine (2006). Aqui encontramos o princípio de legitimidade e soberania, segundo o qual a instância política busca na instância cidadã a legitimidade para que a ação política se desenvolva. O comportamento dos cidadãos está fortemente arraigado no discurso nacional, em uma série de crenças e valores que quando materializados no plano discursivo constroem um ideal social, base de toda a ação política.

No capítulo 2, desenvolvemos um estudo sobre a mídia afim de compreender a estrutura jornalística em diferentes perspectivas. No início, investigamos o que transforma um fato em notícia e o que faz com que alguns acontecimentos tenham relevância e outros não. Concluímos que há todo um universo cultural e ideológico para a seleção do que pode se transformar em notícia, universo que se utiliza de critérios socialmente constituídos. Segundo Hall (2009), esse processo de seleção é 
exterior ao fato, pois a mídia se utiliza de fontes externas ideologicamente construídas. Lembramos que para Charaudeau (2005), a instância política é a grande fonte de informações da mídia. Dessa maneira, a mídia transforma-se em uma grande arena de luta, fazendo com que, como afirmam Baum e Potter (2008), ela se torne uma commodity de mercado por meio da qual a instância política tenta obter o controle.

No terceiro capítulo, construímos um panorama histórico e crítico sobre o tema de nosso estudo. Delimitamos como corpus deste trabalho a guerra na Síria, mais especificamente os momentos iniciais da guerra durante os anos de 2011 a 2013. Como apontamos no capítulo, a guerra na Síria faz parte de um movimento que acabou sendo chamado de Primavera Árabe numa alusão à Primavera de Praga na qual houve uma tentativa de reformas políticas que buscavam a democratização na República Tcheca, durante a dominação soviética, logo após a Segunda Guerra Mundial.

Por termos como objeto de estudo um jornal estadunidense, julgamos necessário iniciar o capítulo com uma série de estudos críticos sobre as relações dos Estados Unidos com o mundo árabe. Buscamos apoio nas teorias de Said (1993, 1999 e 1997) e no trabalho de Michael Hardt e Antonio Negri sobre Império (2001). Por meio dos autores, pudemos compreender a noção de Império, que extrapola os limites de fronteiras e se define como um aparelho de descentralização e desterritorializacão que, em última análise, busca incorporar o mundo inteiro em suas fronteiras ideológicas. Contamos também com a interpretação de Chomsky (1999) sobre aquilo que ele chama de "Rogue States" e de vilanização do Oriente, os quais constituem um discurso sobre o "diferente" colocado em situação de inferioridade em relação ao Ocidente. A partir do trabalho de Chomsky (2005), pudemos entender como a mídia americana fabrica um consenso sobre o Oriente, fazendo com que qualquer conflito na região seja visto ou como uma ameaça ou como fato impossível de ser tolerado, o que pode legitimar a ação de uma elite política.

Os capítulos seguintes $(4,5$ e 6$)$ foram destinados à análise de nosso corpus. A divisão se estabeleceu de acordo com a articulação entre o tema proposto e nossa pesquisa teórica: o capítulo 4 investigou analiticamente as estruturas do discurso, teoricamente estudadas no capítulo 1; o capítulo 5 analisou os efeitos dos estudos históricos e das críticas na relação dos Estados Unidos com o Oriente; e, por último, o capítulo 6 discutiu as questões específicas da mídia. 
O caminho analítico proposto no capítulo 4, entendeu os discursos de conformidade com sua constituição ideológica. O sujeito enunciador, nesse caso a instituição jornalística, é constituído a partir de discursos presentes na sociedade americana desde sua formação, como os princípios de democracia, liberdade e justiça. O discurso da mídia não diverge do discurso dos atores políticos, pois os valores que os constituem são histórica e culturalmente localizados e fazem parte de um projeto nacional. Os discursos antagônicos e contraditórios aparecem como exteriores à formação discursiva do enunciador e são assimilados como resultados de forças que podem ameaçar um projeto de expansão nacional.

Quanto aos objetos, a guerra e o inimigo são construídos a partir da posição ideológica e da formação discursiva daquele que tem o direito à fala. Tanto a guerra como a figura delineada do inimigo obedecem às categorias que estão presentes em um saber construído pelo discurso americano. A mídia se legitima ao invocar uma construção ideológica nacional que antecede qualquer discurso sobre a guerra e sobre o inimigo. Esse modelo americano tem origens lluministas e, como vimos, se baseia em uma abstração genérica das ideias do direito à vida, à liberdade e à busca pela felicidade. Todos esses direitos são culturalmente construídos, portanto sua compreensão e interpretação mudam em diferentes culturas. Entretanto, observamos que há nesse projeto americano e ocidental uma estratégia para transformar um projeto local em um projeto global, desterritorializando o que é local e expandindo assim os domínios do Império.

No capítulo 5, delineamos os domínios desse Império, conforme proposto por Hardt e Negri (2001). Para desenvolver nossa análise, iniciamos o capítulo observando o discurso contido na Declaração dos Direitos Humanos e na forma como ele constitui o discurso da guerra na Síria. Consideramos que essa Declaração é construída a partir por valores de um projeto ideológico americano que se alarga em âmbito internacional e que, por meio de mecanismos de controle da paz e da ordem mundial, visa expandir a noção de soberania. A mídia constrói, pela narrativa do debate sobre a guerra na Organização das Nações Unidas, um caminho de consensos que posiciona a instituição numa posição de soberania mundial, garantindo uma aparente neutralidade na resolução de conflitos. A Declaração dos Direitos Humanos torna-se, dessa forma, um documento inquestionável, que atribui a seu discurso que um caráter soberano. 
Em seguida, desenvolvemos, com base na narrativa da guerra na Síria, a noção de expansão da soberania americana. O modelo americano é fundado na noção de que o poder vem de um corpo social e tem nele o seu único objetivo. Sendo o povo soberano, é seu direito derrubar governos quando esses direitos não são garantidos. Uma contradição se estabelece no caso da guerra na Síria pois, ao julgar que as liberdades estão sendo violadas no país, o discurso americano viola o princípio de soberania do povo sírio. Dessa forma, o discurso deve se reinventar para que o conflito que emana do próprio princípio norteador do discurso possa ser englobado. $\mathrm{O}$ caráter expansionista do discurso americano é inclusivo; ele não busca destruir o outro, mas regular as contradições internas para que a ideologia que o constitui possa ser fortalecida e constantemente expandida.

Quando o discurso estabelece verdades e valores, ele passa a constituir um saber que faz parte do corpo social, e esse passa a exigir que seus direitos, valores e verdades sejam garantidos, transformando tanto o discurso quanto as contradições inerentes. Dessa maneira, toda a formação ideológica que encampa esse projeto é fortalecida e expandida, assim como a ideologia americana.

Por fim, no capítulo 6, dedicamos as análises ao estudo do papel da mídia como produtora de material simbólico que está em consonância com um "espírito americano", dando inteligibilidade à guerra e construindo imagens que garantem o fortalecimento de valores culturais americanos. Iniciamos investigando como os textos produzidos pela mídia se conectam a outros materiais simbólicos da cultura americana em uma tentativa de fazer com que a guerra, em um lugar distante e diferente, possa ser compreendida pelo seu público leitor. Ao vincular os discursos, os textos da mídia passam a construir uma guerra que é familiar ao leitor, repleta de significações que fazem parte de um universo discursivo americano, mas distante de um universo sírio.

Por se tratar de dois universos culturais diferentes, notamos a existência de um conflito entre o eu e o outro. Nessa relação, o outro passa a ser uma ameaça à imagem construída do sujeito, fazendo com que aconteça no plano da mídia uma reformulação da imagem que preserve as características de um "espírito americano". Ao mesmo tempo, ao representar o outro como o diferente, a mídia valoriza o seu próprio lugar cultural. Ainda notamos que ao fazer a cobertura da guerra na Síria, diversos valores advindos do local de enunciação do sujeito narrador são valorizados e expandidos. 
Procuramos observar ao longo ainda do capítulo, consideramos a forma como o discurso da guerra na Síria reportado pelo jornal The New York Times está pautado numa visão americana, fazendo com que, ao narrar fatos e acontecimentos ou opinar e comentar a guerra, a mídia possa contribuir para a disseminação de valores Imperiais norte-americanos muito além das próprias fronteiras nacionais.

Até o presente, os conflitos na Síria parecem estar longe de um fim. A guerra na Síria já se estendeu muito além do período delimitado pelo corpus desse trabalho e adquiriu, com o passar dos anos, outros contornos, principalmente após a entrada do grupo Estado Islâmico no país em 2013, tornando-se o novo inimigo. Os Estados Unidos e seus aliados apoiam aos rebeldes no combate ao grupo islâmico, enquanto a Rússia continua em seu apoio ao governo Bashar, também no combate ao E.I..

Já havíamos mencionado nas análises feitas em nossa pesquisa ser essa uma preocupação americana, pois trata-se de uma região de bastante instabilidade política e religiosa. Com a entrada do grupo, a guerra se transforma e adquire valores que não estão muito distantes das análises feitas neste trabalho. Podemos mudar o objeto, mas não a forma com que percebemos o objeto; tanto a guerra como o inimigo serão delineados de maneira semelhante, e o discurso será construído de maneira semelhante. Mesmo que outras vozes possam aparecer em sua constituição, é parte da dinâmica de um projeto de soberania americana incluí-las de maneira que os princípios ideológicos não sejam atingidos.

Retomando a nossa tese proposta para esta pesquisa, a cobertura jornalística de jornais como o The New York Times reflete a expansão desse projeto hegemônico americano, tornando-se, em certa medida, um agente, independente do conflito, da guerra ou do inimigo, nacional ou internacional. Compreender essa estrutura discursiva e sua constituição ideológica é entender a existência de um projeto expansionista nacional que data da formação da nação e que vem se construindo e reinventando ao longo da história.

Esperamos que esta pesquisa possa ajudar a compreender que tanto a mídia, como todos nós, somos constituídos por discursos que constroem verdades e saberes que, ancorados em um momento histórico, obedecem a estruturas correlatas de poder. Reconhecer essas estruturas é posicionar-se criticamente com relação ao que é produzido nos discursos. Como afirma Michel Foucault (1975, p.28): "Na região mais sombria do campo político, o condenado deixa entrever a figura simétrica e invertida do rei". 


\section{REFERÊNCIAS BIBLIOGRÁFICAS}

ALTHUSSER, L. (1971/2001) Aparelhos ideológicos do Estado: nota sobre os aparelhos ideológicos do Estado. 8. ed. Rio de Janeiro: Edições Graal.

ANDERSON, B. (1983) Imagined Communities: London: Verso.

ARENDT, H. (1951/2013) As origens do totalitarismo. Rio de Janeiro: Companhia de Bolso. e-book.

ARENDT, H. (1993/2009) O que é política? 8 ed. Rio de Janeiro: Bertrand Brasil.

BAUM, M.; POTTER, P. B. K. (2008) The Relationship Between Mass Media, Public Opinion and Foreign Policy: Toward a Theoretical Synthesis. Annual Review of Political Science, v. 11, p. 39-65.

BAKHTIN, M. (Volochinov) (1929/1999) Marxismo e filosofia da linguagem. Trad. Michel Lahud e Yara F. Vieira. 9 ed. São Paulo: Hucitec.

BOURDIEU, P. (1986) "The form of Capital", in J.G. Richardson (ed) Handbookof Theory and Research for the Sociology of Education. Westport: Greenwood Press.

BOURDIEU, P. (1991) Language and Symbolic Power. Cambridge: Polity Press.

BRANCOLI, F. (2014) Primavera Árabe: praças, ruas e revoltas. São Paulo: Desatino.

BRANDÃO, H. H. N. (1991/1998). Introdução à análise do discurso. 7. ed. Campinas: Ed. da UNICAMP.

BUCCI, E. (2009) A imprensa e o dever da liberdade: a independência editorial e suas fronteiras com a indústria do entretenimento, as fontes, os governos, os 
corporativismos, o poder econômico e as ONGs. São Paulo: Contexto.

BURK, E. (1790) Reflections on the Revolution in France, editado por E.J. Payne, Everyman's Library.

CARMAGNANI, A. M. G. (1996) A argumentação e o discurso jornalístico: A questão da heterogeneidade em jornais Ingleses e Brasileiros. 1996. Tese (Doutorado em Letras) - PUC - SP, São Paulo.

CARR, E. H. (1946/2001) Vinte Anos de Crise: 1919 - 1939. São Paulo: Editora da Universidade de Brasilia.

CHARAUDEAU, P. (2005/2013) Discurso Político. 2. ed. São Paulo: Contexto.

CHARAUDEAU, P \& MAINGUENEAU. (2004) Dicionário de análise do discurso. Coord. Trad. Fabiana Komesu. São Paulo: Contexto.

CHOMSKY, N. \& SAID E. W. (1999) Acts of Agression. Policing "Rogue States". New York: Seven Stories Press.

CHOMSKY, N. (1999) Fateful triangle: The United States, Israel, and the Palestinians. $2^{\text {nd }}$ ed. Cambridge: South End Press.

. (2005) Para entender o poder: o melhor de Noam Chomsky/ Peter R. Mitchell \& John Schoeffel, organizadores. Rio de Janeiro: Bertrand Brasil.

CLARK, R. (1997) A United Nations High Commissioner for Human Rights. The Hague: Martinus Nijhoff.

COURTINE. J-J. (2006) Metamorfoses do discurso político: as derivas da fala pública. São Paulo: Claraluz.

DAVIS, E. (1921) History of The New York Times: 1851-1921. New York: The New York Times. 
DELEUZE, G. (1986/1988) Foucault. São Paulo: Brasiliense.

DREYFUS, H. L.; RABINOW, P. (1995) Michel Foucault, uma trajetória filosófica: (para além do estruturalismo e da hermenêutica). Rio de Janeiro: Forense Universitária.

ERLICH, R. W. (2014) Inside Syria : the backstory of their civil war and what the world can expect. Amherst: Prometheus Books.

FAIRCLOUGH, N. (1992/1995) Discourse and Social Change. London: Edward Arnold, 1995.

FOUCAULT, M. (1966/2000) As Palavras e as Coisas. 8 ed. São Paulo: Martins Fontes.

. (1969/2000) A arqueologia do saber. 6 ed. Rio de Janeiro: Forense.

. (1971.2004) A Ordem do Discurso. São Paulo: Edições Loyola.

(1975/2000) Vigiar e punir: nascimento da prisão. 23. ed. Petrópolis: Vozes.

FOWLER, R. (1991) Language in the News: Discourse and Ideology in the Press. London: Routledge.

GOLDING, P.; ELLIOTT, P. (2009) News Values and News Production. In: THORNHAM, S.;BASSETT, C., et al (Ed.). Media studies: a reader. 3rd. New York: New York University Press.

HALL, S. (1992/1998) A identidade cultural na pós-modernidade. 2. ed. Rio de Janeiro: DP\&A.

HALL, S. et al. (2009) The Social Production of News. In: THORNHAM, S.;BASSETT, C., et al (Ed.). Media studies: a reader 3rd. New York: New York University Press. 
HAMMER, R.; KELLNER, D. (2009) Media/ Cultural Studies. New York: Peter Lang.

HARDT, M. ; NEGRI, A. (2001) Império. Trad. de Berilo Vargas. 2. ed. Rio de Janeiro: Record.

JUNQUEIRA, M. A. (2001) Estados Unidos: a consolidação da nação. São Paulo: Contexto.

KARNAL, L. (2001) Estados Unidos: a formação da nação. São Paulo: Contexto.

LOCKE, John. (1689/2014) Segundo Tratado sobre o Governo. São Paulo: EdiPro.

MAINGUENEAU, D. (1997) Novas tendências em análise do discurso. 3 ed. Campinas: Editora da UNICAMP.

. (2002) Análise de textos de comunicação. 2 ed. São Paulo: Cortez.

NAÇÕES UNIDAS NO BRASIL. O Conselho de Segurança. ONUBR. Disponível em: https://nacoesunidas.org/conheca/como-funciona/conselho-de-segurancal Acesso em: 14 dez 2017.

ORGANIZAÇÃO DAS NAÇÕES UNIDAS (1948/2009) Declaração Universal dos Direitos Humanos. Agosto 2009. Disponível em: http://www.onu.org.br/img/2014/09/DUDH.pdf. Acesso em: 14 dez. 2017.

O'SULLIVAN J. (1845) United States Magazine and Democratic Review 17, no. 1 (July/August, 1845):5-10.].

Disponível em https://pdcrodas.webs.ull.es/anglo/OSullivanAnnexation.pdf. Acesso em 03 de janeiro de 2018.

ORLANDI, E. P. (1999/2000) Análise de discurso: princípios e procedimentos. 2. ed. Campinas: Pontes. 
PÊCHEUX, M. (1975/1997) Semântica e discurso: uma crítica à afirmação do óbvio. Campinas: Ed. da UNICAMP.

. (1983/1997) O discurso: estrutura ou acontecimento. 2. ed. Campinas: Pontes.

ROOSEVELT, T. (1889) True Americanism. In What So Proudly We Hail, Ch. 6, section A, reading 1: True Americanism (edited). Disponível em:

https://www.hudson.org/content/researchattachments/attachment/1216/theodore roo sevelt true americanism.pdf. Acesso em:14 dez 2017.

RUBIN, B. (2013) The Truth about Syria. Los Gatos: Smashwords. e-book.

SAID, E. W. (1978/2001) Orientalismo: o oriente como invenção do ocidente. Trad. de Tomás Rosa Bueno. 3 ed. São Paulo: Companhia das Letras.

. (1994) Culture and Imperialism. New York: Vintage Books.

. (1997) Covering Islam: How the media and experts determine how we see the resto of the world. New York: Vintage Books.

. (1999) Appocalypse Now. In CHOMSKY, N. \& SAID E. W. Acts of Agression. Policing "Rogue States". New York: Seven Stories Press.

. (2003) Cultura e Política. São Paulo: Boitempo.

SILVA, T. T. da. (org.). (2000) Identidade e diferença: a perspectiva dos estudos culturais. Petrópolis: Editora Vozes.

TARDE, G. (1992) A opinião e as massas. São Paulo: Martins Fontes.

THE NEW YORK TIMES. The New York Times Article Archive. Disponível em: http://www.nytimes.com/search/sitesearch. Acesso em: 10 jan 2018. 
THOMPSON, J. B. (2009) A mídia e a modernidade: uma teoria social da mídia. 11. ed. Petrópolis: Vozes.

TODOROV, T. (1970) As estruturas narrativas. São Paulo: Perspectiva.

VIDAL, G. (2002) Perpetual War for Perpetual Peace. New York: Thunder's Mouth Press.

. (2002) Dreaming War: blood for oil and the Cheney-Bush junta. New York: Thunder's Mouth Press.

WITTKOPF, E. R. (1996) What Americans really think about foreign policy. Washington: The Washington Quaterly.

WILDE, O. (1891/2014) The Soul of Man under Socialism. London: Arthur Humprey. E-book. 